UNIVERSITY OF MISSOURI COLLEGE OF AGRICULTURE AGRICULTURAL EXPERIMENT STATION

M. F. MrLler, Director

\title{
THE LAND GRANT COLLEGE MOVEMENT
}

FREDERICK B. MUMFORD

COLUMBIA, MISSOURI 


\section{FOREWORD AND ACKNOWLEDGMENT}

The author claims no special qualifications for the task here undertaken. It is true he has been associated with colleges of agriculture for fifty years as student, instructor, and dean and director. During this period he has been permitted to be an active participant in an educational movement of major importance. The land grant institutions are like all other educational institutions of college and university grade with one important exception. These institutions are peculiar in that they have in their organization a college of agriculture. It is this division with its agricultural experiment station and agricultural and home economic extension service that is chiefly responsible for the federal aid granted to the land grant college and university, as well as for the large appropriations from State legislatures. For this reason this discussion deals primarily with the college of agriculture and its divisions of agricultural research and extension.

The author has not attempted to write another history or duplicate the many excellent treatises relating to the land grant colleges and universities. These are readily available and are recommended to those who are interested in acquiring a knowledge of the purpose, plan and educational accomplishments of these institutions. Some attention is here given to the underlying philosophy of the colleges of agriculture and their influence upon the social, intellectual and economic life of rural people and the public generally. Some effort has been made to evaluate the influence of the land grant college. and university on all education.

The sources of information are generally credited in the text but the author wishes to acknowledge his indebtedness to many official publications and in particular the following:

Proceedings of the Association of Land Grant Colleges and Universities; 52 volumes.

The Land Grant College Survey, Office of Education, Washington, D. C.; 2 volumes.

History of Agricultural Education, Agricultural Research, and Agricultural Extension by A. C. True, published by the United States Department of Agriculture; 3 volumes.

Official Reports of bureaus of agriculture, and state agricultural societies.

Official Reports of the Office of Experiment Stations and Extension Services of the United States Department of Agriculture.

Annual Reports of the State Agricultural Experiment Stations and Extension Services. 


\section{CONTENTS}

Page

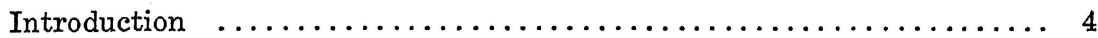

Part I. The American Land Grant College ............... 9

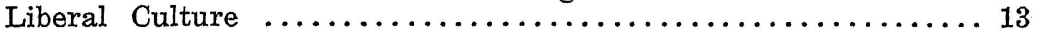

Vocational Education ............................... 14

The First Agricultural College Grant of $1862 \ldots \ldots \ldots \ldots \ldots \ldots \ldots 16$

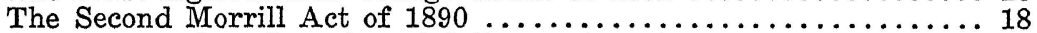

Controversy Over Location of Colleges of Agriculture and Mechanic

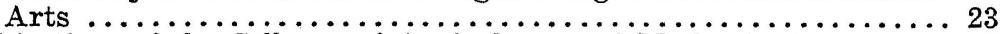

Objectives of the Colleges of Agriculture and Mechanic Arts ...... 27

Objectives as Stated by the Institutions Themselves ........... 29

Early Struggles of Land Grant Colleges ................. 32

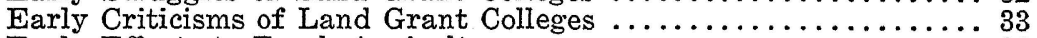

Early Efforts to Teach Agriculture ................... 36

Scope of Agricultural Training ......................... 39

The Evolution of the Agricultural Curriculum .............. 43

Part II. Development of the Land Grant Colleges .............. 53

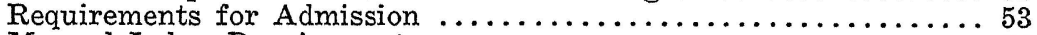

Manual Labor Requirement .......................... 54

The Agricultural Motive .......................... 57

Some Educational Influences of the Land Grant Colleges ......... 61

Measuring Land Grant College Results ................. 62

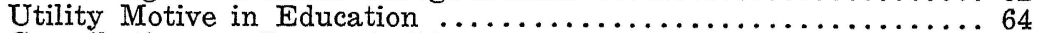

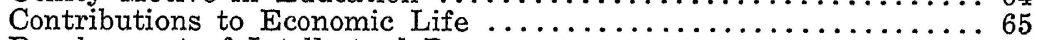

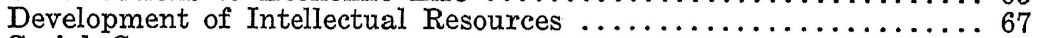

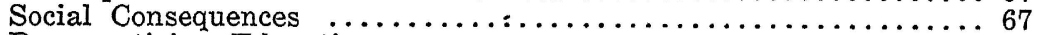

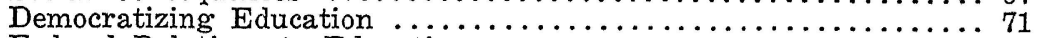

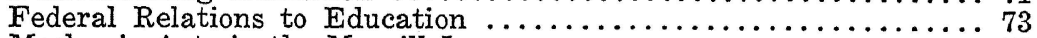

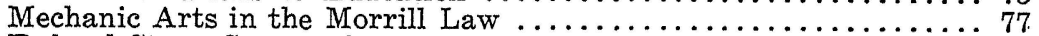

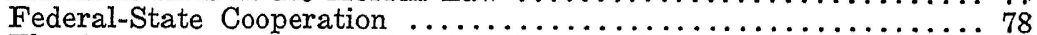

The Association of Land Grant Colleges and Universities ........... 78

Federal Laws Authorizing Appropriations for Land Grant Colleges

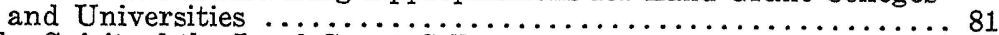

The Spirit of the Land Grant College ...................... 83

Part III. American Agricultural Experiment Stations . . . . . . . . 87

The Administration of Experiment Station Funds $\ldots \ldots \ldots \ldots \ldots \ldots 95$

The Organization of the Agricultural Experiment Station ....... 99

The Organization of Research .........................

Effective Publication of Experiment Station Work $\ldots \ldots \ldots \ldots \ldots \ldots . \ldots 104$

The Legal Purpose of Experiment Station Funds . . . . . . . . . . .

Accomplishments of Agricultural Experiment Stations . . . . . . . . 110

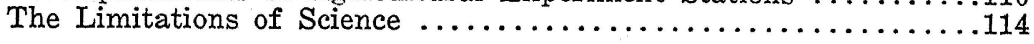

Part IV. The Agricultural Extension Service ...............117

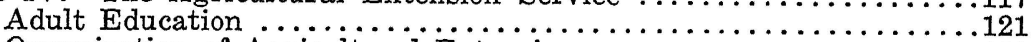

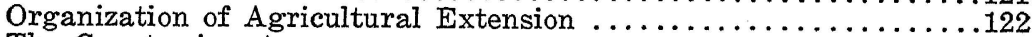

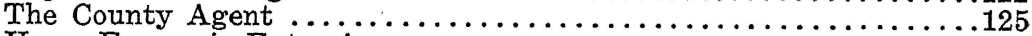

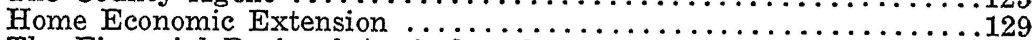

The Financial Basis of Agricultural and Home Economics Exten-

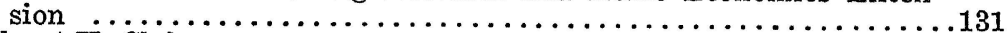

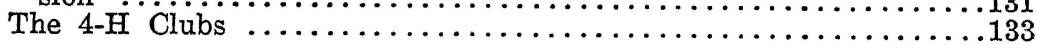

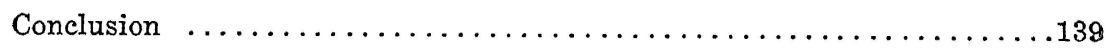




\section{INTRODUCTION}

Dean F. B. Mumford (now emeritus) has been associated with the land grant college movement for fifty years and he is one of those men who has been very influential in determining the remarkable development of these institutions. Still a member of the Executive Committee of the Association, he is exceptionally well fitted for the task of evaluating the work of these colleges. When he retired in 1938 , because of the University age limit for regular service, he undertook the preparation of a historical review of the land grant college movement and the evaluation of its contribution to American agriculture. This publication represents the first of what it is hoped will be a series he will prepare covering the field of agricultural education.

Dean Mumford was born and reared on a farm near Moscow, Michigan. He received the usual rural school education and later attended Albion College. He received both the Bachelor's and the Master's degrees from Michigan State College, that pioneer institution which has supplied so many outstanding men to agricultural college circles. Later he studied in the field of animal husbandry in the University of Leipzig and Zürich, and he has written extensively in this field.

Dean Mumford was appointed to the staff of the College of Agriculture in the University of Missouri in 1895, and has been connected with the institution since that time, holding the positions of Professor of Animal Husbandry, Acting Dean and Director, and finally Dean and Director, in which position he served from 1909 to 1938. $\mathrm{He}$ has received many honors, including the honorary degree of Doctor of Agriculture from both the University of Nebraska and Michigan State College. He has held many important positions during his service at the University. He served as Federal Food Administrator for Missouri and was Chairman of the Missouri State Council of Defense during the World War. He has been associated with many agricultural activities within the state. He has served on numerous committees in connection with the Association of Land Grant Colleges and Universities, and has been a member of the Executive Committee of that body for twenty-two years.

Dean Mumford brings to the task of evaluating the work of the land grant colleges not only a great faith in their future, but a wealth of administrative experience in the field of agricultural education and a knowledge of these institutions possessed by very few men. It is his exceptional familiarity with this entire field that makes his statements authoritative.

M. F. Miller, Dean and Director 


\section{The Land Grant College Movement}

\section{Frederick B. MUMFord, Dean and Director Emeritus}

The American land grant college has come to occupy a position of exceptional influence and popularity in our modern life. It is unique among educational institutions of the United States in its insistence upon democracy in education; its close cooperation with a basic industry; the completeness of its educational program; its reliance upon scientific research; the training of its students to prepare them for specific and practical service; its comprehensive program of adult education of a kind which is directly usable by the farmer and his family; its direct relation to government; its interest in the common affairs of life; its great contributions to the conservation of our natural resources; its recognized leadership in the progress, development, and permanent improvement of the rural population; and indirectly, but no less certainly, its contribution to the broader purpose of the public welfare. It is apparent that the land grant college is exceptional and unique among educational institutions in the United States. It has pioneered in a type of education based on human needs. It has given concreteness to the idea that education can make a very special contribution to human welfare. It has made education practical as well as ornamental. Education has been made to serve the common man. While clearly recognizing the value of knowledge and intellect, it has demonstrated that an institution of higher learning can serve directly $a$ wider group than men and women of college grade. We are forced to the conclusion that there must be certain fundamental reasons for the rapid development, continued progress, and present status of these institutions.

What are these reasons? Are these to be found in the major objectives of their educational program, the plan of organization, their federal origin, the successful cooperation of the federal and state governments or their effective administration It is certain that each of these factors has made its contribution to the widespread popularity and approval which these institutions enjoy. We shall not fully understand the land grant college of today unless we have a rather clear knowledge of the origins and forces operating to bring them into being.

The land grant college is so named from the Morrill law of Congress, approved by Abraham Lincoln in 1862. This law provided a grant of land to each state on the basis of 30,000 acres for each member of Congress. The land thus granted was to be sold and the proceeds invested in state certificates of indebtedness at 
five per cent interest. The income thus secured was to be used for the "endowment, support, and maintenance (in each state) of at least one college where the leading object shall be, without excluding other scientific and classical studies and including military tactics, to teach such branches of learning as are related to agriculture and the mechanic arts in such manner as the legislatures of the states may prescribe in order to promote the liberal and practical education of the industrial classes in the several pursuits and professions in life."

It is to be noted that the funds resulting from the sales of land are to be expended for purposes named in the law, and that these provisions must be accepted by the state legislatures. This basic provision in the first Morrill law is the constitution of the land grant college. It states with considerable clarity the broad objectives of these institutions, but it does not undertake to decide the means by which these objectives are to be attained. The bill also recognizes clearly the rights of the states in the clause which reads "in such manner as the legislatures may respectively prescribe." This would seem to give to the legislatures far greater authority in determining the actual means of reaching the major objectives than is generally known and much greater authority than any legislature has yet assumed. The legislatures of the several states have generally been content to accept the provisions of the bill, locate the institution, and then leave all educational policies to faculties of the institutions. No serious attempt has ever been made, either by the states or the federal government, to control the curriculum or to "prescribe" the specific subject matter of these institutions. This is significant in connection with the often expressed fear of federal control of education.

The land grant college is perhaps the only institution of college grade which has come into being as the result of a deep-seated and urgent demand of the common people, particularly farmers, for an education adapted to their special needs. As President W. O. Thompson said, "The point I wish to insist upon, therefore, is that this new educational reform sprang, not from the educational philosophers or the professional teachers, but from the rank and file of the people themselves." While the bill itself included provision for instruction in industrial and mechanical arts, the impetus for the passage of the bill came primarily from the farmers and those interested in the conservation and intelligent utilization of our land resources. The later history of these institutions and their relations with the federal and state governments seem to add force to the conclusion that the major influence in the progress and development of these institutions is to be found in the continuous support of farmers' organizations, farmers, farm people, and social and economic groups directly or indirectly dependent on agriculture. Every law of Congress appropriating funds for these institutions 
since the passage of the Morrill law and its subsequent amendments has been for agricultural teaching, research or agricultural extension.

It is the college of agriculture in the land grant college that distinguishes it from all other colleges and universities and gives to these federally endowed institutions their unique character and their widespread popularity. It is interesting to note in this connection that the first efforts of those interested in the promotion of agricultural education were directed toward the organization of agricultural societies or boards of agriculture. Undoubtedly, the pattern for this movement was the British Board of Agriculture, established in 1793, by act of the British Parliament. The functions of this board were to collect, print, and circulate information on agricultural subjects; to conduct agricultural experiments; to recommend to Parliament regulations necessary to promote general improvement; and to recommend outstanding discoveries of value to agriculture.

In the United States, voluntary societies were organized for agricultural improvement. In 1744, Benjamin Franklin led in the organization of the American Philosophical Society, which gave much attention to agriculture and published many articles on agricultural subjects. The interest of the members of this society led to the organization of the Philadelphia Society for promoting agriculture in 1785 . This society was apparently a group of country gentlemen and officials. Their chief purpose was to disseminate valuable information, give prizes for experiments, and especially to encourage the organization of other similar societies throughout the nation. George Washington was an honorary member of this society.

This society attempted to secure the passage of a law by the Pennsylvania Legislature providing for "a state society for the promotion of agriculture." This proposal provided that the funds appropriated might be used to endow professorships in "seminaries of learning for the purpose of teaching chemical, philosophical, and elementary parts of the theory of agriculture.

Many state agricultural societies followed these early organizations. The South Carolina Society for promoting and improving agriculture was organized in 1785 at Charleston. This society later became the Agricultural Society of South Carolina which received endowments and conducted a school for poor boys and girls at which instruction in science related to agriculture was combined with manual labor. Later this school was given to the state.

In Maine, the Kennebec Agricultural Society (1807) was first a social organization, but was also for the reading of papers and discussions.

In New York, we find that the first prospectus (1754) of King's College (afterwards Columbia College) offered courses in commerce 
and husbandry. The New York Legislature appropriated funds for professorships in Columbia College. Samuel S. Mitchell was appointed to the professorship of natural history, chemistry, and agriculture. The students in his courses were almost entirely from the School of Medicine. Mitchell seems to have had a sincere interest in agricultural education and was a member of many agricultural societies. In 1832, the New York State Agricultural Society was organized.

The motive leading to the organization of these early agricultural societies was undoubtedly education. All were concerned with essays and papers by successful farmers on many phases of agricultural enterprise. These papers were read at meetings and conferences and often published in farm papers and later official reports. The information in these was of real value to agriculture in general and to individual farmers. Together, these essays and papers constitute a most valuable contribution to the literature of agriculture. We must, I think, give substantial credit to the State Agricultural Societies for their constant efforts to provide a literature for agriculture and to develop an appreciation of the importance of knowledge and its dissemination to the development of agriculture and rural people. These societies became more and more influential with the extension of our agricultural domain. Successively these societies were organized in Massachusetts, Connecticut, New Hampshire, Virginia, and later, as we shall see, in states of the Ohio and Mississippi Valleys.

The Berkshire Agricultural Society was organized in 1811, with "ample powers but no funds," with the famous Elkanah Watson as president. Watson seems to have been the first to successfully encourage cattle shows and agricultural fairs, and he must, therefore, be given due credit for pioneering in an educational enterprise which has come to assume a very great importance in the agriculture of America. 


\section{PART I.-THE AMERICAN LAND GRANT COLLEGE}

When President Lincoln signed the Morrill Act of 1862, the United States was in the midst of a civil war. The very existence of this nation was in doubt. The passage of the Morrill Act was an act of faith-faith in our democratic institutions, faith in education, and faith in the future greatness of this nation.

There were no precedents in this field of education. The principle of government aid to higher education was new. Many of the wisest statesmen sincerely doubted the wisdom of federal grants to the states for education. There was even greater skepticism of the feasability of attempting to teach agriculture and mechanic arts in a college or university.

The first successful accomplishment of this purpose therefore is a tribute to the farsightedness of the few great statesmen who had the prophetic vision to strive through several sessions of Congress to secure the enactment of a bill establishing colleges of agriculture and mechanic arts for the express purpose of providing an education for the industrial classes. This could not have been accomplished without the strong purpose of public sentiment behind their representatives in Congress. This sentiment and purpose grew stronger and stronger as the friends of agriculture and industry came more and more to understand the real objectives of this legislation. So great was the public interest in this bill that when Congress finally voted on the Morrill bill, it carried by a vote of 32 to 7 in the Senate and by 90 to 25 in the House. In a very real sense the Morrill bill establishing land grant colleges was a genuine expression of the public will.

The growth and development of an institution must be considered in the light of the conditions and circumstances existing at the time. In 1862, the nation was still very much in the pioneer stage of development. New England had not yet been industrialized; it was still an agricultural region. The great agricultural area of the Mississippi Valley was still "new country." Such knowledge as the farmers possessed was empirical and traditional. It was handed down from generation to generation. It was based on experience. This knowledge was valuable but inadequate to a developing agriculture. The schools had not yet interested themselves in the needs of the common people. Knowledge that was taught specifically because it was useful in the common everyday affairs of life was not regarded as appropriate subject matter for institutions of higher learning. These institutions concerned themselves with what they regarded as higher things. They taught knowledge which was useful to the professions of law, medicine, theology, and scholarship. The high schools, of which there were 
few, and the academies prepared students for this kind of a college. The liberal arts colleges, widely known as "literary colleges," offered little to the farmer or artisan. They were steeped in classicism. They served well a leisure class. They represented an intellectual aristocracy. The curricula of these institutions were based chiefly on a knowledge of vanished civilizations. There was general acceptance of the idea that a knowledge of how ancient peoples had solved the difficult problems of living was the best pattern for the people of the American democracy.

It was inevitable that this philosophy should be challenged in a democracy surrounded by vast undeveloped natural resources and peopled by enterprising citizens denied accurate knowledge of the materials and forces of nature. Science was yet in its infancy. There was vast ignorance of the efficient utilization of our enormous area of agricultural lands. This ignorance extended also to minerals, to water power, and to forests, but to lesser degree.

It is to be wondered why the leaders of thought in the great educational institutions of the time failed utterly to sense this problem. What an opportunity for service to the nation was permitted to pass them by as a result of their too great an insistence on the purely classical and traditional approach to the scholarly life.

Science had little standing in the universities and colleges of 1862. In those institutions where science was first introduced, it was rather looked down upon and certainly not regarded as of equal value to the classics in the requirements for a degree. The federal government had carefully avoided any very considerable attention to education. The states had inadequately provided for public elementary schools and much more inadequately for high schools. State colleges and universities were few in number and badly supported. At first, even the state institutions followed rather blindly the educational patterns of the so-called literary colleges. At a later time the state institutions became much more responsive to the public will. True, they never have neglected the liberal arts as an educational motive, but the educational objectives of these institutions have been broadened, and side by side with colleges of liberal arts we now have colleges of agriculture and engineering, schools of journalism, education, fine arts, forestry, and commerce, as well as law and medicine. Truly today the state university and the state college serve our American democracy and represent true democracy in education.

It was under conditions such as those existing in 1862 that the land grant college was born. We have seen how to some extent, at least, it was a national protest against the idea, that a classical education was the only true education. It required an act of Congress to prove that higher education was for all and not for a privileged few. The soundness of this principle is still challenged by some. It is argued by the extreme proponents of a so-called 
liberal education that the real objective of higher education is culture. True culture by means of education is the result of a fairly well defined course of study in which certain subjects are essential. Mental discipline is essential to the development of mental power. Such discipline is the result of intense application to certain subjects. In other words, the subject matter itself is important. In general, it is argued such subjects as are included in the curriculum of a college of agriculture do not so well lend themselves to the development of true culture. Education for use is not and cannot be of the same cultural value as other subjects selected solely for their cultural value.

These arguments in support of the thesis that a liberal education is the true approach to liberal culture are to be regarded as the intellectual bases of the traditional college course. We may appropriately inquire if this is the one and only road to a liberal education.

What after all is a liberal education? Is an historical education based on tradition more liberal than one based on a wide knowledge of the social, economic and technical accomplishments of today? Perhaps we need a better definition of liberal.

In a paper before the Association of Land Grant Colleges at their Annual Conference in 1923, Dr. A. Ross Hill, former president of the University of Missouri, discussed the contribution of land grant colleges to liberal culture. In this valuable paper, he traced the conception of a liberal education to the ideal of the Greeks "as a means to the development of a free personality, a love of knowledge for its own sake, and an appreciation of the things in life most worth living for. They define the most worthy objects of a man's life-intellectual and aesthetic enjoyment, political and moral freedom, social and personal excellence." The university or college, however, as an institution is the product of the Middle Ages and the aim of these early universities was either professional or disciplinary. It was "to the Renaissance we owe the revival of the idea of a liberal education. . . which found no worthy aims or interests in this life except as they were thought to be connected with the life to come, and which looked upon college training as a mere discipline in a few restricted activities of the mind or preparation for the professions of law, medicine, and theology.

This ideal of education yielded to an education based upon traditional knowledge of the past and "appreciation of opportunities of life in the present." In accomplishing this liberal education, Latin and Greek were essential because the knowledge of the past was recorded in these classical languages. In the progress of time some made the mistake of confusing the means of education "with either the cause or the purpose of the prevailing educational point of view." Greek and Latin were merely instruments, were only a means to the study of humanities. Gradually, therefore, "merely 
a means came to be considered an end in itself; the term 'humanities' came to indicate the language and literature of the ancients and the aim of education came to be thought of in terms of languages instead of in terms of life." With the development of the sciences and many other modern subjects, there was developed a new knowledge and more and more came to be an essential part of a liberal education. Dr. Hill continued, "fundamental insight and broad application of principles are conducive alike to liberal culture and to professional efficiency." But these are the results of a scientific training. Science is the basis of all agricultural teaching. He said further, "Undoubtedly science has been dehumanized to all too great an extent in college instruction, but the teachers of agriculture and mechanic arts have not been the chief sinners. And what a wealth of opportunity these subjects present to indicate the significance of applied science in the changed human relations that are incident to this industrial age!" He further emphasized the contribution the land grant colleges have made in the development of a larger appreciation on the part of higher educational institutions for the type of public service and general diffusion of knowledge which is recognized as a function of the college of agriculture. A significant statement in this article of President Hill's is worth further quotation: "Culture is not an element that inheres in any particular form of subject matter but is a by-product of the educational process; it involves insight into and appreciation of present day conditions of human life . . . it is an attitude of mind, a philosophy of life, a point of view from which a sane criticism of life and life's values may be directed." It would be unfortunate indeed if all the new knowledge now available through the discoveries of science which have revolutionized the modern world should be denied to liberally educated scholars. The liberal arts college of 1938 itself seems to represent a revolution as compared with the earlier reliance on classicism. The subject matter requirements now included in the curriculum of the liberal arts college are very different from the subject matter requirements of the literary colleges of 1862 . These subjects bear little relation to the classical foundations of the liberal arts education of earlier days. Many subjects are now included, not primarily because of their disciplinary value, but very often because of their usefulness or because there is a very definite demand for such courses. The much larger inclusion of science courses suggests that science has become a subject of real cultural significance. It is a well known fact that the basis of the training in a college of agriculture is science. Even so-called agricultural courses have developed to a point where they themselves are science courses and we may look forward to a time, perhaps, when better teaching, better organization of subject matter, and still further scientific discoveries, when the so-called practical or technical courses in agriculture may admittedly have cultural 
value approaching many courses now offered for the bachelor of arts degree.

Higher education in a democracy cannot be denied to all who may profit from its pursuit. All should not follow the same course or be educated in the same field. As Dr. Chas. W. Dabney remarks, "The harmonious and equitable evolution of man does not mean that every man must be educated just like his fellow. . . . That community is most highly educated in which each individual has attained the maximum of his possibilities in the direction of his peculiar talents and opportunities."

The land grant colleges were successful in demonstrating the value of higher education to the common people. They are in large part responsible for establishing the now recognized fact that a college education is possible and desirable for many different classes of people. They have successfully challenged the thesis that a college education is for the select few.

There is abundant evidence to show that liberal arts colleges are becoming more useful and even vocational and that the colleges of agriculture are recognizing the importance of certain subject matters of recognized cultural value.

\section{LIBERAL CULTURE}

It is no part of this discussion to attempt an appraisal of the great contributions of the liberal arts college to our civilization. Their insistance upon the highest standards in scholarship, their appreciation of the esthetic values of education, their appreciation of the value of a rigorous intellectual discipline, all have contributed to the high achievements of these institutions of higher learning. It goes without saying that they have for generations represented the bulwark of advanced scholarship and culture, but the character of this group has greatly changed. Their objectives likewise seem to have been profoundly influenced by modern life. They served well, but they served comparatively small numbers in our population who were able and willing to accept liberal culture as the most important motive. It is to be observed that education of the nation's youth is an enterprise so great and of such fundamental importance to the welfare of the nation that it should not be limited to a small group in our modern life.

Education adapted to modern needs has proved its worth. There are programs of education of the greatest value in training youths for the lives they must lead. Admittedly, highly technical and specialized types of education leave little room for education in the humanities. This is not to say that such education would not be desirable. There is no one kind of education best for all kinds of people. There is no basis for the idea that education should be limited to a small select group in our democracy. There is no real basis for the assumption that the leaders of our national life 
should be trained in a liberal arts college. This is an industrial age. It does not seem probable that leaders in agriculture, in engineering, in medicine, in law, or in business and public administration would be able to lead without the knowledge provided in special colleges for the preparation of such leaders.

Fundamentally our American democracy is dependent upon education. There may $b s$ a difference of opinion as to the kind of education which our citizens should receive, but clearly any education that increases the efficiency of American citizens is desirable. Any education dependent upon public sentiment as represented by the appropriating bodies must in some manner prove its worth. It is this latter element that has made the land grant college movement in the United States what it is. No type of institution of college grade has been more generously supported by the federal and state governments than have the colleges of agriculture. They have been so supported because of the demonstrated value of their educational program in our American democracy. There is no apparent, immediate intention on the part of the federal and state governments to discourage the further development of these institutions.

No one can deny that a knowledge of history, economics, philosophy and logic, and humanities generally is of great value to any man. They would be of great value to students in colleges of agriculture. There is some movement in that direction now. It should be encouraged.

\section{VOCATIONAL EDUCATION}

Some educational leaders of influence in the councils of higher education regard the institutions teaching agriculture and mechanic arts as of a lower order. These institutions are vocational. They may be useful, but because they are purposeful and because the materials of instruction are the common, the ordinary, the everyday phenomena affecting and controlling all industry and human life itself, they are not to be placed in the same category as the study of purely abstract problems and the exercise of the contemplative mind. After all, according to this educational philosophy, the growth and development of mental power is a sufficient end in itself, and this has been best accomplished in the past by the traditional type of education. It does not seem to the writer that this attempt to put these institutions in their place has been very successful. All education is, in a sense, vocational. Even under the older system, students have always looked forward to the professions of law, medicine, or theology. The error is in thinking that these so-called learned professions are the only ones entitled to a kind of higher education which prepares them for leadership. It is perfectly true that in the past leaders of our national life have 
been products of the traditional education. But is this true today? Even so, the greater number of leaders that came from these institutions in the past is explainable for the reason that they were the only institutions of high degree available.

Leadership in our national life today is quite as likely to be found among the products of the land grant colleges and universities. Perhaps these institutions today furnish a majority of our leaders of industry, commerce, agriculture, and statesmanship. No one for this reason would attempt to depreciate the great accomplishments or present values of a liberal arts education. The land grant college claims no monopoly of education, on the other hand admits no monopoly of others.

The graduate school is the highest expression of the spirit and purpose of the American college and university. It is organized and administered to encourage and promote the highest ideals of scholarship and intellectual attainment. We should then find in this division of the higher institutions of learning the very best in education-the culmination of our ideals and the ultimate accomplishment of our educational purposes. If these things be true, all institutions of college and university grade must, in large measure, formulate their ideals and build their educational philosophies on the advanced thinking of the graduate school.

The ultimate objectives of the graduate school are, after all, the objectives of the undergraduate college except that they are on a higher level and accompanied by appropriate method. Broadly speaking, the purpose of the graduate school is the advancement of knowledge. This is the purpose of the undergraduate college. This is the purpose of all institutions of college grade.

The modern graduate school now organized in every great university in this country must labor under the onus, if onus it be, of being a division primarily concerned with preparing men and women for useful vocations. The graduate school encourages the highest types of university study for improving the professional equipment of teachers, for the higher training of men and women for research in the fields of chemistry, physics, biology, mathematics, agriculture, engineering and for every other field of intellectual enterprise in which high intellectual attainments are required. Most graduate students now are in training for some special vocation. Very few are registered in the graduate school for the sole joy of intellectual attainment. It cannot, therefore, be successfully maintained that vocational training is of a lower order if, as it seems, our highest of all university efforts as represented by the graduate school is itself a type of vocational training. 


\section{THE FIRST AGRICULTURAL COLLEGE GRANT OF 1862}

The first bill ever introduced in the federal Congress for the establishment of colleges of agriculture and mechanic arts was introduced in the House of Representatives by Mr. Justin S. Morrill of Vermont on December 14, 1857. He was undoubtedly influenced by what he stated was a literal bombardment of petitions "from the various states north and south, state societies, county societies, and individuals." In his argument for this bill he maintained that "all direct encouragement to agriculture has been rigidly withheld." He continued his argument by maintaining that "farmers and mechanics require special schools and appropriate literature quite as much as any one of the so-called learned professions. . . . It is plainly an indication that education is taking a step in advance when public sentiment begins to demand that the faculties of young men shall be trained with some reference to the vocation to which they are to be devoted through life."

These observations of Mr. Morrill as to what should constitute the subject matter and educational objectives of the land grant colleges are interesting for the reason that at a later discussion there was to develop the opinion among members of Congress that, after all, these institutions, while called agricultural colleges, should in fact be primarily "literary colleges" in which would be offered lectures on agriculture.

Mr. Morrill's vision of the ultimate accomplishments of these institutions may be regarded as somewhat optimistic, if not romantic. $\mathrm{He}$ argues, first, that agriculturists are industrious and frugal. "Thrift is their cardinal virtue. They hasten slowly but when the crisis comes all eyes turn to the hard tillers of the soil for relief." of the training to be given in these institutions he says: "Muscles hardened by such training would not become soft in summer or torpid in winter, and the graduates would know how to sustain American institutions with American vision." In this latter statement $\mathrm{Mr}$. Morrill was but giving expression to what seemed to be a general sentiment in reference to the program of education required of these students, namely, that they should perform manual labor in connection with their studies of the theory (so-called) of agriculture. The establishment of these institutions would result, according to $\mathrm{Mr}$. Morrill, in something for every owner of land, something for scientific education, something to induce fathers, sons and daughters to settle around the old homestead, something to remove the last vestige of pauperism from our land. The success of these institutions would even enable sterile railroads to pay dividends, and finally to increase the loveliness of the American landscape. Truly, the land grant college was to become a wonder-working institution. Perhaps of no group of educational institutions ever established in this country was more expected.

Throughout the entire discussion in Congress of the original Morrill Act great emphasis was placed on "doing something for the farmer." 
The argument was that manufacturers had been protected by high tariffs, transporation companies had been subsidized with enormous grants of land, and efficient schools were available for lawyers, doctors, preachers and teachers; but no institutions were devoting any attention to the special requirements of the farmer and his family.

The original bill was finally passed in the House of Representatives by a close vote. It was later presented in the Senate and eventually failed of adoption during that session. During the second session of the Thirty-Fifth Congress the bill, having passed through many legislative vicissitudes, passed the Senate by a vote of 25 to 22 . There is little evidence in the proceedings reported in the Congressional Record that the educational features of this bill received much attention. The chief argument seemed to revolve about the question as to whether or not the federal Congress had a constitutional right to grant lands for this purpose. Even so, it was unwise to dissipate the public domain in such manner. Certain members of Congress feared that the bill would injure existing institutions. Various other plans for subsidizing education were discussed, some insisting that this amount of money would do the country more good if expended for common school education. Others were very skeptical of the benefits of a college education for the agricultural classes.

The bill passed by Congress reached President Buchanan in February 1859, and was vetoed. The President insisted that the plan was financially inexpedient, that such a large grant of land at one time would result in demoralizing land values, that the passage of the bill established a dangerous precedent and opened the door to all sorts of raids on the federal treasury for educational and other purposes. He believed that the bill would interfere in some way with the rapid settlement of unoccupied lands, that it would injure existing colleges, and finally, he thought the bill was unconstitutional.

When the veto message was returned to Congress, Mr. Morrill made a brave effort to secure the passage of the bill over the President's veto, but the two-thirds majority required was not secured and the bill did not become a law. This ended all chances for grants to establish agricultural colleges in the Thirty-fifth and Thirty-sixth Congresses. There seemed no hope of favorable legislation so long as $\mathrm{Mr}$. Buchanan was president.

But in 1861, a new administration gave encouragement to the friends of agriculture to renew their efforts, and on December 9, 1861, Mr. Morrill gave notice to the House of Representatives that he would introduce a bill donating lands to establish colleges for the benefit of agriculture and mechanic arts. A similar bill had been introduced in the Senate. It had received the only favorable committee report yet made on any one of the agricultural college land-grant bills. The bill was finally passed by both the Senate and the House, and on July 2, 1862, President Lincoln approved the Land Grant College Act which established the Land Grant College as a federal institution. Senator 
Morrill said of this legislation, "The most valuable direct favor the government has ever bestowed upon agriculture and the mechanic arts was unquestionably the endowment of the so-called agricultural colleges." The United States Bureau of Education in a circular of information, 1888, "The History of Federal State Aid to Higher Education" stated that "next to the ordinance of 1787 the Congressional Act of 1862 is the most important educational enactment in America."

In is interesting to note that Senator Morrill's proposal to provide separate colleges of agriculture and mechanic arts was not the only proposal for agricultural education under federal jurisdiction. On December 5, 1854, the Honorable Mr. Wentworth of Illinois offered the following resolution in the House of Representatives: "Resolved, That the committee on agriculture inquire into the expediency of establishing a national agricultural school upon the same principle with the national naval and military schools, to have one scholar, educated at the public expense from each Congressional district and to be established in connection with the Smithsonian institution so as the better to carry out the object of its founder."

\section{THE SECOND MORRILL ACT OF 1890}

During the consideration of the first Morrill Act of 1862, in the arguments of members of Congress, the fear was often expressed that the grants of public land for education would result in further demands on the government for more funds, not only for agriculture and mechanic arts education, but for other and perhaps less worthy educational projects. These fears seem to have been justified, for in 1872, Mr. Morrill himself, now a Senator, introduced a new bill (S-693) providing for additional funds for the further endowment and support of colleges of agriculture and mechanic arts which had been organized in most of the states under the provisions of the law of 1862. The bill had the unanimous support of a convention called by the commissioner of agriculture and was described by Senator Morrill as "a convention of high character and hardly ever surpassed in this country for their intelligence." This convention was composed chiefly of delegates from agricultural colleges and agricultural and horticultural societies. The continuing argument in connection with all early land grant college appropriations as to whether chief emphasis should be placed on "literary or mainly scientific" training was again in the foreground of discussion. In this connection Senator Morrill made one of the few pronouncements on the kind of education which should engage the major efforts of these institutions.

"It was clearly intended," said Senator Morrill, "that these national colleges should place scientific or practical studies foremost as the leading object, and whatever else might be added, that these were in no case to lag in the rear. Knowledge not for use may do for useless philosophers, . . . but here education embracing the largest num- 
bers must have such scope as to practically fit the owner for his destined vocation. Its backbone will be made up with what will be most needed. . . . The classical tradition accepted in this country and adopted in the main from our English inheritance was not the only education possible or necessarily of most value. Are we never to create anything," he asks, "and so remain forever hopelessly in debt to ancient languages? . . . We want a system of broader education for the American people in the arts of peace, and especially in agriculture and the mechanic arts."

These words of Senator Morrill have often been quoted and have undoubtedly had a material influence, not only on the general trend of development in these colleges, but to some extent upon the subject matter of chief concern in these institutions. He emphasizes the national character of these schools and their value to the national welfare. They are, it is true, to be state schools with a high degree of autonomy, but at the same time their success is of real concern to the nation. They are national, not only because they are established and endowed by the federal government, but because from their very purpose and nature, certain to promote the general welfare.

He places great emphasis on the fact that these colleges are to teach practical subjects which are "needed." This idea has in it the suggestion of some modern educators who declare that we should first determine what kind of an education is needed and then adapt instruction to these needs. It is also interesting in view of the later expansion of agricultural colleges to note that while no direct provision was made in the original law for scientific research, nevertheless one of the purposes declared by Senator Morrill was scientific research and through research the creation of new knowledge.

One of the arguments for this bill is interesting in the light of often repeated criticisms of colleges of agriculture because their type of education is too "narrow". Senator Morrill, in arguing for the passage of the act of 1890 , says, "But we want a system of broader education . . . for the arts of peace, especially in agriculture and mechanic arts." The inference here seems to be that the prevailing literary education was itself too narrow for American youth.

The terms used by educators need more precise definition. Is it broadening education to include new subjects in the curriculum? What is a narrow education? Is it quite correct to limit the term liberal education only to the traditional, historical, and classical motives of the past? Is a classical education, after all, more liberal than an education based on the newer knowledge of modern events? We cannot ignore the fact that the knowledge we live by today is new knowledge. If education is primarily to develop our mental powers of judgment, accurate observation, and ability to think, may it not be true that these qualities of mind may be developed by a technical curriculum? After all, no single type of education is or can be perfect or complete. Each has its limitations and each has its values. 
Continuing his arguments for the bill, Senator Morrill closed with the prophetic statement that "a great part of the legislative work accomplishes its utmost purpose and is obsolete at the end of the year, but here is work that we may fondly hope will endure for ages. There will be no immediate splendor, but a spark will be lighted which may illumine the whole land and lift a cloud from the pathway of the sons of toil, . . . that will open to them higher spheres of service and honor, give to republican institutions a more enlightened and enduring support, and make a nation which shall not only desire to live, but deserve to be immortal."

Many of these prophecies seem to have come true. Rural affairs have assumed a new dignity and importance as a direct result of the work of these institutions. But in 1890 there were arguments in opposition to such substantial appropriations for this purpose. The land grant colleges during the first twenty-five years of their existence, at least from the standpoint of their services to agriculture and rural people, must be regarded as of limited value. The fond hopes of their founders had not been fulfilled. They satisfied neither the administrators nor the farmers. The general opinion of the time, as expressed in farm papers and in the proceedings of agricultural societies and boards of agriculture, was very critical. It is not strange, therefore, that a member of Congress should have dubbed these institutions "lame ducks." The arguments opposing this second Morrill bill may be briefly summarized.

The expenditure proposed in view of the condition of the revenues was unwise; if the appropriation was made, it should be allocated on the basis of population and not an equal amount to each state; it was not logical to build an agricultural college in mining states or commercial states or banking states; and, worse than all other considerations, this bill was but an entering wedge for a national system of education which would conflict directly with the rights of the states to manage their own affairs. One congressman called attention to a discrepancy in this bill compared to the original Morrill Act which seemed to definitely increase the federal authority and supervision as compared with the Morrill Act of 1862. Senator Reagan argued that, "It seems to me the purpose of the bill is to fix upon our legislation the principles that Congress is to go into the states, take charge of educational institutions, and regulate what is to be done with them. . . . It seems to me that the Senator from Vermont might have contented himself by letting this appropriation be made under the terms of the original law making appropriations for the benefit of agricultural colleges, but it appears that that does not satisfy him; he must go further, extend the powers of the Federal Government . . . and give supervision over this branch of schools to the officers of the Federal Government under rules which they may adopt." Senator Morrill then replied that the change in the bill was more definitely to insure that these institutions should devote 
themselves to the real purposes for which they were established. "I cannot see that the objection . . . ought to have any weight here. Of course, if we make this appropriation, the government ought to be assured that it is to be applied and spent in the manner expected and provided." Continuing, the Senator explained that, "I will say that some of the institutions are represented as not giving sufficient attention to the agricultural and mechanical parts of their studies; that they do not give them the lead, and this provision has been inserted in order to insure that they shall be so devoted."

In the light of present-day efforts to secure federal funds for education in the states without federal administration, this is an exceedingly interesting and illuminating discussion of the subject of federal control of education. Is it possible or wise for the Federal Government to appropriate funds for education or any other purpose and not administer or supervise and to some extent regulate (or control) the expenditures?

This discussion is interesting also as evidence of the more or less general opinion that these institutions had not really succeeded in making agriculture and mechanic arts the "leading object" in their educational programs. Seventy-five years after the founding of these institutions and in the light of history, we now know that Senator Morrill's statement was essentially correct, and, whether due to this statement or combined with other causes, the colleges of agriculture really began to teach agriculture and to serve farm people, and as a consequence experienced a period of almost unexampled prosperity and influence.

The second Morrill Act differs somewhat from the first in respect to the purposes for which the money was to be expended. The first Morrill Act stipulated that the federal funds should be used for "the endowment, support, and maintenance of at least one college where the leading object shall be, without excluding other scientific and classical studies, and including military tactics, to teach such branches of learning as are related to agriculture and the mechanic arts." The second Morrill Act is much more specific. The latter act required that the federal funds shall "be applied only to instruction in agriculture, the mechanic arts, the English language, and the various branches of mathematical, physical, natural, and economical sciences, with special reference to their applications in the industries of life."

The language of the second Morrill Act seems to have been influenced by a more or less general opinion, especially among farmers and rural people, that these colleges of agriculture and mechanic arts had not somehow been organized and administered in the spirit of the original enactment. Some institutions were not teaching classical subjects, the languages and sciences with "special reference to their applications in the industries of life." During the debate on this bill in the House of Representatives, Congressman Anderson of Kansas, who said he had served five years as President of the Kansas 
Agricultural College, remarked that, "during the first half of the period since the agricultural grant. was made in 1862, the colleges organized under it were entirely and naturally devoted to the professional curriculum and necessarily turned out lawyers, doctors, preachers, and teachers. During the latter half of the period the agricultural colleges, finding that they were not giving a satisfactory education to the farmers, devised a curriculum for the purpose of affording specific technical knowledge, and the object of this bill is to cause these colleges which have been absorbed by professional educators . . . to adopt and apply a modern curriculum applicable to the mechanic arts and agriculture alone."

We may not agree with everything included in the remarks of Congressman Anderson, but he did give expression to a widely held impression that the so-called agricultural colleges were not successfully accomplishing the purposes which many persons had fondly hoped might result from their establishment. There was frequent criticism in the agricultural press, in the official reports of agricultural and horticultural societies, and of boards of agriculture. It was openly charged that the instruction offered was theoretical and not practical.

The Morrill laws and later amendments and Section 22 of the Bankhead-Jones Act provided funds for resident teaching only. These appropriations cannot be used for research or for extension. 


\section{CONTROVERSY OVER LOCATION OF COLLEGES OF AGRICULTURE AND MECHANIC ARTS}

After the passage of the Morrill Act in 1862, one provision of the law required that the land grants should be accepted by the legislatures of the several states and that these legislatures should locate the colleges of agriculture. The location of these institutions aroused widespread interest and eventually became more or less of a national controversy.

The administrators of established institutions saw in the federal grant of lands, involving millions of acres, a possible addition to their endowments, since the law was clear in stating that the funds could be used for teaching other subjects than agriculture and mechanic arts. Such subjects were being taught in established institutions and were, therefore, already available to students.

On the other hand farmers almost unanimously opposed the joining of colleges of agriculture and mechanic arts with established institutions. They argued that Congress clearly intended to establish separate colleges of agriculture. The so-called literary colleges of the day had existed for a long time and had rendered no service to agriculture and mechanic arts. It was not probable that the environment found in such institutions would be favorable for the development of colleges for the industrial classes. There was abundant evidence, so argued these farmers, that the educational philosophy motivating literary colleges was fundamentally opposed to the idea of teaching such common and ordinary subjects as agriculture and mechanic arts. The farmer insisted that these institutions must be so organized and administered as to serve the farmer's interest first. Agriculture should not be a mere appendage to literary colleges, where a few lectures on the subject would be given, but agriculture and mechanic arts must be the leading object. If these colleges were located with the classical or literary institutions already established, the subject of agriculture and mechanic arts would be subordinated. After all, these institutions had never shown any interest in the problems of the industrial classes and it was not probable that even with added funds they would suddenly develop a primary interest in this type of education.

There were a few voices suggesting some sort of a compromise. Judge French, writing in "The Country Gentleman" in 1864, suggested "between a union with other colleges and the entire independence of them lies a middle course . . . locating the college of agriculture a distance of a few miles from an existing college will obviate all the objections to an intimate union and yet not exclude many of the advantages claimed for such an association." In the first annual report of the Missouri State Board of Agriculture for 1865 the secretary's report, which seems to have had the unanimous approval of the membership in a discussion on the general subject of the location 
of an agricultural college, remarks, "It must be deemed unwise and inexpedient to incorporate the industrial college with any existing literary institution . . . because a liability would, in such case, be incurred of an overshadowing influence from, or an ultimate absorption into the institution to which it is attached." Another compromise, which was similar to the one proposed by Judge French, was to have the college of agriculture and mechanic arts located on the same campus but under a different management. Quoting from the same Missouri report of 1865, the secretary continues, "If Columbia is deemed the best location of the industrial college on account of the advantage of the State University or any other advantage, let it be so located but let the organization, government and control of the industrial school be independent of the other. . . . The industrial classes of Missouri will never be satisfied to have their college attached to a literary institution." In the same report the author continues, "Agriculturists have found, after laboring a score of years to obtain it, that they have a most arduous task to perform in preventing it from being absorbed by existing literary institutions, or so divided up as to be nearly worthless or otherwise frittered away or diverted from its legitimate purpose."

So the controversy continued, being chiefly concerned with the question as to whether or not it was wiser to locate the college of agriculture and mechanic arts as a division or department of an existing institution or to establish an entirely separate and independent college where there could never be any doubt about agriculture and mechanic arts being the leading object of the institution.

Another factor entering into the decision as to the location of these institutions was the question of environment. Many argued that these institutions should be located in the best agricultural regions where the land was of high fertility and agriculture was prosperous and successful. Others quite as vociferously argued that such localities: were less in need of a college of agriculture than those regions having a soil of low fertility and a farming population that could not be said to be prosperous. "E. H." from Champaign County, Illinois, argues. in "The Country Gentleman" of 1865 that the state agricultural college should be located near Chicago. His reasons are that no other area in the state has "such a body of swamp and overflowed lands calling. for reclamation and demanding all the skill of a college agricultural staff to make productive of anything but potatoes and cabbages." $\mathrm{He}$ argues further that because of the vast quantity of manure, accumulated presumably in the stock yards, this condition should "lay the foundation of a model farm." Presumably, he may have had in mind other advantages from locating an industrial institution near a great city, but if so, he failed to state them.

At the time the problem of locating the colleges of agriculture and mechanic arts was before the various legislatures of the states, the question of whether or not to locate one institution or several was considered in many states. In Connecticut, for example, Francis. 
Gillette in the report of the Connecticut Board of Agriculture for 1866 . remarks, "We want agricultural schools, one in each county of the state."

The Missouri State Board of Agriculture in its report for 1865 . records its opinion that, "The object contemplated by Congress in the act of donating lands was beyond a shadow of a doubt the establishment of independent colleges. If it had been the object of the grant to increase or extend the facilities for instruction in any of the existing literary institutions it would undoubtedly have been so stated. The language of the act plainly specifies a different purpose." On December 29, 1865 the Missouri State Board of Agriculture adopted among other resolutions the following: "the college should not be incorporated with existing literary institutions of the state. The management should properly be placed in the hands of the industrial classes. In 1866 the Missouri Legislature considered a bill introduced, which would provide for the location of four colleges: another proposal was to locate two; one north and one south of the river. At the same time a proposal to locate the new college in Columbia was given consideration but all these proposals were defeated. As representing the arguments in favor of locating the college of agriculture as a division of the University of Missouri, the Board of Curators presented the following arguments: It would fulfill the requirements set by the grant; complete the idea of the university; make the institution more directly and extensively useful to the whole of the state; minimize expenses, and make it possible to start work at once. Literary instruction was already given in the university and, it would be easier, the curators said, to establish the college of agriculture in connection with the university than to attempt to organize an entirely separate and independent institution.

In connection with the location of the Missouri institution, "Coleman's Rural World" expressed its preference for a separate and distinct college but "rather than see such an institution linger and languish . . . we should favor a plan giving it a connection with an existing institution, giving it two or three practical men as professors, and establishing a connected yet separate school." It seemed to be also the opinion of friends of agricultural education in Ohio that there should be established a separate institution. In the twentysecond annual report of the Ohio State Board of Agriculture for 1867, Judge Jones then remarked upon the proposed character of the college conducted with especial reference to the wants of farmers and insisting that it should be distinct from any existing institution and mechanics.

It must be remembered that in connection with this whole controversy, the provisions of the Morrill law itself had much to do with the decision as to whether the colleges of agriculture should be institutions of general culture or more specifically technical colleges. The provisions of the law clearly were permissive in respect to all the subjects taught in literary colleges. However, the law was specific 
in stating that the leading object should be instruction in agriculture and the mechanic arts. It must also be remembered that all the leading educators in 1862 were graduates of literary colleges. They thought of education in terms of classical, mathematical, and humanistic subjects. They had no experience with or sympathy for education in agriculture and mechanic arts given for the purpose of improving the ability of farmers and mechanics. So in the nation, as a whole, we find colleges of agriculture and mechanic arts organized and administered as separate or independent colleges and almost an equal or larger number associated with state universities.

The records of achievement of these institutions for the first twentyfive years of their existence seem to give weight to the contention of the friends of agricultural education that the colleges associated with universities would not completely accomplish the purpose of the original Morrill Act. The separate colleges of agriculture during the first quarter century of the existence of land grant colleges, undoubtedly, made far greater progress and rendered a greater service to the farmers and farm people than did the colleges of agriculture associated with universities. All honor and credit should be given to the separate college of agriculture for their leadership in the field of agricultural education in the early years. However, the state universities could not long resist the continued demand of farmers and friends of agricultural education for organizing an adequate program for agricultural education; so that today, 1940, we find some of the greatest colleges of agriculture associated with some of the great state universities. There colleges are apparently serving farm people efficiently and satisfactorily. These colleges, associated with the universities and the independent state colleges together, constitute one of the most effective educational agencies in America.

The acceptance by the several states of the provisions of the original land grant of 1862 was described by Dr. A. C. True in his "History of Agricultural Education" as follows:

"Iowa accepted the provision of the Morrill Land Grant Act on September 11, 1862, and was followed by Vermont on October 29 and Connecticut on December 24 of that year. Fourteen States accepted it in 1863, 2 in 1864, 1 in 1865, 6 in 1866, 4 in 1867, 3 in 1868, 1 in 1869, and 2 in 1870, making 36 in 9 years. During that period 35 institutions received its benefits by action of the State legislatures; 15 were colleges and 20 were universities at that time or later developed into universities. In Connecticut, Mississippi, North Carolina, South Carolina, and Rhode Island the use of the land-grant funds was finally taken away from the universities and given to a separate college. In Delaware, Florida, Maine, Maryland, New Hampshire, and Ohio colleges were first given the land grant and afterwards became universities. In 9 states the land grant was given to 2 colleges and 7 universities wholly or partly on a private foundation and in 10 states to publicly supported colkeges, which had more than an agricultural curriculum 
and were often designated agricultural and mechanical colleges. Massachusetts divided the fund between the Massachusetts Agricultural College and the Massachusetts Institute of Technology."

Colleges for negroes in Virginia, Mississippi, and South Carolina received a portion of the land-grant fund.

\section{OBJECTIVES OF THE COLLEGES OF AGRICULTURE AND MECHANIC ARTS}

What kind of an institution, after all, was envisaged by the founders of the colleges of agriculture and mechanic arts? What was hoped to be accomplished by these institutions? After the location of these universities by the legislatures of the several states, the administrators appointed to accomplish the purposes of the Act were immediately confronted by the necessity of attempting to determine what were the real objectives contemplated by the Morrill law. It is true, they had the provisions of the law itself to guide them. They had, moreover, the discussions of Congress. They were familar with the expressed opinion of farmers as to what they hoped might result from the establishment of these colleges. There were various ideas expressed by experienced educators. These opinions were not always in agreement. There was not, in the beginning, any standard which could be utilized for perfecting the organization and administration of these institutions.

Educators, in general, seemed to be agreed that what the farmer needed, was an education. The education that he needed was the kind of literary education with which they were familiar. The farmer, on the other hand, wanted an education that would help him solve his problems on the farm. It was perfectly clear that Congress had in mind a kind of education that would be useful particularly to the industrial classes. These colleges were to be based on the needs of rural people. The utility motive was to be strongly emphasized. From the beginning, greater interest seemed to revolve around the teaching of agriculture. Among people representing the industrial group, there was no great enthusiasm for instruction in mechanic arts. It is apparent, therefore, from the records and discussions that the founders were thinking in terms of agricultural education rather than education for mechanics.

The author of the bill in Congress, Senator Morrill, on various occasions expressed his opinion as to the real objectives of this important legislation. On one occassion he said, "We need to test the natural capability of soils and the power of different fertilizers and the relative value of different grasses for flesh, fat, and milk giving purposes; the comparative value of grain, roots, and hay for wintering stock; the value of a bushel of corn, peas, carrots, potatoes, or turnips, in pounds of beef, pork, or mutton; deep plowing as well as draining; vitality and deterioration of seeds, etc." And he continues, "The graduates would know how to sustain American institutions with American vigor." Senator Harlan of Iowa expressed the desire 
to see the intellect of the man who sweats cultivated so that "he could be represented in this Senate by one of his own kind."

As conceived by Dr. Arthur J. Klein in charge of the survey of these institutions by the Federal Office of Education: "It was one of the purposes of the Morrill Act to set up beside and in contrast with these classical institutions another type of higher education which should emphasize the sciences and their practical application."

These institutions were to be creative. They were to create new knowledge in the broad field of agriculture. They were not to ignore all the values inherent in traditional knowledge but they were actually, through research and investigation, to solve the problems of agriculture and rural life. In so doing they would create an entirely new body of knowledge and this knowledge would accomplish the major objectives of the founders.

There is sufficient evidence that the administrators of these institutions in the early years of their existence were sincere in their efforts to accomplish the general purposes and objectives contemplated by the friends of this type of education. It is, however, always to be remembered that in 1862 the subject matter of agriculture had not been organized, systematized, and put in teachable form. There was no adequate literature of agriculture. The methods and practices of agriculture were based upon experience and the early teachers of agriculture were hard put to it to develop the kind of courses contemplated by the founders and desired by farm people.

There was even disagreement as to the grade or level upon which these institutions should be organized. This too in the face of the federal law which explicitly provided for institutions of college grade. So revolutionary was the idea of a college of agriculture and mechanic arts that the then leaders in college education were unprepared and unwilling to accept it. After all, they argued, this can only be a trade school and, while such schools are very well in their place, they are not colleges. So in the beginning these schools were not organized in such manner as to be co-equal with standard colleges in requirements for admission or graduation. While they carried the designation of "colleges" they were, after all, of little higher grade than our present high schools. They represented a compromise in educational administration. Students of limited preparation were admitted. The same high standards of scholarship required in a standard college could not be maintained with such students.

For these reasons the colleges of agriculture for many years were looked upon by the leaders in college education as institutions of a lower order. As time progressed these colleges of agriculture raised their requirements for admission, strengthened their curricula and became real standard colleges in fact and in truth. These advances in the progress of these institutions sometimes came slowly and in each state were closely related to the increased number and efficiency of the public high schools and the general rise in the intellectual level of 
rural people. Today the Land Grant College is clearly a standard college providing a rigorous training in science and its applications.

While this is true there are many educators of the old school who still look upon the colleges of agriculture with a certain degree of condescension. They are not liberal arts colleges; therefore, they are of a lower order. This prejudice is not confined to colleges of agriculture but is a general "viewing with alarm" the widespread and rapid changes in all education in the direction of education for use. The very rapid increase in the enrollment of colleges of agriculture in recent years and the widespread public approval of their educational program is evidence of their essential values in our educational system.

\section{OBJECTIVES AS STATED BY THE INSTITUTIONS THEMSELVES}

The provisions of the first Morrill Act were clear as to the broad objectives of the colleges of agriculture and mechanic arts, but not so clear as to the means for obtaining these objectives. It was to be left to the administrators of these institutions to determine how the purposes of the Act were to be realized. There was substantial difference of opinion among the educators of the day as to the means to be employed in providing higher education for the industrial classes. The law was very specific in requiring that the leading object should be the teaching of agriculture and mechanic arts. But it also clearly provided that classical and other studies were not to be excluded. Hence we find on the one hand a considerable group insisting that large attention should be paid strictly to agricultural and mechanic arts subject matter. This attitude undoubtedly reflected the opinion of farmers and friends of agricultural education. On the other hand, there was a considerable group who insisted that after all education as then understood with some smattering of agriculture was the proper means of meeting the objectives.

Some light on these matters is to be had by a study of the catalogues of certain typical institutions. The president of Cornell University in 1869 said that the purpose of the college of agriculture was "To make master farmers thoroughly based in the sciences relating to agriculture." The University of Wisconsin in its catalogue of 18681869 stated, "It is the design of the University to give in this department (agriculture) a thorough course of instruction directly pertaining to agriculture, which will enable our graduates to conduct the operation of a farm both intelligently and profitably." The Michigan Agricultural College was the first College of Agriculture established in America and as early as 1855 they stated in substance that, "The chief purpose and design of the college shall be to improve and teach the science and practice of agriculture."

In the catalogue of the University of Missouri for 1870 there was but one agricultural course, entitled "Practical Agriculture." In 1872 
the Missouri catalogue published its objective as follows, "The Department of Agriculture is concerned with diffusing agricultural knowledge and cultivating rural tastes."

In 1873 President Anderson of the Kansas State Agricultural College stated the general objectives of his institution as follows, "Whatever else may yet need to be tried there is no use of repeating the experiment of flying a literary kite with an agricultural tail, so often made in various quarters. . . . There is nothing in it for the industrial student whose estate pays for the kite." This statement seemed to suggest something of a change in the real objectives of the Kansas institution. There is evidence that during this early period in the experience of these institutions the administrators were groping. The statement of their objectives cannot be said to have reflected their real accomplishments. There was an evident trend from the beginning in the direction of more technical agriculture in the curricula and with the increase of such courses there was a growing confidence on the part of people interested in agricultural education.

It early became apparent that education in agriculture and mechanic arts prepared men for other activities than farm management. The rapidly growing interest in agricultural education created a nationwide demand for teachers of agriculture, investigators and agricultural specialists in many lines. This new demand upon these institutions is reflected in the statement of purposes of some institutions. For example, in 1890 Cornell University published in its catalogue its objective as follows, "To educate men to become farmers in the broad sense of the word or to become teachers of some one of the branches in the agricultural colleges." In 1901 Iowa State Agricultural College stated its purpose, "To make a foundation for the student upon which he can build a successful career as a farmer or develop into a specialist in the many possible lines that are branches of the farm industry." Michigan Agricultural College in 1897 stated, "To afford instruction along lines that will be of particular value to persons engaged in agricultural pursuits." University of Wisconsin in 1890 published this objective, "To give a thorough and intensive course of scientific instruction in which the leading subjects will be those relating to agriculture."

In accomplishing these objectives there was a decided and notable increase in specialization in the field of agriculture. In spite of public sentiment and in spite of the growing demand for graduates of colleges of agriculture by reason of their specialized training, there is to be noted a tendency to offer a course of instruction that would recognize mental discipline and cultural education along with agriculture and mechanic arts.

From 1887 to the present time the American Association of Land Grant Colleges and Universities has had a profound influence upon the development and general direction of educational effort in these institutions. This Association, founded in 1887, brought together the 
best minds in agricultural education. By conference and discussion there came to be a common agreement as to the essential objectives of these institutions and an essential agreement upon the kind of subject matter and the sequence of courses offered for the purpose of training young men and women for agricultural careers. Some typical utterances of leaders in the Association may be quoted. President W. L. Broun of Alabama at the Association meeting in 1892, in describing the objectives of the colleges of agriculture, made the following comments: "Education that looks to culture alone, while attractive and elevating in its nature and refining in its influence, does not of itself qualify the recipient for active duties of life."

There was clearly observable a definite trend towards specialization in agricultural subject matter by 1910. The Michigan Agricultural College stated at that time that the "Content and purpose of agricultural education in the Michigan Agricultural College was to give each student an overview of the field of agriculture and to permit an opportunity for specialization."

The University of Missouri's College of Agriculture published as its objective in 1910, "The agricultural course trains men and women for successful agriculture. It educates farmers, farm managers, fruit growers, grain growers and stockmen; it prepares men for responsible positions as teachers and investigators in experiment stations and agricultural colleges and in the service of the United States Department of Agriculture."

Dr. Elmer Ellsworth Brown, United States Commissioner of Education before the Association of American Agricultural Colleges and Experiment Stations in 1907, stated, "Our state colleges of agriculture and mechanic arts are to prepare young men and women to read intelligently the literature of scientific agriculture, to form independent judgments on agricultural matters, and to bring their new knowledge into connection with the real work of the farm."

During the period 1912 to 1925 there was a definitely practical trend to the education offered by these colleges of agriculture. The idea that these colleges were also to provide cultural and disciplinary training as envisioned by the literary arts colleges of the day was no longer emphasized. There was no criticism of cultural education. It had its place but there were other goals and other objectives equally important and if the Land Grant Colleges were to accomplish the real purposes of the Morrill Act they must inevitably devote their attention to technical education. As time passed, general uniformity and agreement came to be the rule in the management of these institutions. It is possible to show from the records and study of the catalogues that the real objectives of these institutions involved three basic ideas: (1) to train men to be practical farmers; (2) to train teachers and research workers in the field of agriculture; and (3) to train men and women for social, economic, and general educational services in the field of agriculture. These objectives are specific but sufficiently 
broad to include the broad field of agriculture and rural affairs. The objectives are more or less permanent, but the means may change with the times and with the advancement of knowledge.

\section{EARLY STRUGGLES OF LAND GRANT COLLEGES}

In view of the present progress and development of the Land Grant Colleges of the United States, it is difficult for the present generation to realize the early struggles and difficulties surrounding this development. An unprejudiced view of the early history of these institutions shows clearly that their growth and development has been a continual struggle against substantial odds. They represented, in the beginning, a revolution in college education.

One of the greatest difficulties in the development of the colleges of agriculture in the beginning was to secure successful teachers of agriculture. Most of the teachers in the beginning were either men who had been successful as practical farmers or men of scientific training who were, perhaps, more interested in their science than in its applications. There were too many teachers trying to educate the farmer as they though he ought to be educated. There were too few teachers who were trying to give the kind of education that the farmer really needed. Teachers without farm experience, even though great scientists, proved unsatisfactory. Practical farmers without a knowledge of science were equally unsuccessful.

The teaching of agriculture was a new and untried field. The established, well organized, and systematized subjects were much more easily taught than the new subject of agriculture. In fact, it is doubtful if there was an organized body of agricultural knowledge in 1862 that could be systematically taught. Such science teaching as was attempted had little application to the practice of agriculture. The technique for utilizing science had not yet been developed. The attitude of scientists themselves was often opposed to the idea that the discoverer of truth should interest himself in the use of the knowledge he had discovered. It remained for the Land Grant College to develop successful techniques for the use of knowledge and the ability to put knowledge to work.

It was not until the establishment of Agricultural Experiment Stations by the passage of the Hatch Act in Congress in 1887 that these institutions began to prove to farmers that science could serve agriculture. These institutions also contributed a body of knowledge based on scientific research which eventually made it possible to formulate the subject of agriculture and organize it in teachable form.

For these reasons, and probably others, the early work of the land grant colleges cannot be said to have been successful. They served efficiently neither the purposes of higher education nor did they contribute importantly to the farmers as a class. They were groping for an educational program that would honestly accomplish 
the fundamental objectives that were envisaged by the friends of agricultural education.

It is, I think, a fair observation that in the beginning the separated state college of agriculture and mechanic arts thrived and came to a position of influence at an earlier period than did the colleges of agriculture and mechanic arts associated with the state universities. It is, I think, an equally fair observation to make that, beginning with the twentieth century, the development of the colleges of agriculture and engineering associated with universities has been very rapid and in many respects these divisions of state universities have come to represent a very high type of teaching, research and extension service in the field of agricultural education.

\section{EARLY CRITICISMS OF LAND GRANT COLLEGES}

The establishment of the land grant colleges either as independent institutions or in association with state universities did not settle some of the controversies which agitated the minds of educators and farmers during the efforts to locate these institutions in a favorable environment. For many years after their location, there were very sharp criticisms of the institutions attempting to develop instruction in agriculture and mechanic arts. This did not stop with mere criticism of policies or of the curriculum. In several states where the college was located in connection with a university, the criticisms led to definite efforts to separate the college of agriculture from the university. The source of these efforts was to be found among those who had opposed establishing these colleges as divisions of state universities. It was continually charged that whereas the Morrill law required specifically that the teaching of agriculture and mechanic arts should be the leading object, these universities were not complying with the law. Agriculture was merely another department or division. It was further claimed that too large a proportion of the income was being expended for the salaries of professors of mathematics, science and even Latin. While this use of funds was clearly legal under the first Morrill Act, the objectors insisted that it did not comply with the spirit of the law. Such compliance required that the funds be used chiefly for teaching of agriculture and mechanic arts. It was also claimed that faculty and students in the state universities looked down upon agricultural instruction. Agricultural students were not accepted into full fellowship with other students in the universities. These institutions were criticized because of the small number of students enrolled in the colleges of agriculture and mechanic arts. It was further pointed out that graduates of the colleges did not go back to the farm but became teachers or even entered other professions. There were many citizens of standing and influence, both among university and college educators and among farmers themselves, who held to the sincere belief that you could not teach agriculture in college. 
It was apparent that the colleges of agriculture and mechanic arts were to travel a rugged road. There were no precedents for them to follow. They were the objects of sharp criticism from those who claimed to be friends of agricultural education. Farmers generally were very skeptical of the proposal to teach agriculture in a college. They had little respect for "book farming."

As typical of some of the criticisms, a representative. of the Ohio State. Board of Agriculture in 1872 reported upon a meeting of agriculturists in Washington, D. C., as follows: "Upwards of twenty agricultural colleges were represented there, and not a single one of these colleges except, perhaps, the one at Amherst, Massachusetts made or proposed to make agriculture the leading object of the college." He gained the impression from professors of these colleges that "after the classical and literary part of the college was thoroughly organized, there was no fund with which to do anything more than employ a single professor in the agricultural department." He. further stated that some delegates argued that "it was a proper and legitimate interpretation and construction of the law to make it give the classical and literary course of studies pre-eminence over scientific and agricultural studies."

One of the most commonly expressed criticisms of the early colleges of agriculture was that the teaching of practical agriculture was neglected. In "The Country Gentleman," November 26, 1874, J. Skirving offers the criticism that "the institutions have depended more on teaching the higher branches of science, instead of practical husbandry, having appointed professors well qualified for such instruction but often placing men over the farm department knowing. little of practical farming." Mr. Bryant, Sr., speaking of the University of Illinois in the Transactions of the Illinois State Horticultural Society for 1877 remarks, "I may be mistaken, but it seems to. me the agricultural, horticultural and mechanical industries have not been made the most prominent features of the institution, as it was the design of the founders, and as is contemplated in the law that they should be." In the early history of these institutions there was frequent criticism of the course of study offered to students. The horticulturists were particularly critical of the failure of most. colleges to appoint teachers of horticulture to develop orchards and gardens and in general to give some service to the horticultural in-. dustry. Professor Cyrus Thomas in the Illinois State Horticultural Society report of 1877 , states that the institution should do more for. horticulture; it should have a professor of horticulture; the interests. of horticulture should be pushed to the front. He also insisted that the Horticultural Society and the State Board of Agriculture should have a voice in recommending the teacher to be employed.

Some of these difficulties were in the mind of Honorable J. Stanton Gould writing for the Sixth Annual Report of the Connecticut Board of Agriculture 1872-73, when he said, "The young farmer will 
pass out of their hands thoroughly furnished with all the means and appliances for studying the arts of agriculture, but he will know very little of agriculture itself. These professors will not claim that they can teach them, or that they know it themselves; no man knows it. The true knowledge of agriculture is a thing yet to be acquired." In continuing further, he gives expression to the growing conclusion in the minds of others that before these institutions could accomplish the purposes for which they were established, there must be extensive scientific investigations. "The experiments which must be made, before the foundations of the science of agriculture can be truly laid, are numerous . . . some of them," he says, "may require years . . they must be represented under all possible conditions . . . before results can be used with confidence as the bases of successful agricultural practice." Growing appreciation of this fact, namely the need of investigation and scientific research was further expressed by a Committee of the Iowa State Horticultural Society appointed to report on the agricultural college in 1873, "The results heretofore attained have not fulfilled the just expectations of the friends of agricultural education. Be it resolved that, We recognize in careful and exhaustive experiment the means of largely increasing the fund of available, practical and scientific knowledge."

There were those who even still maintained that the attempt to educate young men for agriculture was futile. Many farmers also questioned the value of science in solving their problems. Mr. James Cook writing for the Michigan State Board of Agriculture for 1877, arguing for the benefits of agricultural education, deplores the shortsightedness of farmers in this respect. He says, "T'is but a few days since one of the most successful farmers in our vicinity said in public that he would like to know what good, what benefit science had been to farmers and what it had accomplished for them that they could not have done without it."

The criticisms so far considered have to do chiefly with the early years of these institutions and it must be said in fairness that they were, in the main, justified. The early years of the land grant colleges were not productive; they satisfied neither the educators in charge of the administration nor the farmers for whom they were established. They themselves represented a great educational experiment. It is probable that if they had not been so firmly established in the first instance by land grants and resulting permanent endowments, many would have fallen by the wayside. There was, in general, substantial agreement as to the intentions of Congress so far as service to agriculture and rural people were concerned but there was a wide diversity of opinion as to how these purposes were to be accomplished. When we look upon the colleges of agriculture of today (1940) with their unrivaled equipment, large and exceptionally well trained faculties, their great research programs and the remarkable services provided through their Agricultural Extension Divisions, we must, I think, be forced to the conclusion that these institutions have 
finally achieved their purposes and have come to be recognized as educational agencies of the first order.

A knowledge of the real development of these institutions certainly would not support the idea, formerly held in some quarters, that agricultural education has been neglected in favor of engineering. They do not at the present, whatever may have been the case in the past, maintain low standards either in teaching or research. Having in view the thousands of young men and women now clamoring for admission to the colleges of agriculture throughout the United States, it cannot be said that these institutions have as a primary object the securing of more students: the students are coming.

These institutions plead guilty to convincing the appropriating bodies both federal and state that the type of education which they represent not only has rendered great service to agriculture and rural people but has so served the public welfare that great business corporations, railroads, bankers, chambers of commerce, and manufacturers have given their generous support to these institutions.

Their educational programs are based upon the needs of modern civilization. They have demonstrated that there is more than one education, that education may serve the common man, that brilliant intellectual attainment may be usefully applied to the solution of life's problems.

\section{EARLY EFFORTS TO TEACH AGRICULTURE}

The growing interest in education for agriculture could not be entirely ignored by established colleges and universities in the early years of the nineteenth century. After all, the United States was predominately agricultural. Its civilization was a rural civilization. Its interests were in land development and land use. The federal government controlled a vast public domain, as yet undeveloped but of great potential value.

There was little exact information available in this country which could aid the cultivator of the soil. He was continually confronted with problems which were not only beyond his power of solution but no organized and systematic effort was being made to help him. Scientific research was in its infancy but beginning to prove its competency to solve many of the troublesome problems of manufacturing and industry.

It is not strange therefore that many institutions bound to the classical tradition began hesitantly to consider the introduction of science courses in the curriculum. These grew in importance and gradually proved their value, not only to education but to the immediate benefit of everyday life. This development of science in the United States followed the general interest in Europe, caused by the chemical researches of Lavoisier and Boussingault in France, Sir Humphry Davy in England, and Liebig in Germany. All of these 
chemists made important contributions to agricultural chemistry. The works of Liebig in Germany, "Chemistry in its Application to Agriculture" and "Animal Chemistry", became guides to similar studies in this country. Many of the early teachers of agricultural chemistry in the United States were students of Liebig.

So important were the relations of chemistry to agriculture in the early years of agricultural education that it was not uncommon to publish the subject agriculture in the curriculum and after it the word chemistry in parenthesis to indicate the paramount importance of this earliest of the sciences to agriculture.

The effort to satisfy the demand for some specific instruction in agricultural subjects led some established colleges and universities to add this subject to their curricula before the passage of the Morrill Act of 1862. The first curriculum of the University of Pennsylvania, published in 1754, included the chemistry of agriculture. The Gardiner Lyceum, an agricultural school at Gardiner, Maine, was opened for students in 1823. The second principal of this school was John H. Lathrop, later to become president of the University of Missouri. The first catalogue (1824) of Washington (now Trinity) College at Hartford, Connecticut announced its intention to establish an agricultural unit and a botanic garden. Amherst College announced a "lecturer on agricultural chemistry and mineralogy" in 1843. Jefferson had included agriculture in his plans for the University of Virginia (1825) but owing to lack of funds for the proposed professorship, the chair of agriculture was not filled.

In $1846 \mathrm{John}$ Pitkin Norton was appointed professor of agricultural chemistry and vegetable and animal physiology in the Yale Scientific School. The Maryland Agricultural College was opened for students in 1859. The first professor of agriculture and chemistry and its application to the arts, geology and mineralogy was George C. Shaffer. In 1858 Professor Geo. C. Swallow later to be dean of the Missouri College of Agriculture was permitted by the Board of Curators to offer a course in agricultural technology in the University of Missouri.

These first feeble efforts to teach an obviously important and needed subject were in the main unsuccessful and were in most cases abandoned. The nation was not yet ready for the kind of agriculture taught by these institutions. Indeed it is doubtful if there existed a body of knowledge which could be taught at that time. Another reason for the general failure of these efforts was that the proponents of agricultural teaching seemed unwilling that agriculture should be made the tail of the educational kite. They insisted upon a more prominent place in the educational system. They demanded an agricultural college, the leading object of which should be the teaching of agriculture and later the conduct of agricultural experiments.

Typical of the early efforts to teach agriculture in established colleges and universities was the attempt made by the University of 
Michigan in 1853 to establish a department of agriculture. It seems, from the records, that there were two influences at work which led this university to undertake the teaching of agriculture on the university level nine years before the passage of the Morrill Act of 1862 . The law, passed and approved March 18, 1837, establishing the University of Michigan, provided for three divisions: “(1) Literature, Sciences and Arts, including instructions in Practical Farming and Agriculture; (2) Law; and (3) Medicine." The legal charter, of the University therefore, included agriculture as one of the subjects to be taught. The second and impelling, immediate influence operating in 1853 was a general movement of members of the Michigan State Agricultural Society and other friends of agriculture to secure a grant of 22 sections of the so-called Salt Springs lands for the maintenance of an Agricultural School. The legislature was empowered by the new constitution of that time to establish this grant for the maintenance of an Agricultural School and it was provided further that "they (the legislature) may make the same a branch of the University for instruction in agriculture and natural sciences connected therewith, and place the same under the supervision of the regents of the University."

It was in anticipation of this grant that the University hastened to organize an Agricultural School as a part of the scientific course "recently adopted by the faculty and regents." The first effort by the University in this direction was to offer a short course of instruction commencing April 1st and ending June 30th, 1852. The subjects to be offered were indicated in a letter from President Henry P. Tappan to Secretary James C. Holmes of Michigan State Agricultural Society, dated February 1, 1852, the subject were: (1) daily lectures on chemistry, (2) geology and mineralogy, (3) animal and vegetable anatomy and physiology, (4) organic chemistry and the theory and practice of agriculture, the origin and nature of soils, the different varieties of manure, tillage, tools, etc., etc.

An article written by C. Fox in "The Farmer's Companion and Horticultural Gazette" of Detroit, Michigan, April 1st, 1853 under the title "To the Young Men of Michigan" the following statements were made: "Hitherto, the University has only held out inducements to such young men as wished to follow one of the so called 'learned professions'-medicine, law, and divinity. A change, a most important change, is now made. The larger proportion of the citizens of Michigan are farmers. . . . An 'agricultural course' is now instituted, for . . . teaching such persons as intend to follow this business. This has been done at Yale and Harvard Colleges in the East, and proved to be most popular and beneficial."

Mr. Fox in an argument states that agriculture is one of the most socially important, complex and "one which draws into its service the greater portion of the other arts and sciences. . . ." He continues "It is a novelty, but none the worse for that. Before you are 
middle aged, such educated farmers will, we trust, be the majority of their class."

Later Mr. Fox was appointed to the position of professor of theoretical and practical agriculture, but the plans of the University for a well organized department of agriculture were practically abandoned upon the death of Professor Fox, a short time after his appointment.

This effort of the University was not whole-heartedly endorsed by the friends of agricultural education. In an article in "The Watchtower", Adrian, Michigan, January 18, 1853, a Mr. Pilcher criticized the subject matter offered as being "impracticable and almost, if not worse than a useless thing. . . . What we need and must have, is a school in which agriculture will hold the first place and not be put at the tag end of every thing, as in this case."

$\mathrm{He}$ continues, "I propose the establishment of an agricultural college, full grown and independent." He continues further, "a college is needed in another location, surrounded with other circumstances to meet the wants of our agriculturalists."

This discussion as to the relative position of agricultural teaching in an institution, and the insistence upon having a real agricultural college and not a mere appendage to an established institution, is interesting and typical of similar controversies at a later time, after the colleges of agriculture and mechanic arts had been authorized by Congress.

The logic was all on the side of joining the teaching of agriculture to the University. The sentiment of farmers, however, was against it and in favor of a separate school where agriculture would occupy a major and not a minor position. Sentiment won and the Michigan Legislature in 1855 provided for the establishment of the "Agricultural College of the State of Michigan" and directed that "the chief purpose and design shall be to improve and teach the science and practice of agriculture".

Thus was established the first College of Agriculture in the United States. It was therefore entirely natural and, in this case, logical to designate the agricultural college already established by the Legislature as the appropriate institution to receive the 22 sections of Salt Spring Lands and later the benefits of the Morrill Act of 1862.

\section{SCOPE OF AGRICULTURAL TRAINING}

The colleges of agriculture have never lost sight of their major purpose which was and is the education of young men and women in the broad field of agriculture. While in the popular mind they are primarily concerned with the training of students in the principles and practices of farm enterprise, the actual result of their training has been to prepare them for a great variety of successful enterprises in which a knowledge of agriculture is important. Broadly speaking, the training now offered in the colleges of agriculture represents the best thought and advanced practice in the conservation 
and development of our natural resources, in particular, all those natural resources which have to do with the utilization of land and the products of the soil.

It is highly important that these institutions prepare large numbers of their graduates who will become practical farmers, either on their own farms or as managers of estates. But it is even more important that the young men trained in the college of agriculture who, for any reason, may become teachers of agriculture, agricultural extension agents, or researchers in agriculture shall have a thorough, sound training in the sciences upon which modern agriculture is builded.

From the standpoint of the public welfare, the agricultural teacher either in a college, a high school, or as a county agricultural agent will, under present conditions, have a much more far reaching influence upon agriculture in general than will a student and a graduate who is limited to his own landed estate. However, too small a proportion of the students graduating from colleges of agriculture have become actual farmers. This is not to say that too large a number have become teachers and extension agents, since in the very rapid development of the educational agencies for agriculture in recent years the colleges of agriculture have found it necessary to utilize a very large percentage of their graduates in the field of agricultural education. Great expansion has taken place in both vocational agriculture and in extension work and these activities have required agricultural training.

In very recent years there have been added to these established agencies agricultural activities of the Federal Government, such as the Soil Conservation Service, the Farm Security Administration, the Agricultural Adjustment Administration, the Farm Credit Administration, the Regional Laboratories for Agricultural Research, and others. All of these have required men trained in the colleges of agriculture and graduates of promise have been rapidly absorbed.

The time is rapidly approaching, if not already here, with the very rapid increase in the number of students registering in these colleges, when a larger and larger number will find their opportunity in developing the agricultural resources of our country on the land. It will be a great day for the agriculture of this country when a large number of farmers have been trained in colleges of agriculture in the most modern methods of soil conservation, of prevention of plant and animal diseases, and the most successful methods of crop and livestock production.

Under conditions as they exist at the present time (1940), there is more need of exact knowledge based upon careful research than in any previous period of our agricultural history. Knowledge alone will not suffice. It is still true that industry, executive ability, and good judgment are essential qualifications for the successful farmer, but if the knowledge developed by the agricultural experiment sta- 
tions is added to these qualifications, the probability of success on the farm will greatly increase.

After all, the most important and most lasting of all our national resources is the soil. The continued prosperity of the nation depends upon the intelligent conservation and development of this natural resource. The soil may be exhausted but it cannot be destroyed. It can be moved through erosion but may be deposited in a new location and in the course of time may again become productive. But this process is enormously costly in time, and in the economic status of present-day farmers, communities, states and ever the nation itself. We cannot safely permit, as a nation, the exhaustion of our soils either from unintelligent cropping or from erosion. The most effective and lasting measure for escaping the collapse of agriculture in this country is education. The colleges of agriculture are the only institutions fully equipped first to establish the facts, second to develop the techniques, and third to extend a knowledge of these techniques to actual owners and cultivators of the soil.

The colleges of agriculture were established in the beginning in response to a great need-the need to conserve our national soil resources. The need is greater today than in 1862, when President Lincoln signed the Morrill Act, creating these colleges. The industrial revolution has in some manner resulted in the impoverishment of agriculture. Economic conditions for seventy-five years have tended to build great cities, great public utilities and great public improvements. The enormous wealth created on the farms of America has not remained in the open country. The farmers' wealth in soil fertility has continuously diminished and this is so despite the fact that important discoveries made by the experiment stations have resulted in significant decreases in the cost of production. It would seem that the farmer, impelled by the inexorable pressure of economic conditions, has utilized this new knowledge to save himself from economic collapse, but has been unable to practice adequate conservation methods to preserve his heritage of soil fertility. This is, of course, a very vital matter. Vast efforts are now being made to aid the farmer in recapturing his soil fertility and preventing further loss. We may well raise this question, "If all these soil conservation methods are successful can the farmer hold his gains or will he again be forced to exhaust his soils to save his home?"

The American consumer has, to some extent, been a party to the depletion of our soil resources. From the very beginning, low prices for agricultural commodities have been at the expense of gradually diminishing soil fertility. The American public has been educated to low prices for agricultural products. Low prices for these products have influenced the farmer to cultivate more and more land in order to secure an adequate standard of living. The result has been cheap food and fiber for the American consumer, but at the cost of continually declining fertility and a comparatively low standard of 
living for the farmer. It is very difficult under present conditions to insure a price for farm products that will provide a reasonable though simple standard of living for the farmer, and make it possible for him to practice such methods of conservation as shall not only save the fertility in his soil, but to improve his soil in such manner as now seems essential for a profitable and permanent agriculture. 


\section{THE EVOLUTION OF THE AGRICULTURAL CURRICULUM}

It was one thing to accept land grants for the establishment of colleges of agriculture and mechanic arts and quite another to organize a teaching program that would successfully accomplish the purpose of the founders. It was one thing to announce in the advance publications of the early institutions that the college was now ready to receive students and quite another to provide the instruction necessary to accomplish the real objects contemplated in the law and in the minds of the friends of agricultural education. In this connection it must again be stated that at first very little attention was given to the problem of providing instruction in mechanic arts. There was great interest in agricultural education. In most states the agricultural curriculum was the only course offered in the beginning. In fact many institutions were founded under the name "Agricultural College". Thus we find independent colleges organized under the name, Agricultural College, in Michigan, Maryland, Kansas and Massachusetts, although in the latter state the funds were divided, one portion going to Massachusetts Institute of Technology for instruction in mechanic arts. The greater number of the independent colleges were organized under the name "College of Agriculture and Mechanic Arts". At a later period, with the great development in manufacturing, railroad building, and other industrial enterprises, instruction in mechanic arts under the generally accepted title of Engineering came to be a very important function of all land grant colleges. The engineering departments were developed more largely from state appropriations while Congress and the public still generally continued to think of these institutions as colleges of agriculture. This fact seems to be proven by the later large federal appropriations for agricultural experiment stations and for agricultural extension services.

In the early years there was little specialization. There was great difficulty in finding satisfactory teachers. The colleges had provided practically no equipment other than land. No one at that time knew how to utilize land as a laboratory for instructional purposes. Those who believed that a good course in science would be sufficient preparation for life on the farm, organized science courses with little emphasis on their applications to be varied and complex problems of agriculture. Those who emphasized the actual management of farms often made the mistake of appointing a successful farmer without teaching experience and limited, of course, to his own farm experience.

The fallacy of assuming that a preparation in pure science is adequate for a training in agricultural enterprise is a point made by Dean Alfred Vivian in an address before the Association of Land Grant Colleges in 1923. He says, "One of the greatest fallacies cherished by many of the teachers of the so-called pure sciences is that any one who is grounded in the laws of science considers himself 
well accomplished in applications in his chosen vocation. Many men highly trained in pure science are utterly lacking in the gift of making the practical applications of the laws of that science to the affairs of daily life."

There were at least three ideas prevailing as to the general organization of the curriculum. In the early days in the college of agriculture, there were many who still clung to the idea that, after all, a liberal education, embracing the same general education policies and methods which had so long prevailed were the best methods and philosophies for the new colleges of agriculture. There were others who favored a more technical course but believed that sound training in the known sciences, particularly chemistry, constituted the proper basis for a training in agriculture. A third group had little patience with either those who believed in a general culture course or a purely science course, insisting that the college of agriculture was established to teach agriculture, that agriculture was an applied science and no teaching of chemistry or of botany or of physics could, by any stretch of the imagination be classified as agricultural teaching. The latter group included in their thinking a certain amount of fundamental science but insisted that instruction must not stop there but must include courses in science applied to agriculture. Therefore, in the early records of these institutions are to be found curricula embracing each of these ideas. The real difficulty in attempting to teach agriculture as an applied science was that there was no sufficient accumulation of knowledge of science as applied to agriculture. The great development of agricultural research had not yet provided the necessary basis for a solution of the farmers' problems.

In the beginning, all subject matter was organized under the one comprehensive title of agriculture. There were no departments of animal husbandry, dairy husbandry, soils, and horticulture. Usually one professor of agriculture was required to know and to teach useful knowledge of all these different phases or types of farming. Special interests soon began to clamor for teachers in their fields of enterprise. It did not seem to them reasonable that a teacher expert in horticulture and plant lore should be trying to teach farmers the principles of animal nutrition. It soon became obvious to all concerned that the road to success in agricultural teaching lay in the direction of more specialization. There was ample justification for the demands of the dairy industry that what was needed was a skilled teacher in dairy production and another in dairy manufacturing.

Among the very first to demand a full-time teacher for their subject were the horticulturists. In a number of states, therefore, we find fruit growers demanding that the colleges provide professors of horticulture. At first this subject was often associated with a department of botany, but this arrangement was only temporary and not entirely satisfactory to the friends of horticultural teaching, so we find, in a number of institutions, that a professor of horticulture was 
co-equal with the professor of agriculture in point of salary and position. Thus we find horticulture organized as a separate department at Michigan (1867) New York (1874), Ohio (1876), and Iowa (1876). The friends of horticulture did not stop, however, with a full time professor of this subject but very soon demanded that the new subject of entomology be recognized as a department and a full time professor of entomology be appointed.

Later, dairy manufacturing assumed a large importance. In some institutions a professor of dairying, giving his chief attention to manufacturing dairy products, was added to the staff. Successively other specialized departments were carved out of the department of agriculture. Animal husbandry, dairy husbandry, soils, field crops, agricultural engineering, poultry husbandry, horticulture, entomology and farm management became regular departments in every well organized college of agriculture. At a later time the social sciences were added. Departments of agricultural economics and rural sociology were given a prominent position in the teaching and research departments of these institutions.

The beginning of specialization in agriculture was the beginning of success in the colleges of agriculture. It was greatly accelerated by the establishment of the agricultural experiment stations in 1887 . Specialization in the field of higher education assuredly has certain disadvantages but its justification is to be found in the limitations of the human mind. Alexander Pope in his essay on "Criticism" wrote, "One science only will one genius fit: So vast is art, so narrow human wit."

The first colleges of agriculture were of two classes. The first offered a curriculum largely cultural with a minimum of so called agriculture. The second gave chief attention to agriculture, so called, and science. There were, of course, all kinds of variations between these two extremes. The agriculture offered was very meager both in quantity and quality. Science as a subject of higher learning was still in its infancy. Chemistry and physics were the first sciences to be included.

The first professors of agriculture, particularly in New England, were chemists. Professor Norton of Yale College, a chemist, was appointed professor of agriculture in 1846. Later his title was changed to professor of agricultural chemistry. He was the author of a book with the title "Elements of Scientific Agriculture". Professor S. W. Johnson, a chemist, also of Yale was the author of two important volumes "How Crops Grow" (1868) and "How Crops Feed" (1870). He was appointed professor of theoretical and agricultural chemistry at Yale in 1875 . He was later director of the Con-necticut Agricultural Experiment Station (1877). Dr. R. C. Kedzie was the professor of chemistry in the Michigan Agricultural College (1863). His chief contributions however were in agricultural chemistry. 
It seems to be well established that what might be designated as practical agriculture began with chemistry, and instruction was chiefly confined to the relations of chemistry to agriculture. It very soon became evident that chemistry was not the only science basic to agriculture. Professor Johnson, himself a chemist, warned in 1856 that "Agricultural chemistry is only a part, . . . vegetable and animal physiology figure quite extensively in . . agricultural science."

The rapid development of specialization in the colleges of agriculture from about 1900 has had an important influence on the curriculum. Whereas the teachers of agriculture were confronted with the problem of finding adequate content for agricultural subjects in the period from 1862 to 1895 and later, the situation in 1940 is to find time and a place in the four-year curriculum to teach all the accumulated worth while knowledge desirable or necessary. There are, of course, many who deplore the general trend in education toward greater and greater specialization. There are many critics of the colleges of agriculture who look upon this increase in the time devoted to strictly agricultural subjects as an unfortunate tendency. These critics would have these institutions devoting much more attention to the basic sciences and the humanities. They offer the same objection to the curriculum of the college of agriculture that they offer to other institutions organized for technical training. Many are concerned over the fact that these technical institutions deal too exclusively in the particular subject matter pertaining to their professions and fail to acquire a knowledge of human relations.

Too often students in technical institutions have received no insight, have no knowledge or appreciation of philosophy, psychology, logic, and humanistic studies. This is a just criticism. But at the same time the demand upon these graduates upon leaving their alma mater is for the most complete and accurate technical information available. Their success in their chosen field depends upon their exact knowledge of the special field in which they are engaged.

The dangers of too much specialization seems to have been a favorite subject of debate among the wise ones in the earlier years of the land grant college. The educational philosophy of technical education was a direct challenge to the proponents of an education for liberal culture. The urgent necessity for more and more technical knowledge caused most institutions to increase rapidly the degree of specialization required for technical degrees. It was not only the advocates of a liberal culture who deplored this tendency but in the land grant colleges themselves, we find a reflection of this point of view. In 1897 a standing committee of the Association of the Land Grant Colleges and Universities in urging a more general and unified course in agriculture made this statement regarding the dangers of specialization: "It will do much to counteract the pernicious influence of a narrow specialism which has in recent years been fos- 
tered by a false eclecticism." This statement was not made in connection with an argument for a more liberal culture but rather for a more general course in agriculture itself.

Despite the evident distress of the intellectuals of the old school, greater and greater specialization continued in all technical schools. It is interesting to note in this connection that the widespread popularity of agricultural colleges is co-extensive with the development of specialization. When the colleges of agriculture were able to demonstrate to the orchardist that the institution could supply all the worth while information needed in the development of an orchard and when the same institution could provide a complete education in dairy husbandry, based on the researches of the experiment stations, the colleges of agriculture began to be recognized and generally approved by their constituents.

From the very beginning, the faculties of agriculture have wrestled with the problem of the proper balance between science, technical agriculture, and subjects taught in the liberal arts college. In 1896 Professor Thomas F. Hunt of Ohio speaking before the Tenth Annual Convention of the Association of Agricultural Colleges and Experiment Stations held that the curriculum should be one-third technical work of applied science, one-third science, and one-third language, history, and philosophical studies. In the same year and at the same convention Professor S. W. Johnson presented the attitude of those who still clung to the traditional idea of education. He said that in agricultural and industrial education much good use may easily be made of both Latin and Greek. His reasons were that these subjects were universally taught in preparatory schools because they afford mental discipline, and a knowledge of Latin and Greek facilitates the use of the English language, mastery of the nomenclature of science, and a help in acquiring the knowledge of the modern languages.

Behold how great a change has taken place in the curriculum of the colleges of agriculture. How little importance today do we give to the classics as foundation of an educational curriculum. It is even possible to secure the bachelor of arts degree from a good university today without having had Latin or Greek.

At this same conference (1896) Dean H. J. Waters of Missouri, discussing the results of a study of the curricula of a large number of colleges, remarked that these institutions were still experimenting with curricula; there seemed to be no uniformity. Contrasting the extremes, he pointed out that four-year graduates in one college were required to have 49.9 per cent general culture courses, 24.6 per cent non-technical scientific, and 25.4 per cent technical: the other extreme required of students 8.1 per cent general culture, 39.3 per cent non-technical scientific, and 52.6 per cent technical. He continued, "A majority of the colleges of the country have made their course a happy medium between these extremes approximately as 
follows: general culture, 24; non-technical scientific, 46; and technical, 30."

In 1921 there was presented to the Annual Convention of the Association of Land Grant Colleges a paper by Carl R. Woodward, at that time based on the survey of the forty-eight colleges of agriculture. The requirements were stated as follows: academic, 22 per cent; science, 24.5 per cent; agriculture, 38.9 per cent; free elective, 14.6 per cent. He reports that the greatest specialization is to be found in the larger colleges of agriculture in the Middle West.

From the beginning, builders of curricula have generally agreed that the first two years of the agricultural curriculum should be made up principally of basic science, that the mastery of these subjects was necessary in order to understand the later courses in practical agriculture. It has been claimed that this is in line with the best modern educational theory. It is, however, to be noted that this opinion is by no means unanimous. Certain institutions have argued that, after all, students come to the college of agriculture to study agriculture, and to delay all of the practical courses in agriculture to the junior year is illogical: the student loses his interest in his primary field of intellectual enterprise.

To meet this difficulty, many institutions have compromised by offering one or two technical subjects in the freshman and sophomore years. This has been followed with good results, but some argue, why limit these courses to one or two. If one or two can be given successfully, why can not a majority of the technical courses be offered in the freshman year? A few institutions have answered this question by offering introductory courses in most of the so called technical subjects; animal husbandry, dairy husbandry, soils, horticulture, etc., in the freshman year. The science courses follow in the sophomore and junior years. It is, perhaps, too early for a final estimate of this policy but so far it seems to have been satisfactory and has resulted in real improvement. After all, we must remember that the technical courses in agriculture of the present day are themselves science courses and that in requiring these in the freshman year, we are not denying science instruction but only the kind of science instruction that has generally been accepted as the only pure science.

In general it is safe to conclude that in the evolution of requirements, during the twenty-five years preceding 1940, there has been developed substantial uniformity. At the present time any student graduating from the college of agriculture will have essentially the same subject matter based upon the same scientific research and, within reasonable limitations, conforming to the best thought as to the proper training of a student who is to receive the degree of bachelor of science in agriculture. This does not mean, of course, that all teachers and all institutions are equally efficient or wise in the selection of subject matter nor in the methods of presentation. It is 
still true, as always, that some institutions and some teachers provide a more adequate training.

The evolution of the agricultural curriculum has been indicated in an excellent paper by Mr. E. H. Shinn on the subject "Trends in Agricultural College Curricula", presented before the Annual Convention of the Association of Land Grant Colleges and Universities, November, 1934. In this paper he has the following comment: "Curricular trends in agricultural colleges during the first twenty or thirty years showed that these colleges maintained much of the traditional subject matter and continued to hold strongly to the requirements in foreign languages, mathematics, and physics." $\mathrm{He}$ calls attention to the report of the survey carried out by the Office of Education in 1930, showing that the major changes made since 1880 had been general elimination of foreign languages as a requirement, the reduction of the requirement in mathematics, physics, and chemistry and increases in economics and electives.

Since one of the most important problems confronting agricultural faculties has always been the proper balance between science, humanities, and technical agriculture, the following table taken from Shinn's paper is worthy of inclusion.

DISTRIBUtion IN AgRICULTURAL CURRICULA

\begin{tabular}{lcccc}
\hline Institution & $\begin{array}{c}\text { Humanities } \\
1934-35\end{array}$ & $\begin{array}{c}\text { Science and } \\
\text { mathematics } \\
1934-35\end{array}$ & $\begin{array}{c}\text { Technical } \\
\text { agriculture } \\
1934-35\end{array}$ & $\begin{array}{c}\text { Technical } \\
\text { agriculture } \\
1917-18^{*}\end{array}$ \\
\hline Afizona & 16.5 & 45.6 & 31.6 & 29.7 \\
Illinois & 17.8 & 33.2 & 44.2 & 42.6 \\
Indiana & 18.5 & 38.8 & 38.8 & 41.0 \\
Kansas & 28.2 & 35.0 & 33.0 & 48.1 \\
Iouisiana & 32.2 & 5.8 & 42.8 & 35.0 \\
Maine & 19.2 & 36.5 & 35.5 & 37.0 \\
Maryland & 19.2 & 33.0 & 42.0 & 30.5 \\
Michigan & 22.5 & 39.0 & 28.5 & 37.1 \\
New Jersey & 23.2 & 38.8 & 43.2 & 37.0 \\
Ohio & 21.4 & 31.1 & 40.5 & 39.0 \\
Pennsylvania & 22.0 & 30.5 & 48.2 & 49.0 \\
Tennessee & 18.2 & 22.5 & 28.5 & 34.5 \\
Texas & 13.8 & 50.0 & 49.9 & 26.0 \\
Virginia & 12.8 & 24.0 & & \\
Washington & 20.7 & & & \\
\hline
\end{tabular}

*Bureau of Education Bulletin No. 29, by C. D. Jarvis. 1918.

It is to be observed from this table that, eliminating a few extreme examples, there is substantial uniformity in the distribution of time between the humanities, science and mathematics, and technical agriculture. The table also indicates a few significant changes in the percentage in technical agriculture required. In the main, however, the amount of technical agriculture has remained substantially the same during the period of 1917 to 1934.

All technical education including that of colleges of agriculture has been the subject of criticism, as already noted, for too narrow a specialization. To a certain extent this criticism is well founded. We have developed a remarkable knowledge of and control over the materials and forces of nature but have neglected to provide a satis- 
factory knowledge and appreciation of the real meanings and social implications of these new forces. Human relations in general and the relations of humans to these new forces constitute a field of knowledge which must be better developed. Albert Einstein writing in Sigma Xi Quarterly of September, 1938, asks the question and himself gives the answer, "Why does this magnificent applied science which saves work and makes life easier bring us so little happiness?" The simple answer runs, "Because we have not yet learned to make a sensible use of it."

How far and in what way can the curriculum be changed to provide a deeper understanding of all these new forces to human welfare? Is the teacher in college competent to guide this great army of technicians in the campaign to develop a higher social efficiency in our American Democracy? Is a four-year college course long enough to teach the technical knowledge which is essential and also give adequate attention to the philosophy of human welfare? It is to be remembered that graduates of the colleges of agriculture are occupying important positions of leadership in rural affairs. The county extension agents in agriculture and home economics are in places of recognized influence. The acceptance of their leadership by rural people is the result chiefly of their technical knowledge. But their functions extend or should extend beyond and above mere technical information. Perhaps no one is yet wise enough to determine what effect this new knowledge and new vision may have on rural life itself. The meaning of life and particularly rural life is certainly a fruitful field for intellectual inquiry. The colleges of agriculture must do more in this field. Not only extension workers are occupying important positions of leadership, but teachers of vocational agriculture, employees of the United States Department of Agriculture, Federal land bank employees, and those in a score of other activities requiring the kind of technical knowledge available in the college of agriculture-all these would be better leaders if fired with a social vision based on a sound course of teaching such as only these institutions seem able to provide.

It does not seem probable that the conventional courses in public administration now offered in many institutions will satisfy this need. Such courses are themselves technical. There is, however, need for some instruction in colleges of agriculture in the field of public administration. A very large number of the graduates of colleges of agriculture are today (1940) filling public positions which involve administrative functions. They are not generally receiving undergraduate instruction in this field. It is not more technical courses that are needed in most instances, but a philosophical adjustment of all this knowledge to a good life on the farm.

The course of study leading to the degree of bachelor of science in agriculture is highly scientific. The establishment of the agricultural experiment station as a division of the college of agriculture was a very definite recognition of the fact that the teaching of agri- 
culture was based upon science, that one of the most important factors in agricultural production was a knowledge of natural laws, that the farmer, perhaps more than any other industrial group, was dependent upon the laws of nature and was subject to them. His success as a cultivator of the soil depended upon his ability to control the forces of nature and direct them toward his own ends.

The location of these experiment stations at the college of agriculture was a further recognition of the fact that successful agricultural teaching must be based upon accurate scientific research. The wisdom of this relation has long since been clearly established. Agriculture, as taught in these institutions, is a vital subject; it is vitalized by continued contributions made by researchers. Perhaps in no other university discipline, has college teaching been founded so completely upon accurate painstaking research. All agricultural teaching is scientific teaching. It is no less science because it is purposeful and objective. It is science applied. It is the knowledge resulting from scientific research which is made workable. It is no less fundamental than so-called pure science research because the initial purpose was to solve a definite problem. Some of the most fundamental researches in the higher reaches of science today are being undertaken in the agricultural experiment stations.

The union of the agricultural experiment station and the college teaching function of the land grant institutions have saved the college from dry rot. Agricultural teaching is not satisfied with the accumulated knowledge of thousands of years of agricultural history although such knowledge is useful and fully utilized. Agricultural institutions teach not only the knowledge of all the best methods of agriculture of all the ages, the best farm practices developed by farmers through generations of effort, but also all the knowledge of all the sciences related to agriculture. These knowledges have been organized, systematized and placed in teachable form and are available to the students in these institutions.

The faculties of the colleges of agriculture are in substantial agreement as to the content of the four-year curriculum leading to the degree of B. S. in Agriculture. They are not in complete agreement upon the sequence of subjects. This variation in the arrangement of the curriculum is undoubtedly influenced by the great variety of professional opportunities available to students who have graduated from these institutions. The curriculum which has been devised for the training of students for agricultural enterprise is, in general, the best training for the various opportunities open to graduates. But the faculties of institutions vary somewhat in respect to the importance given to training for farming, for teaching, for research, for extension, for enterprise in the business world or the numerous related activities. 



\section{PART II.-DEVELOPMENT OF THE LAND GRANT GOLLEGES}

\section{REQUIREMENTS FOR ADMISSION}

The colleges of agriculture established in 1862 were definitely assigned the task of providing a college education for rural people. It was early recognized that a very small percentage of the available student material in the rural communities was adequately prepared for college work. These institutions then were faced with a difficult problem. If they required conventional entrance requirements, they would deny a college education to the very people they were organized to serve. If they admitted inadequately prepared students from the rural communities, they could not hope to give a college education leading to a baccalaurate degree comparable with the grade of college education offered by the best colleges and universities. The result was a compromise. These institutions admitted students to the college of agriculture who had less than a four-year high school preparation.

It must be remembered that from 1862 to 1899 there were very few, perhaps no high schools in the rural communities. The colleges of agriculture were not the only colleges that compromised with this problem. A critical study by E. C. Broone, graduate student in Columbia University, New York, 1902, clearly indicates that there was no standardized plan of entrance for American colleges about the middle of the nineteenth century. Dr. Broone says, "There existed in many cases wide diversity between the regulations on paper and the actual practices in the institutions". There was also the fact, so far as preparation for a course in the college of agriculture is concerned, that most academies based their college preparatory work largely on proficiency in Latin and Greek. The administrators of colleges of agriculture were doubtful about this kind of preparation for a technical education based on science.

This whole problem of admission requirements to universities was of such general interest that in 1892, the National Education Association appointed the famous Committee of Ten. This committee reported in 1899. The results of this report did much to standardize and coordinate the entrance requirements for all colleges. In general, the records show that the entrance requirements of leading colleges of agriculture from 1862 to 1893 gradually advanced, beginning with the seventh or eighth grade preparation. There was a general increase in entrance requirements from 1893 to 1913. Since 1913 practically every one of the leading colleges of agriculture in the United States have required 15 units or a full high school preparation for admission. In other words, the requirements for admission 
to a first rate college of agriculture are now the same as for the admission to the college of arts and science and other divisions.

The specific subjects required vary somewhat. Colleges of agriculture generally accept for admission more vocational subjects, such as vocational agriculture and vocational home economics. It is noteworthy, however, that liberal arts colleges feel that vocational subjects are not the best preparation for liberal arts education. It is, nevertheless, true that because of the great increase in the amount of vocational work now given in high school that liberal arts colleges have been led to accept a substantial amount of vocational work for admission. A number of studies have been made of the college experience of students receiving the traditional high school preparation for college and of those students who have offered a substantial amount of vocational work. There is, as yet, no clear evidence that students of equal ability, but offering a proportion of vocational subjects for college entrance, have any greater difficulty in college than students who have pursued the traditional high school curriculum. Agricultural teaching has come to be so definitely based on science that at least one leading university now accepts one unit in vocational agriculture for its entrance requirement of one unit in science.

\section{MANUAL LABOR REQUIREMENT}

There is abundant evidence in the records of the establishment of the colleges of agriculture to indicate that the administrators responsible for the conduct of these institutions were generally agreed that theoretical training alone would not completely accomplish the purposes for which these institutions were founded. There was, therefore, rather general agreement as to the desirability of requiring manual labor in the curriculum. The arguments in favor of this seemed logical although there was not always clear thinking on the question as to whether this labor should be educational or mere manual labor without emphasis on its educational value. Some of the arguments seemed to indicate that the discipline involved in the labor requirement was sufficient reason for its requirement. The principal arguments as found in the writings of teachers of agriculture, educational authorities, and farmers may be stated as follows:

Agriculture was, after all, an art and required a deal of manual labor for its success. Education in the absence of labor on the farm might lead to a distaste for agricultural pursuits. Educated people generally were inclined to look down on those who worked with their hands. By requiring actual labor on the farms these colleges might dignify labor and thus remove the stigma imposed upon labor. It was argued that four years of study in the absence of manual labor would destroy habits of industry. Certain skills are essential to the vocation of farming and these should be taught. Farm labor had an educational value and would be particularly useful in teaching students habits of observation. After all, the farm and garden were the laboratories 
for agricultural instruction and as necessary as laboratories for chemistry or physics. Many friends of agricultural education emphasized the importance of labor as a health measure, and finally, students would be paid for their labor and thus could pay a part of their expenses while attending these institutions.

These arguments, all favorable to requiring actual labor on the farms and gardens in an agricultural curriculum, seemed logical. So much were the legislatures of the several states impressed by these arguments that several actually provided in the basic laws a requirement for manual labor. For example, the legislature of the State of Michigan, in a law approved February 12, 1855, provided that manual labor be required of all students in the Michigan Agricultural College. As a result of this requirement, this institution required manual labor of its students during a period of nearly forty years. Since it was the first agricultural college to be established and attained considerable success in the early years, many other institutions adopted the plans and policies of the Michigan college. All such institutions required manual labor. The teachers in charge of manual labor at these institutions, while recognizing the difficulties of providing appropriate labor for so many students, nevertheless seemed to be generally of the opinion that manual labor was a valuable addition to the requirements for an agricultural training. President Oscar Clute of Michigan in his annual report says, "This system, begun with no experience, has grown with the Michigan Agricultural College and has become one of the strongest factors in its prosperity." President Fairchild of Kansas Agricultural College, writing of the advantages of manual labor says, "Not the least is the cultivation of respect for energetic effort and consequent appreciation of the actual toil needed in every kind of life. . . . Again this helps to develop that practical judgment which makes the efficient man in every calling." Professor Maynard of the Massachusetts Agricultural College, quoted in the Speculum of June 10, 1891, remarks that the best results will also be obtained in those agricultural colleges where manual training is an important part in the curriculum. In 1870 in the Iowa Agricultural College it was reported that the labor in that institution was "managed with great tact and skill." Dean E. Davenport in 1890 wrote, "This (student labor): is, without doubt, one of the most difficult features of our work and, withal one of the most valuable." There were, however, many who looked upon manual labor as a waste of the student's time. Among the objections offered by those holding to this view were that the labor was not educational. It was in no sense organized as a systematic labor exercise but that students were required to perform work needed for the successful conduct of the farm rather than to perform duties of special value to the student. It was not possible to find suitable tasks for the large number of students which finally enrolled in these institutions. The long vacations interfered with 
the educational features. Students themselves often objected to manual labor. They insisted that they came to college to study and learn rather than to perform ordinary farm tasks which they had performed on their own farms throughout their lives. There was another objection to the manual labor required as the number of students enrolled increased. The time of students was needed to attend classes and laboratories, and manual labor interfered with a well planned schedule of studies.

The writer of this article was himself in charge of the required student labor on the farm of the Michigan Agricultural College for a number of years and stoutly maintained for many years that manual labor by students was worthwhile. It did not, however, fulfill all the rosy claims made for it in the beginning. The majority of students were not opposed to the requirement. They received eight cents an hour for the work performed and the income was acceptable. But there was always a certain small minority of students who performed the manual labor requirement because they were compelled to do so. They had little interest in the work before them and little appreciation for any of its supposed advantages. It cannot be claimed that manual labor was valuable to such students. The requirement imposed very real difficulties upon the administrators in the colleges. There were at times 150 students reporting to the Farm Department each afternoon at one o'clock and appropriate tasks must be found for these students who worked only two and one-half hours each day. This was a real problem and it must be admitted that at times students were required to perform tasks which were: neither educational nor essential.

It is clear that the labor requirement profited some students more than others. It is doubtful if the ordinary farm boy needed or profited greatly from the labor requirement. The rich men's sons from the city, attending these institutions in considerable numbers, in many cases because of the labor requirement, not only had a new experience but actually learned how to work. It often resulted also in accomplishing what some proponents of this plan believed would be accomplished, namely, developing a respect for skills in farm labor. The rich city boy was inclined to look down upon the awkward, crude, farm boy. In all social affairs the farm boy was at a disadvantage. But when the city boy and the farm boy were assigned to the task of cutting corn by hand or shocking wheat or milking cows, the city boy was at a great disadvantage, while the country boy performed most of these labors with ease and skill. Many strong friendships developed as a result of the associations of these two classes of students in the early agricultural institutions. In the writer's opinion there is a place for the development of skills in connection with many practical, agricultural subjects but no student should be paid for developing his talents in this direction.

The directors of agricultural colleges in the early years were un. doubtedly greatly influenced by the successful manual labor schools,. 
notably Fellenberg's at Hofwyl, Switzerland from 1806 to 1844 . A number of manual labor schools were organized from 1819 to 1830 in Connecticut, Florida, Maine, Massachusetts, New Jersey, New York, North Carolina, Ohio, Pennsylvania and South Carolina. Some others required manual labor in the early years of their experience. Colleges of agriculture were undoubtedly influenced in their curricula by the successful accomplishments of these schools.

Gradually the requirement of manual labor was eliminated from the curriculum of the land grant colleges. The practical difficulties seemed to outweigh the advantages so that today (1940) there is not, so far as the writer has knowledge, a land grant college in the United States that requires manual labor for which the student is paid. There is much student labor performed in agricultural colleges but such student labor is for self support. It is commonly based on the needs of the institution and the payment bears some relation to the ability of the student. This labor often has a real educational value but it is not organized primarily as a laboratory exercise. We have still to learn how more efficiently to use farms, orchards, gardens, livestock and other expensive equipments of these institutions as real laboratories and not merely as demonstrations of good farm practice.

The question is still unanswered as to how a young man with no knowledge of agriculture or farm practice can become really proficient in farm practice in an educational institution. It is still true that the most successful place for learning farm practice is on an actual farm. There are yet to be developed successful farm practice schools for students who have not been farm reared and who are almost totally ignorant of the manual labor required for the successful conduct of a farm.

\section{THE AGRICULTURAL MOTIVE}

No one fact stands out more prominently than that the land grant college owes its real character to the continuing desire of both the federal and state governments to serve agriculture and rural people. This service is being rendered through or by means of education. It is in some ways a remarkable testimonial of the faith of the American people in the potency of education for improving the economic and social conditions of the common people. It is very doubtful if the federal government could have been influenced to make grants of land for education in general or for any other special type of education in 1862. It is true that the law itself specifically provides for agriculture and mechanic arts, including military tactics and not excluding other scientific and classical studies. But the law is very specific in requiring that it shall be the leading object to teach agriculture and mechanic arts, even though its provisions were broad enough to include all subjects then included in the curricula of socalled "literary colleges". 
It seems to us now, after seventy-five years, that the provision for not excluding classical and scientific subjects was a concession to a not inconsiderable opinion in Congress that the best education, even for a farmer, was the education which was then universally offered in the established colleges and universities of the country. In order to insure the passage of the bill, it was probably necessary to suggest that these institutions would not entirely abandon the accepted programs of education then current.

President J. K. Patterson of Kentucky has emphasized the great contribution of the agricultural motive in an address delivered before the Association of Agricultural Colleges and Experiment Stations in 1901. He says, "Agriculture and the mechanic arts occupy an equal position in the Act of 1862 , but as a matter of history, it was agriculture which carried to victory the common cause of all industrial education."

Another provision of the bill was clearly a product of the particular emergency of that time. Military tactics were to be taught. The country was in the throes of a civil war. Trained officers and soldiers were needed. Here was a nationally endowed group of institutions, one in each state, that could be required, if approved by the state legislature, to give instruction in military science. As the result of this requirement, these institutions have throughout their history trained and graduated thousands of young men who can be called upon in an emergency to defend the country from outside aggression. This particular national service is of very great importance and has been too little emphasized.

As further evidence that Congress intended that these institutions should serve agriculture and rural people, we have only to trace the later legislation providing funds for these institutions. Congress has approved eleven major acts appropriating funds to colleges of agriculture and mechanic arts. Each of these is for agricultural teaching, research or extension. Four refer to the original Morrill legislation, and the funds available in these acts permit the use of funds for both agriculture and mechanic arts. The remaining seven bills are specifically for agriculture and rural life. Four are for agricultural experiment stations and three are for agricultural and home economics extension. For convenience these may be classified as, (1) for college teaching, (2) for agricultural experiment stations, and (3) for agricultural and home economics extension.

There is running through all this legislation the expressed will of Congress that the land grant college was to serve agriculture and rural people. Every appropriation for agricultural experiment stations was for using science to serve agriculture. Every extension appropriation was made for the purpose of extending the knowledge and influence of the land grant college to farmers and farmers' families. The provision for home economics extension seems to have been intended for farm homes. 
The provisions of the several Morrill acts and the later BankheadJones Act permitted the use of the funds appropriated for agriculture and mechanic arts. Administrators have interpreted mechanic arts, the term used in the original Morrill law, as synonymous with engineering. It has, therefore, been customary to pay salaries of engineering instructors from Morrill funds. This is undoubtedly legal and has resulted in encouraging the development of schools of engineering in connection with the land grant colleges.

These colleges are a definite part of the national plan and should be further developed. It is highly important for the nation as well as for the completion of the land grant college system that Congress provide for engineering experiment stations and thus serve the industrial classes in the same manner as the agricultural experiment stations have served agriculture and rural people.

In the earlier experience of these institutions some attempt was made to establish the principle that what Congress really intended was to have taught mechanic arts as related to agriculture; but a careful study of the laws for teaching clearly indicates that the Congress intended that these institutions should serve not only agriculture but also the "industrial classes".

It is interesting to note that while the Morrill Act of 1862 permitted the use of funds for teaching classical studies, this provision was not included in the second Morrill Act of 1890. The latter law is much more restrictive and definite in its requirement that the funds be used for teaching subjects "with special reference to their applications". While it has been and still is entirely legal to use the funds arising from the original land grant for classical studies it is nevertheless true that such does not conform to the spirit of the law.

The separate colleges of agriculture did not organize classical departments and were not, therefore, tempted to pay the salaries of professors of Latin from Morrill funds.

At the present time (1940) it can not be claimed that the separate land grant college has any advantage either in the breadth of its program or quality of its work. There are many obvious advantages in having a college of agriculture associated with strong departments of liberal arts, law, medicine, education, engineering, etc., such as is the case in the land grant universities. There is, after all, an important advantage in being associated with an institution where the encouragement of pure scholarship for its own sake is a major educational objective.

The present trend of the separate college of agriculture and mechanic arts is quite obviously in the direction of ultimately developing an 
educational program quite paralleling that of the state university. Most separate colleges of agriculture and mechanic arts are now legally designated as state colleges authorized to confer college degrees identical with those conferred by the universities. Most of the state colleges nof include practically the same divisions as the universities, excepting law and medicine. 


\section{SOME EDUCATIONAL INFLUENCES OF THE LAND GRANT COLLEGE MOVEMENT}

The Morrill Act of 1862 and acts supplementary thereto, including the series of appropriations for agricultural experiment stations and agricultural extension services, are to be regarded as the most important federal legislation for the promotion of higher education in the United States up to and including the year 1940. The success of these institutions endowed by the federal government established the important governmental policy of aid to education. As we have seen this policy was sharply criticized at the time of the passage of the Morrill Act.

There was even an attempt made to argue that such use of federal funds was unconstitutional. But these institutions, organized as they have been, one in each state cooperating closely with the public whose needs they attempt to serve, have abundantly demonstrated the soundness of this policy.

The provisions of the Morrill Act gave the stamp of approval for Congressional support to college education. The law specifically stated that colleges of agriculture and mechanic arts were to be established. Thus Congress made its first important contribution to education for institutions of higher learning.

It is, of course, true that the major influence of colleges of agriculture has been with rural people. The great majority of the people of the United States were engaged in agriculture in 1862. As a class they were very skeptical of education. They were more than skeptical of higher education. There is now no doubt but that the colleges of agriculture greatly influenced the thinking of farm people toward education as a result of the educational program conducted by these institutions. This was particularly true of higher education. From an attitude of scorn and skepticism of college education, the farm people of America have come to regard higher education in college as a valuable enterprise and worthy of support.

This is not only an asset of great value to these colleges, but it is a contribution to the appreciation of higher education and of scientific research in general. This education of the largest and most conservative group in our population to the real values and possibilities of scientific research is reflected in a changed attitude by federal and state legislatures and in the great development of science in the colleges and universities.

The education given in the colleges of agriculture and mechanic arts proved beyond question that practical education in a college was possible. As a result of their long struggle to develop satisfactory courses of study, other types of practical education, in the state universities particularly, but now generally in universities and colleges, have been organized with success. The successful inclusion of practical subjects in the college curriculum has undoubtedly been re- 
sponsible for the widespread interest in the introduction of vocational subjects in high schools.

There remains to be mentioned perhaps the most important influence of all which has been the development of public interest in scientific study. From the very beginning these institutions have based their curricula primarily upon science. They have employed the scientific method in all research. They have provided a training opportunity in scientific methods and research. The science teaching and scientific research in the higher institutions of learning have received great impetus from the work of the land grant colleges and universities.

The organization and administration of graduate schools has been influenced by the programs of work in the colleges of agriculture. The completeness of the equipment and facilities for research in the agricultural experiment stations have made possible substantial contributions to the general field of graduate study.

The state university of 1940 is all-inclusive in its program of intellectual enterprise. All knowledge with emphasis on useful knowledge is to be found in the curricula of these institutions. The relation of science to agriculture including almost every field of scientific research today has resulted in greatly broadening the educational program and enriched the curricula of the American college and university. It may be said without exaggeration that the modern university has come to be a depositary of all knowledge and is interested in all education. It is to this development that the land grant college and university have made a major contribution.

We may say, therefore, that the land grant college has demonstrated the beneficent policy of federal aid to education; it has won the enthusiastic support of the most conservative and perhaps skeptical class in our civilization to the benefits of college education. It has popularized science and proven its value in the common affairs of life. By so doing, it has greatly increased the public appreciation of the value of research in our rapidly developing civilization.

\section{MEASURING LAND GRANT COLLEGE RESULTS}

One measure of the scope and influence of an educational institution can be shown by statistics. This, when taken alone, is not a complete and altogether satisfactory index of educational achievement, but other things being equal, it does give us a rather true picture of the broad influence and nation-wide extent of the land grant college. Many persons have come to associate in their minds the name land grant college with the college of agriculture. There are various reasons for this. In the first place these institutions differ from the ordinary college and university in having a college of agriculture in their organizations. The division of agriculture is in every respect co-equal with arts and science, law, medicine, and other divisions. The college of agriculture has essentially the same re- 
quirements for admission, a four-year requirement for graduation, and confers an equivalent degree. In the second place, it is the colleges of agriculture that have organized the important sub-divisions of agricultural experiment stations and agricultural extension services. It is the work of these two sub-divisions that has given power and influence to the land grant college. It is through the work of these sub-divisions that the public has come to know and appreciate the educational effort of these institutions. In the third place, it is the college of agriculture and its experiment station and extension service that has enjoyed the continued favor and support of the federal government. The most substantial appropriations of Congress for education during more than seventy-five years have been for agricultural education or experimentation. It is the college of agriculture that has given to the land grant colleges their unique character, and nation-wide approval. But the great educational influence and leadership of these institutions is not by any means limited to their contributions to agricultural education, great as these have been.

It must be remembered that the land grant colleges and universities include colleges of arts and science, engineering, education, journalism, law, medicine, business and public administration, and almost every other intellectual discipline appropriate to a university. Each of these divisions has made outstanding contributions to the training of youth, the discovery of truth, and the general advancement of knowledge.

What, then, is the present day picture presented by these institutions? The latest report of the United States Office of Education, covering the year ending June 30, 1938, is authority for the following statistics. In this report 52 land grant institutions for white students employed 25,443 men and 16,421 women. There were enrolled as students in these institutions 167,139 men and 67,802 women; a total of 234,941 students. Of this number 20,304 were enrolled in graduate school. If we add to the above the student enrollment in 17 negro land grant institutions, we have a grand total of 245,642 students.

It is interesting to note the distribution of the students in divisions of land grant colleges. Arts and sciences enrolled 35.7 per cent; engineering 18.3 per cent; agriculture 12.0 per cent; teachers college 8.4 per cent; commerce and business 7.7 per cent; home economics 6.0 per cent; law 1.6 per cent; medicine 1.9 per cent; and others 4.5 per cent. The annual income for educational purposes of 69 land grant colleges and universities was $\$ 151,841,248$. To this there should be added $\$ 47,176,304$ designated during the same period for increase of permanent funds, physical plant, and other enterprises. This large annual income of approximately $\$ 200,000,000$ for higher education in state and federal supported institutions is a fact of the greatest educational significance in our American democracy.

It must be pointed out that a large proportion of the funds expended directly for the support of the colleges of agriculture is for agricul- 
tural experiment stations and for agricultural extension services. It is the work of these subdivisions that gives to the college of agriculture its unique position among the other divisions of the landgrant college or university. Thus far no other school or college has approached the college of agriculture in respect to its scientific and educational service to people non-resident at the institution. These two sub-divisions are closely correlated and each in its respective field has contributed to the success of the other. The agricultural and home economics extension project represents one of the most extensive and effective enterprises for adult education that has ever been undertaken by this or any other government of modern times. The agricultural experiment stations and the United States Department of Agriculture together constitute the greatest organization for agricultural research in the world and this organization is one of the most extensive and effective agencies for the advancement of science in the United States.

It would be a great mistake to measure the achievements of the colleges of agriculture and the experiment stations solely by economic results or monetary standards. One of the most significant results has been to enlarge the intellectual horizons of rural people. Agriculture has in a real sense come to be an intellectual vocation in which knowledge is an essential and primary factor. This knowledge is in most part new knowledge as opposed to historical or traditional knowledge and is based upon scientific research. This has proven to the farmer that his success is dependent quite as much upon a keen intelligence as upon the traditional rural virtues recognized for generations as essential for a successful rural life.

\section{UTILITY MOTIVE IN EDUCATION}

The principal of utility as a motive in higher education met widespread opposition, as we have seen, from the leaders of university and college education in 1862 and for many years following. In the present practice, however, of all institutions of higher learning there is abundant evidence that the utility motive is today a major influence in university training.

Dr. S. P. Capen, chancellor of the University of Buffalo, stated in 1929, "Look now at the great university organizations of the country and what do you see? Engineering, agriculture, forestry, commerce, home economics, education, the great health services-these hold the front of the stage. They attract the bulk of the students. They absorb the major part of the appropriations. They carry the institutions reputation. Indeed, the distinctive contributions of America to higher education, and the contributions which are recognized throughout the world, have been made in this once despised field of technical education."

The land grant college must be given chief credit for accomplishing this revolution against heavy odds. As Dr. E. A. Bryan, formerly 
president of Washington State College, said concerning the advent of the land grant college, in a memorable address before the American Association of Land Grant Colleges and Universities in November 1931, on the subject "The Spirit of the Land Grant College", "It was the beginning of a revolution, whose full force is not yet spent. It has been a revolution in the means or instruments of higher education, in the methods employed in the purposes of those who seek it, and in the community that provides it. Moreover, its charter marked the practical beginning of a system of education that is truly national-the joint undertaking of federal and state governments to establish and maintain cooperatively educational agencies which should meet the national need. . . . This revolution involved a "change from language as a basis to science as a basis; from the study of words to the study of things; from a verbalistic to a scientific system of education."

\section{CONTRIBUTIONS TO ECONOMIC LIFE}

The important contributions of the land grant colleges and universities, especially in the field of rural affairs, is one of the outstanding educational achievements of modern times. The leadership of these institutions in the development and progress of agriculture and rural life have indirectly had a profound influence upon the public welfare. Agriculture is a basic and essential industry. Agricultural people constitute the very foundation of our American democracy. Our agricultural resources are the greatest and most important.

These institutions have had a significant influence upon the economic life of our country, upon the social and intellectual lives of rural people, and they are generally recognized to have had a very great influence upon the development of modern education. The economic welfare of farm people has been a major motive in the development of these institutions.

The farmer more than any other individual in our civilization deals directly with the elemental forces of nature. $\mathrm{He}$ is helpless in the face of soil conditions, weather, plant and animal diseases. The rains are both a blessing and a curse. Seasonal rainfall brings an abundant harvest: excessive rainfall results in erosion, and enormous Iosses in soil fertility; the topography of the land, which he works, may be favorable or unfavorable to these vast elemental phenomena which make the cultivation of the soil easy or a task of enormous difficulty.

It is in connection with these elemental, natural phenomena that the colleges of agriculture have made their greatest contribution to agricultural production. By solving the problems or soil erosion and other soil losses, by the improvement of plants and animals, the prevention and control of animal and plant diseases, improvement of agricultural products, and by extending the knowledge of physical 
and chemical properties of soil as related to fertility, these institutions have reduced the amount of labor required for each unit of production and greatly increased the income of farm people.

In the 1928 survey of these institutions by the United States Office of Education it is estimated that a total of $\$ 800,000,000$ was added to the wealth of farmers in one year traceable directly to the activities of the college of agriculture. There are other evidences of economic gain to be found in the results coming from the efforts of these institutions. One measure of such increased economic gain is to be found in the value of farm property. In 1850 the total value of all farm property in the United States in round numbers was $\$ 4,000,000,000$; in $1870, \$ 11,000,000,000$; in $1900, \$ 20,000,000,000$; and in $1930, \$ 50$,$000,000,000$. This increase of more than $300 \%$ in the value of farm property is to some extent traceable to the improved economic methods developed by the colleges of agriculture. Moreover, the efficiency of each farm worker was increased during the period 1870-1930 more than two and one-half times.

In spite of the efforts of the land grant colleges, and in spite of the greatly decreased cost of production from the efforts of the agricultural experiment stations and extension services, agriculture and farmers have suffered more than other economic groups from the great depression following the World War. This depression resulted from a number of complex factors such as the decrease in the demand for agricultural commodities in foreign countries, embargoes, quotas, the greatly increased cost in distribution of agricultural commodities, and changes in the monetary standard. All of these factors which seem to have been primarily responsible for the great depression are wholly outside of and apart from the educational endeavors of the colleges of agriculture. We may well wonder, however, if the increased knowledge and improved practices developed by the colleges of agriculture, experiment stations, and extension services did not actually prevent a total agricultural collapse following the World War.

The direct contributions of the college of agriculture to the economic life of the nation can in a few cases be fairly estimated. The indirect benefits and gains to agricultural production, manufacturing, commerce and to the consumer are incalculable. They transcend any statistical method now available. But they are fully recognized and appreciated. If further evidence of this approval by all classes in our economic structure were necessary, we need only point to the enthusiastic approval of rural people, of chambers of commerce, industrial corporations, transportation companies, and others. As a result of the interest of these groups, there has resulted an unequivocal and enthusiastic attitude of the Federal Congress and the state legislatures in appropriating funds in larger and larger amounts for continuing and expanding the work of these institutions. 


\section{DEVELOPMENT OF INTELLECTUAL RESOURCES}

No one now questions the important contributions made by colleges of agriculture to the conservation and development of our natural resources, in particular those which relate to the soil and its products; but we must, I think, also credit these institutions with significant and greatly important contributions to the intellectual resources of the United States. After all, the human and intellectual resources of the nation are of greater importance to its development and stability than are its natural resources. It is clear from the discussions before Congress during the passage of the Morrill Act that these national colleges were intended to provide a means for the intellectual and social development of the industrial classes. These had been generally neglected in the scheme of higher education in the United States before 1862. It was a clear recognition of the fact that there were intellectual resources among the masses of our population. These resources could be developed to the advantage of the nation. The theory that higher education was for the favored few was untenable in the American democracy. The door of opportunity for education must be open to all. The specific type of education required of these institutions was a means to the end, which was and is the intellectual and social progress of the industrial classes. The experience of these institutions over a period of seventy-five years has justified the faith of the founders. We cannot measure the full extent of the influence of these institutions upon the intellectual life of the thousands of students who have received their education in these colleges, but it is very great.

\section{SOCIAL CONSEQUENCES}

There is no educational process but that has its social consequences. The more people concerned and the more widespread the extent of such education, the greater the consequences. All education has for its objective the amelioration of unfavorable conditions surrounding human beings and the increase in the sum total of human happiness. We may well ask ourselves the question whether the land grant college movement in the United States has resulted in ameliorating the conditions of the rural people, and increasing their happiness.

It is claimed that agricultural teaching and research have too lightly regarded the social consequences of their work. There is some foundation for this charge. The immediate problems crying for solution have been production problems. The first step in the solution of the rural problem is to increase the farmer's individual income. In the effort to accomplish this purpose, the institutions concentrated, in the beginning, on the problems of production.

But any unprejudiced observer of the present activities of the agricultural experiment stations and the teaching of the colleges and the activities of the agricultural extension service must be impressed 
with the great attention being paid at the present time to the social sciences. It cannot now be said that these institutions are neglecting the problem of the social consequences of their work. It is to their credit that they themselves were the first to sense this and by united action secured the passage of the Purnell Act in 1925. For the first time in the history of the land grant colleges there were provided federal funds for a direct investigation of economic and social problems. This bill, while authorizing all types of existing agricultural research, specifically states "and including such scientific researches as have for their purpose the establishment and maintenance of a permanent and efficient agricultural industry, and such economic and sociological investigations as have for their purpose the development and improvement of the rural home and rural life." Thus the federal government itself placed the stamp of its approval upon social studies, and as a result, great development has taken place in every institution in the country. It is, perhaps, still too soon to measure accurately the results of this legislation and its consequent impact upon rural life, but if the researchers in social science make as great a contribution to rural social welfare as has been made to the efficient management of farms, then we may confidently expect a similar improvement in social well being to rural people. There is no less need for technological research and teaching but there is great need of an advance all along the line in rural social research.

In attempting to evaluate the influence of the land grant college movement upon education in general, we must not overlook certain factors of importance. Consideration has already been given to some of these factors. The revolutionary philosophy embodied in the land grant college movement was not born full-fledged in the brains of the intellectual leaders of 1862.

It is well again to call to our mind the fact that science was in its infancy in 1862. The industrial revolution had barely begun. There was definite opposition to science in the established institutions of the day. There was even greater opposition to any idea of vocational training and definite antagonism toward the land grant colleges.

It required half a century of determined effort on the part of these institutions to establish the fact that higher education might be a valuable training for all men, that knowledge for use was after all a legitimate educational motive. While these institutions have not yet been accepted into full fellowship with their colleagues in the liberal arts colleges, they have nevertheless won a definite place in the educational field.

It is, I think, clear that the land grant college has made contributions to education in general in at least the following respects.

1. They have proven that higher education may be useful as well as ornamental.

2. They have greatly developed and improved the laboratory method of instruction. 
3. They have developed a curriculum based upon scientific research.

4. They have broadened and enriched the college curriculum.

5. They have proven the worth of federal aid to higher education.

6. They have accomplished a practical and successful system of federal state cooperation in education which may be a model for all future federal state relations.

President Winthrop E. Stone in 1912 before the Association of American Agricultural Colleges and Experiment Stations said, "The establishment of these institutions has brought the application of scientific principles into the commonest occupations; emphasized the democracy of education; established the status of tax supported institutions of higher learning; and more than any other cause, contributed to the development of the new education in America. Now at the end of fifty years, the land grant colleges with the experiment stations and the departments of agricultural extension, constitute the most unique, useful, appreciated, and popular group of educational institutions in the country. . . .

"The land grant colleges are no longer inconspicuous and uninfluential. In most states they are not only the authority on agricultural and related industrial matters, but they have large influence educationally. Their responsibilities are, therefore, very great and their attitude or action of vast significance in their respective communities."

President W. O. Thompson of Ohio State University in an address before the Association of American Agricultural Colleges and Experiment Stations in 1912 said. "To sum up: the influences of the land grant colleges upon higher education would, among other things, include the following:

"First, they have greatly stimulated the interest of the people in higher education as manifested by unparalleled appropriations. . . .

"Second, the debates clustering about the passage of the land grant act, coupled with the experience of the colleges, have set a precedent and proved the wisdom of federal aid to education.

"Third, the experience and history of these colleges have brought industrial education to its rightful place in the esteem of the American people and have forced its recognition by all institutions for higher education. . . . The State's right to maintain education in all fields of study is unquestioned.

"Fourth, the land grant colleges, not exclusively to be sure but efficiently, have influenced the practical aims of higher education by insisting upon a larger liability in the programs of education and in the content of the course of study.

"Fifth, these institutions have stimulated investigation and research in many fields.

"Sixth, while not specifically related to the topic of this paper, I cannot refrain from suggesting that influence of these colleges upon the government itself has had something to do with the cause of higher education. Everyone recognizes that for a hundred years we have 
had a progressive interpretation of the constitution under which we live and that the interpretation has tended steadily toward enlargement of the powers of government. This enlargement has chiefly been in the interest of the people. The old theory of limiting the government to police powers only has been found inadequate to the needs of a great people."

Dean E. Davenport of Illinois before the American Association of Agricultural Colleges and Experiment Stations in 1912 remarked, "Nothing was more natural than that the agricultural college should in general develop into a state university, the commonwealth supplementing from its own funds the several grants from the Federal Government. Where this has occurred the entire institution has partaken of the initial purpose of the agricultural and mechanical college; namely, to serve the state by developing every subject of interest and value to a highly civilized commonwealth, in which instruction to students is an incident to the general purpose, a means to an end, which is the development of the state. To this end, research and extension work are recognized as equally important with undergraduate or even with graduate instruction."

Educators recognize the value of discipline in education. The disciplinary motive has been a major consideration in the educational philosophies of a century. While the land grant colleges accept the thesis that intellectual discipline is an important factor in education, they do not admit that it can only be utilized in the study of classics and the humanities. As President A. Ross Hill has said (in 1923), "The gradual encroachment of the sciences and other modern subjects in the colleges in the latter half of the nineteenth century led to the elective system and the abandonment, to a large extent, of this disciplinary basis of education; while vocational curricula have multiplied in response to new social and economic needs and in keeping with the increasing applications of scientific knowledge to the affairs of everyday life."

There is abundant evidence that the colleges of agriculture have won appreciation of a great people to the real value of education. This has directly benefited all education. All types of higher education today are receiving larger apropriations because of the services performed by the colleges of agriculture. The college of agriculture has builded the foundation for a new educational philosophy. Its influence permeates all education. Education for use based on the necessities of a people now characterizes the program of every high school, every college and every university in the land. This revolution in education was the inevitable consequence of democracy itself and would have eventually prevailed, but, we must in all fairness admit that it was the land grant college and university that initiated this revolution and struggled against great odds to maintain its essential value for a very long period of time. After seventy-five years these institutions look upon an educational system which really serves our 
democracy. It has become in a very real sense a preparation for life's work. It deals with the problems of today. It is the American way for conserving our human resources.

\section{DEMOCRATIZING EDUCATION}

It is claimed for the land grant college that it has democratized education. This democratization of education has been accomplished in two ways: first, it has broadened the curriculum; and second, it has made it possible for students of limited means to profit from higher education. The land grant college is a direct challenge to the idea that higher education is for the privileged few. It is clearly in the interest of our democracy that higher education should not be limited to those only who are able to pay a high price for a college education. The land grant college welcomes the admission of students of intellectual capacity regardless of their social or economic status.

Low tuition fees alone will not attract students. The land grant college has a brilliant record of attracting students by reason of the subjects taught. The large and increasing enrollments in these institutions through a very long period indicate that, after all, it is the instruction offered that interests students and it is not to be found in the student's costs of attendance.

The land grant colleges and universities were probably the first institutions of higher learning to recognize the national need of conservation of our natural resources. Important as this recognition on their part has been, an even greater one has been their contribution to the conservation of human resources. The intellectual resources of this nation are not confined to the wealthy. It may indeed be true that the greatest source of intellectual capacity is to be found in that very much larger group in our civilization whose economic resources make it exceedingly difficult and burdensome to provide a college education for their children. Other things being equal, therefore, the college or university that provides a thoroughly sound college curriculum at a reasonable cost is making a real contribution to the conservation of America's human resources.

Those colleges and universities which for any reason continue to increase the cost of higher education are by this means preventing a very large group of intellectually capable students from securing a college education. Obviously only institutions endowed by the federal and state governments are able to provide a low cost college education. The older endowed institutions of higher learning in the United States followed rather closely the English system which was and is to educate an aristocracy. This aristocracy in England has been and still is the ruling class. In a country where the class system is so pronounced as in England, this ideal of education is satisfactory, but apparently one result is to still further accentuate the class system and to widen the breach between the educated aristocracy and the great middle class. 
It is difficult to harmonize this philosophy of education with our American system of democracy. If it is true that it does tend to perpetuate the class system and to limit the benefits of education to the privileged few, it is contrary to the ideals of American democracy. It also fails to develop the intellectual resources of a very large group of middleclass and low income people. Clearly it is in the interest of the public welfare to develop such human resources in a democracy and to continue to keep open those channels of intellectual and social opportunity which have in the past been the boast of our American democracy.

It was Thomas Jefferson, writing to Cabell in 1815, who evidently had this important principle in mind when he wrote, "Culling from every condition of our people the natural aristocracy of talents and virtue and of preparing it by education at the public expense for the care of the public concerns." It is here that the land grant colleges and universities of the United States have made a very great contribution to our national welfare. The land grant colleges have been fortunate in the quality of students admitted. In most part, the students in colleges of agriculture have been farm boys and girls. They have come to the college with an intellectual equipment which is the heritage of all farm reared children. They have received a certain discipline in the labor of the farm and have developed a certain ruggedness of character which is a valuable asset in student and later life.

Great men have come from such environment; Pasteur was the son of a tanner; Faraday's father was a blacksmith; and Pupin, a farmhand. And institution that gives encouragement to the development of the intellectual resources to be found in the humbler walks of life is serving our American democracy.

These institutions too have perhaps come nearer to realizing certain modern educational ideals. The college curriculum and the training received is very definitely based upon or correlated with the early experience of the boy on the farm. In no other curriculum does the college course so definitely relate to the knowledge and experience gained before coming to college. This is not to say that young women and young men from urban environment do not come to the colleges of agriculture and do not receive training that is worth while. But in most situations requiring leadership in rural affairs, the agricultural background of students is valuable and important.

Perhaps no educational institutions have cooperated so closely with the group for whom the education is intended. The colleges of agriculture have maintained a very close contact with the rural people. It is not incorrect to say that the conduct of the curriculum of the colleges of agriculture has been influenced by the rural people themselves. Agricultural education is based upon agricultural need. It has provided an intellectual basis for an age old industry. It has provided an intellectual interest for rural people. The educational 
needs of a national industry have influenced importantly the policies of these institutions.

The land grant colleges and universities have encouraged the democratization of education in other ways. They have provided a favorable environment for many subjects of immediate interest and utility. It was in these institutions that home economics had its first important development and in which this subject has found a friendly encouragement. Even before the development of home economics courses, the land grant colleges have from the beginning been coeducational. Women have been admitted to these institutions on an equality with men, and such admission of women was not generally encouraged in 1862.

\section{FEDERAL RELATION TO EDUCATION}

One of the most frequent arguments in Congress in opposition to the several Morrill Acts was that the bills definitely provided for federal control of education. True this bill was limited to education for agriculture and mechanic arts but it was argued if the government could prescribe the objectives of education in this field it could similarly determine the educational policies of education in general. Such a relation of the federal government to education was unwise and altogether contrary to the philosophy of democratic control of our educational institutions. The states and local communities should have independent and complete control of the local schools.

These arguments are still current. Probably most of the leading educators of the United States fear federal direction, proscription, domination or control of public education. Dr. Isaiah Bowman, president of John's Hopkins, in a recent report issued a warning to educational institutions against federal control of education "and ensuing deadly uniformity of indoctrination to suit the government of the day." In similar vein Dr. Nicholas Murray Butler suggests the dangers of a "type of despotism" under which free education would be stifled. "The duty of universities is the education of public opinion to the end that it will be alert . . . open-minded

fair . . devoted to social, economic and political liberty for all men."

It is difficult to see how federal aid to some kinds of education can be regarded as a danger to democratic institutions. Such types of education as are clearly for the conservation of our natural resources and their development are certainly in the interests of all the people as well as the permanence of the government itself. Broadly conceived, the colleges of agriculture were established for this very purpose. Our greatest and most permanent national resource is the soil. The soil cannot be destroyed. It can be exhaused by unintelligent use, but nature has provided within the soil itself and the air above the means for renewal of its productivity. We now know as a result chiefly of the research in these colleges of agriculture that this 
exhaustion can be prevented and if it occurs it can be restored. There may be types of education which should not be controlled by the federal government. There may be a kind of teaching which if controlled by the federal government would endanger individual freedom and the search for truth. But research, an element in all education, is so important a means of solving the problems of government outside of and apart from social or political considerations that the nation cannot safely ignore a method so important to our modern civilization.

But in spite of these warnings and because of real need for larger endowments, probably most institutions of higher learning and their eminent administrators could be induced, without too much pressure, to accept federal funds for education. In support of this view the congressional record covering the deliberations of the Seventy-Fourth Congress, and indeed almost every Congress in recent years, is testimony to the fact that educational leaders have struggled valiantly for years to secure federal funds for education. These efforts have not been limited to requests for elementary and secondary schools but numbers of bills have been introduced which provide for federal appropriations to colleges and universities. The majority of the bills embodying these requests are for special kinds of education or research.

Congress, so far, has limited its grants for higher education to the original land grant colleges and universities founded by the Morrill Act of 1862. The Congress by its continued support of these institutions seems to have accepted the view of Senator Morrill in his arguments for the approval of this legislation on the grounds that these colleges are national colleges and as such have a special relation to the federal government, such as is not enjoyed by any other institutions. There is also the apparent feeling in Congress that these institutions have faithfully recognized their national obligation by reason of their federal origin and are serving the national purpose.

For seventy-five years the land grant colleges, cooperating with the federal and the state governments, have abundantly proven their value from the national point of view. They have been "alert", "openminded", and "devoted to social, economic and political liberty for all men". And this in spite of, or maybe because of, their support by and relation to the national government.

These institutions are a living example of a rational federal state cooperation in education which may point the way to similar procedure in future developments of federal relations to other types of education. There is no evidence of indoctrination in the seventy-five years of their existence.

What, after all, are the real dangers to be feared from federal appropriations for public education? Clearly the federal government has an interest in public education. No one can deny this in- 
terest. Democracy itself may ultimately depend more on education than upon any other single influence for its successful existence.

It then becomes a question of how can the federal government best cooperate with the states and local communities in this matter. Many would have the national Congress appropriate funds to the states without limitation and without restriction of any sort, leaving to state authorities all decisions as to administration within the state, subjects to be taught, arrangement of curricula, and all other matters generally involved in the terms "educational procedures" or "processes of education".

The federal government may well pause at so complete an abdication of authority in the expenditure of funds of federal origin. If the federal government has a sufficient interest in public education to appropriate large sums for its advancement, it must have an interest, it may be a vital interest, in the kind of education to be advanced by the expenditures of federal moneys. It is not inconceivable that some schools in some states might be responsible for teaching forms of government wholely un-American and which teaching might even result in rebellion against the government itself. We do not anticipate such use of federal funds but some limitation or restriction at this point may be essential. The chief difficulty in appropriating funds to the states for public education is, on the one hand, to avoid undue and unwise federal control, and on the other, to provide suitable protection to the government by appropriate administrative procedures.

It may not be inappropriate to inquire at this point whether all types of education are of equal value to the national government. Are there some types of education which should not be encouraged by federal grants? At any rate, it must be true that some education is of greater importance in the training of youth for citizenship than other education. Government funds are now and always will be limited. Would it be wiser for the federal government to finance those forms of education which it is agreed are of most importance? This principle has already received the approval of the federal Congress in appropriations to land grant colleges and universities and for vocational education in high schools. Experience with these federal grants has been generally satisfactory. The tax-paying public has indicated its enthusiastic approval and support of these grants.

We must avoid at all costs destroying or hampering the exercise of local initiative in education. We must avoid the dead hand of regimentation of education. The glory of the American educational institutions is their complete freedom and independence of political control. This freedom must be maintained even at the cost of the highest efficiency in administration.

Is it possible to continue to enjoy complete freedom from any kind of government supervision, or even control, and at the same time receive federal funds? Is it wise for the federal government to ap- 
propriate money for any purpose and not exercise such supervision as is necessary to insure that the funds are expended for the purposes for which the appropriation was made? President John J. Tigert* of the University of Florida, and former U. S. Commissioner of Education, in discussing "The Real Peril of Federal Subsidies" says, "Inevitably federal control must accompany federal support . . . you must either have federal control and interference or you must have misappropriation of funds and waste". We cannot escape the conclusion that federal aid to education in the states involves some federal control. The Congress does not appropriate money for any purpose without federal administration.

The mildest form of administration involves the machinery necessary to determine whether the funds appropriated have been wisely expended. It is not probable that such administrative direction or control can be relinquished to the state authority. It is in the public interest that the federal government should appropriate funds for public education. The states have not been able to provide adequate funds for an efficient public school system. It is important that all citizens be provided with reasonably adequate facilities for at least a certain minimum standard of education.

The problem for the states then is to decide whether they desire to have federal aid with federal administration. And further to decide what kind of federal control can be devised which will not interfere with local initiative and local support. Legislation for federal aid to education will be more likely to appeal to Congress if some effort is made to more clearly define the educational objectives in the minds of administrators. It should be possible to state the broad objectives in education even in a federal law. This was done by Congress in each of the appropriation bills for the maintenance and support of land grant colleges.

The experience of the land grant colleges in the expenditure of federal funds for education has not been of such a nature as to support the argument that federal administration is dangerous. Evidence is lacking of harmful interference with the states in the administration of these institutions. Local initiative has not been destroyed. The states have determined all major questions involving educational policies. The federal authorities do require, and properly so, a strict accounting of all expenditures.

The truly national character of the land grant colleges and universities is still further revealed in the fact that, from the beginning they have been called upon in cases of emergency by the federal government for special services.

During the World War one of the major efforts of the American government in the direction of preparedness was the production and distribution of food commodities. These colleges were immediately called upon to organize the farmers of America in a nation-wide production campaign which resulted eventually in supplying not only the

*Nation's Schools 1934. 
needs of our own military forces with an abundance of food but contributed great quantities of essential food materials to the allies. One result of this effort was that not only were the soldiers supplied with an abundant food ration but the civil population at no time suffered from a lack of the essential requirements of human nutrition.

A large number of the officials of these colleges of agriculture and mechanic arts, located in each of the states of the Union, became chairmen of state councils of defense and an even larger number were appointed by President Wilson as federal food administrators. These officials, responsible as they were for the administrative direction of agricultural research and agricultural extension in the several states, were in an especially favorable strategic position to accomplish a maximum of result with a minimum of cost and effort.

The wisdom of the founders in requiring military training in these federally established institutions was fully confirmed when it became necessary for the United States to enter the World War. The graduates of the land grant colleges were already partially trained to serve as officers. Their services in helping to weld together the millions of untrained men was fully recognized.

\section{MECHANIC ARTS IN THE MORRILL LAW}

The original Morrill Act of 1862 provided that the proceeds from the sale of land grants should be applied to the support and maintenance of colleges of agriculture and mechanic arts. In the beginning many separate institutions, founded under the Morrill Act, were officially designated as "Colleges of Agriculture and Mechanic Arts". In those universities and colleges in which colleges of agriculture and mechanic arts were located, there was organized in the beginning a division in the university in which both agriculture and mechanic arts were included. As these two types of instruction developed, these divisions were separated and eventually became colleges of agriculture and engineering.

It is interesting to note that the passage of the Morrill Act gave great impetus to engineering education. The great industrial and manufacturing developments in this country following the Civil War called for great numbers of trained engineers. Transcontinental railroads, great manufacturing establishments, with the later developments in electrical and mechanical fields were reflected in the increasing enrollments in engineering schools.

It is not too much to say as we look backward over the early years of the development of the land grant colleges and universities that engineering schools were more successful in the beginning than were the colleges of agriculture. They were fairly well supported by the state governments although it is to be observed that after the passage of the Morrill acts and amendments thereto, Congress has made no further appropriations for engineering schools. Their important 
progress and development seems rather to have been due to the generosity of the states.

Very sincere efforts have been made by the Association of Land Grant Colleges and Universities to secure appropriations from Congress for engineering experiment stations but so far, these have been unsuccessful.

\section{FEDERAL-STATE COOPERATION}

The passage of the Hatch Act not only resulted in a great impetus to agricultural research but "founded a system of federal state cooperation and research which has had far reaching effects within the half century since its inception." This federal state cooperation has had a profound influence upon the organization, correlation and coordination of scientific research in America.

The Hatch Act and subsequent legislation for the support and maintenance of Agricultural Experiment Stations requires certain duties to be performed by the Secretary of Agriculture. These requirements are chiefly in relation to the attempt to correlate and coordinate the results of research and to report upon the proper expenditure of funds provided by Congress. In connection with this provision of the original legislation there has developed a cooperative relation betweeen the Federal Department of Agriculture and the State Experiment Stations that is to be encouraged and in every way commended. Local initiative is preserved. The decision as to relative importance of local problems is left to the states. No attempt so far has been made to direct, control or dictate fundamental policies in the conduct of these institutions. The United States Department of Agriculture is itself the largest single scientific agency for agricultural research in the world. Very large sums are available from the Federal Congress for the important research projects conducted by the Department. The United States Department of Agriculture and the State Experiment Stations have developed a State-federal, cooperation in research on a national scale. The resulting correlation and coordination of nation wide results is unique in the history of scientific investigation.

\section{THE ASSOCIATION OF LAND GRANT COLLEGES AND UNIVERSITIES}

The rapid progress of the colleges of agriculture and mechanic arts has been importantly influenced from the beginning by the Association of Land Grant Colleges and Universities. Many conferences of representatives of colleges of agriculture were held, beginning in 1871; but not until 1887 was organized the Association of Agricultural Colleges and Experiment Stations. It continued under this name for thirty-two years. The name itself was evidence of the importance of agriculture in the educational program. The association has come 
to have a very important place in the educational movements of the United States and, in particular, the land grant college movement. Its membership includes representatives of every white land grant college in the United States. The object of the association as stated in the original constitution was "the consideration and discussion of all questions pertaining to the successful progress and administration of the colleges and stations included in the association." An examination of the proceedings during the first twenty-five years of this association indicates that the chief concern during that period was for the problems arising in connection with the colleges of agriculture and the agricultural experiment stations.

With the continued growth of the institutions, the number of representatives of colleges sent to these conferences increased until the association itself became somewhat unwieldy. It seemed also that other subjects than agriculture and agricultural research were more and more included in the programs. It was, therefore, a logical development that in 1919 the constitution was revised, first in respect to the name, and second, the plan of organization of the convention. The name was changed from that of "Association of American Agricultural Colleges and Experiment Stations" to "American Land Grant Colleges". The constitution was further revised to provide for appropriate sections of agriculture, engineering, home economics, agricultural teaching, experiment station and extension work. There was provided an executive body, limited in its membership to the executives, or their representatives, of the land grant colleges. The executive body was to be the legislative body and all recommendations from the sections were to pass through an executive committee.

An executive committee of five members was authorized; three of whom must be elected from the executive body, and two at large. At a later date the president of the convention was made a member of the executive committee. In practice this provision of the constitution resulted in the election of three presidents of institutions and two deans or directors. This form of organization and name of the association prevailed until 1926, at which time the name of the association was again changed to include the name "Universities" so that the complete name became "Association of Land Grant Colleges and Universities." Under this form of organization, the association has conducted its affairs since 1919. The purposes of the association have not changed but their duties and responsibilities have greatly increased.

The important relations of the land grant colleges to the federal and state governments and to the public welfare generally has given to this association a very important influence in the educational development of the United States. The present plan of organization provides an executive committee with full authority to represent the institutions during the time when the association itself is not in 
session. The business of the association is conducted chiefly through standing committees. The reports of these committees in the proceedings from 1887-1940 undoubtedly include the most important educational pronouncements relating to the history and development of these institutions.

These standing committees in 1939 were as follows: college organization and policy; instruction in agriculture; instruction in engineering; instruction in home economics; experiment station organization and policy; extension organization and policy; military organization and policy; engineering experiment stations; graduate work; and committee on graduate work; also two joint committees with the United States Department of Agriculture, one on projects and correlation of research, and one on publication of research.

The term of office of these committees is usually three years. No committee is entirely changed in any one year. It will be seen, therefore, that these committees are continuing bodies thoroughly familiar with the basic policies of these institutions and able to give intelligent consideration to the educational problems involved. . . . The recommendations of these committees have had a major influence upon the educational policies, the form of organization and the generally recognized efficient administration of these national institutions.

The latest change in the constitution of the Land Grant Association was adopted in 1937 and provides for the election of an executive committee. "An Executive Committee of nine members, one of whom shall be the president and eight of whom shall be chosen by the executive body. The terms of the eight members shall be for four years, two such terms expiring each year." The association has thus provided for a small representative group which can be quickly assembled for the consideration of important policies and procedures of importance to these institutions.

From the very beginning the executive committee of the association has had a significant influence in promoting the interests of these institutions. This committee has represented the member institutions before the Department of Agriculture and Congress; it has had a determining influence on the policies of the land grant colleges and universities.

Perhaps, its most important contribution has been in connection with the federal legislation relating to the teaching, research and extension activities of these institutions. We have seen how it was largely through the influence of the teachers of agriculture that the second Morrill Act, providing a definite appropriation for agricultural colleges, was secured. The influence and support behind the original or first Morrill Act, 'granting land to the several states for the establishment of colleges of agriculture and mechanic arts, was primarily the result of the demand of farmers and agricultural officials other than agricultural teachers. There were very few agri- 
cultural teachers in 1862. The National Grange, the American Farm Bureau Federation, the National Farmers' Union and other agricultural societies have in recent years given loyally of their support and encouragement to these institutions. After the passage of the first and second Morrill Acts, however, it was the Executive Committee of the Association of Land Grant Colleges and Universities which formulated the legislation for agricultural research and agricultural extension. It was the executive committee of the association that attended the hearings of Congress on this legislation and presented the arguments for their passage. The committee was always ably and strongly supported by the farmers' organizations. In formulating this legislation, the interests of the states were protected, as far as they could be under our form of government, from the danger of federal domination. The purposes for which the funds appropriated could be used are much more clearly stated in the later legislation prepared by the Executive Committee. Dean M. F. Miller of Missouri speaking at the seventy-fifth Anniversary of the founding of the Kansas State College said, "There is in my opinion, one other explanation for the increasing support of Experiment stations and agricultural education . . . namely the activities of the Association of Land Grant Colleges and its enlightened leadership. The executive committee of this association has for years been made up of men of great ability and public spiritedness. To these men must go much of the credit for providing proper guidance and increased financial support for these great institutions."

\section{FEDERAL LAWS AUTHORIZING APPROPRIATIONS FOR LAND GRANT COLLEGES AND UNIVERSITIES}

The Land Grant Colleges and Universities are now operating under federal laws, each of which makes an appropriation for some specific purpose under certain administrative conditions. Each state institution must moreover comply with certain state regulations. In general it may be said that none of these laws, either federal or state undertake to determine educational policies or the subject matter, except in the broadest terms, or the means to be employed in accomplishing the objectives and purposes of the laws enacted. The federal laws, appropriating funds for teaching of agriculture and mechanic arts are the following:

\section{Funds For COLLEge TEACHING}

(1) The first Morrill Act granting 30,000 acres of land to each representative in Congress for the establishment of colleges of agriculture and mechanic arts.

(2) The second Morrill Act appropriating $\$ 25,000$ to each college for the same purpose but strongly emphasizing instruction in agriculture and mechanic arts.

(3) The so-called Nelson Amendment appropriating $\$ 25,000$ to colleges of agriculture and mechanic arts with the provision that a 
portion of the funds might be used for the training of teachers of elementary agriculture.

(4) The Bankhead-Jones Act which provides a total appropriation of $\$ 980,000$ to be paid annually in equal shares to the states and another appropriation ultimately of $\$ 1,500,000$ additional, allotted annually to each of the several states, "in the proportion which the total population of each state . . . bears to the total population of all the states." It is apparent from this law that some states will receive more than others and the amount received will be based upon population.

\section{FUNDS FOR AGRICULTURAL EXPERIMENT STATIONS}

(1) The Hatch Act-The first appropriation for agricultural research was approved March 2, 1887. This law, known as the Hatch Act, provides an appropriation of $\$ 15,000$ annually to each state.

(2) The Adams Act-The Adams Act was approved March 16, 1906 and is for the same general purpose as the Hatch Act but emphasizes original researches or experiments. No part of the Adams Act can be used for printing and only five per cent for buildings or purchase of land. It provides an appropriation of $\$ 15,000$ annually.

(3) The Purnell Act-The Purnell Act, approved February 24, 1925 , provides a total of $\$ 60,000$ to each state. This bill emphasizes economic and social research and permits expenditure of ten per cent for buildings and land. It also provides for printing.

(4) The Bankhead-Jones Law-This law provides for a government allotment of $\$ 5,000,000$ for agricultural research, sixty per cent of which is allotted to the state experiment stations; and forty per cent to the Secretary of Agriculture. This bill is allotted to the states in "an amount which bears the same ratio to the total amount to be allotted as the rural population . . . of a state bears to the rural population . . . of all the states."

To receive these funds each state must show an expenditure from state funds of equal amounts for agricultural investigation. These funds are to be used for "research into laws and principles underlying basic problems of agriculture in its broadest aspects."

FUNDS FOR AGRICULTURAL AND HOME ECONOMICS EXTENSION

(1) Smith Lever Law-The first important federal legislation for agricultural extension work was approved May 8th, 1914. This law provided a uniform allotment of $\$ 10,000$ to each state and an ultimate total of $\$ 4,100,000$ to be appropriated to the states "in the proportion which the rural population of each state bears to the total rural population of all the states." The Smith Lever funds must be used for "giving instruction and practical demonstrations in agriculture and home economics to persons not attending or resident in said colleges." It is further required that the state must offset these funds by an equal amount. 
(2) The Capper Ketcham Act-On May 22, 1928 the Capper Ketcham Act was passed to be used for agricultural extension work. The bill requires that at least $80 \%$ of all appropriations under this act totalling $\$ 17,280,000$ shall be utilized for payment of salaries of extension agents in counties and for the first time recognizes the important junior extension work with boys and girls and seems to suggest further development of home demonstration work among women.

(3) The Bankhead-Jones Law-Approved June 29, 1935, Section 21 of the Bankhead-Jones Act of 1935 provides an ultimate final appropriation of $\$ 12,000,000$ annually to be allotted to the several states under the same terms and under the same conditions as the Smith Lever Act of May 8, 1914 except that $\$ 908,000$ which shall be paid to the several states and Hawaii in equal shares and the remainder shall be paid to the states "in the proportion that the farm population of each bears to the total population of the several states." It is also specifically stated that no offset of state money shall be required.

The laws named herewith give recognition to three great educational policies; first, the training of young men and women for the vocations of agriculture and mechanic arts; second, the utilization by these institutions of science as an instrumentality to solve the problems of agriculture; and third, a nation-wide agency to extend the practical values of these researches to farmers and farmers families now on the land.

\section{THE SPIRIT OF THE LAND GRANT COLLEGE}

After more than three-quarters of a century of brilliant achievement we may observe with satisfaction the great contributions of the land grant college to the public welfare. Their insistence upon the value of education in every walk of life, their foundation upon the solid rock of scientific research, their efforts to put knowledge to work, and their conscientious recognition of their public service character are notable among educational institutions. It is well to inquire somewhat into the deeper motives and underlying spirit responsible for their progress. What, after all, is the spirit of the land grant college? The best answer to this question is to be found in the opinions of the great leaders of this movement. At the 45th annual convention of the Association of Land Grant Colleges and Universities in 1931, there were presented four great papers by four of the great leaders in agricultural education. Dr. Eugene Davenport of the College of Agriculture of Illinois in discussing this subject states, "About three quarters of a century ago a new spirit was born into the policy and purpose of education in America. It was the spirit of the land grant college, born of a determination to set knowledge at work for the betterment of that mass of our common citizenry who live by the soil or the shop, and without whose welfare selfgovernment cannot long endure. 
"Today, the college or university which is inspired by the landgrant spirit considers itself not simply or mainly as a teaching organization but as a public service institution, not simply in and for agriculture and engineering but in all the affairs of life.

Speaking in similar vein Dr. W. J. Kerr for many years president of the Oregon Agricultural College emphasizes the educational pioneering of these institutions and their great contribution to Democracy.

He says:

"Pioneering in new fields of effort has made constant demands on the resources of the land grant colleges. In the beginning necessity made them resourceful. Having mastered their initial problems, they gained strength and courage to attack others as they appeared. Servants of the state and nation, in a peculiar sense, they have accepted every public emergency in peace and war, as a challenge to their initiative and resourcefulness.

"In keeping with the spirit of the pioneer, which has characterized the land grant colleges from the beginning, is their spirit of progress, which inspires them to be forever alert to improve existing conditions. Unfettered by tradition, developed for the most part in the freer atmosphere of the West, they have been leaders in the progress of scientific research, in the application of science to agriculture and industry, in the organization and improvement of technical and vocational education.

"Progress today is based on science. The land grant colleges, as centers for the development and dissemination of science, have been inseparably associated with progress in this country throughout the two generations since their establishment. All applied science, as, fostered by these institutions, is designed to promote progress. . . .

"Finally, the spirit of the land grant institutions is the spirit of service. A major function of any college or university is service to its constituents. In the case of the land grant colleges this obligation is toward the entire commonwealth.

"Examples abound throughout the country of whole industries whose existence is directly due to the work of the land grant colleges - . The aggregate contribution to the economic welfare of the country through new and improved production resulting from agricultural research, teaching, and extension, according to recent reports from the land grant institutions, is estimated at more than one billion dollars a year.

"But greatest of all contributions of the land grant institutions has undoubtedly been in the education of youth."

President E. A. Bryan of Washington State College, speaking on the same subject gives expression to the idea that the land grant college represents a revolution in educational philosophy. He says:

"The advent of the system constitutes an epoch in higher education. It was the beginning of a revolution whose full force is not yet spent. It has been a revolution in the means or instruments used 
in higher education; in the methods employed; and in the purposes of those who seek it and in the community that provides it.

"The spirit of the land grant institutions is to be interpreted not only as it is found in those colleges and universities which have accepted and enjoyed the provisions of the great charter, but also in the changes in those institutions upon which a portion of the same spirit has fallen and in its reaction upon secondary and elementary education. The proper interpretation of the spirit will also include its reaction on the social and industrial status of the community and the evolution of industrial democracy as a goal for the race.

"Our late survey truly points out the land grant college as a movement toward democracy. Yet the apparent assumption that this was true because it opened up the way to larger numbers to get a college education or to engage in pursuit and profession not hitherto available, comes far short of including all the democratic implications of this educational movement. It is permeated by the very spirit of freedom which is of the essence of democracy."

And finally President W. O. Thompson for many years president of Ohio State University gives the opinion of a broad minded educator responsible for all types of education in a great university. He says:

"First of all, let me remind you that the land grant colleges did not have the ordinary background such as was common among the colleges of the older type. They were not the setting up on a new soil of the same old type of house in which the fathers had lived for generations. This movement was not an effort to transplant from across the waters the type of institution that had greatly benefited other people.

"Nor was this type of institution born of the existing colleges. . . .

"Thirdly, this was not a popular movement in the sense that it sprang up all over the country like flowers in the springtime. If the country had waited until the colleges had called for such a movement or until there had been a landslide of public sentiment calling for an institution of a new type, the probabilities are that no such an institution would have ever come into existence.

"Fourth, let me now suggest, therefore, that this land grant movement, if we may use that term, was the first great nation-wide movement ever organized in any known government in the interest of higher education which should definitely include the basic interest of the products of the earth, namely, agriculture, mining and other allied resources.

"Fifth, another consideration is that these institutions from the very outset were institutions of a new and, of course, a different type from any existing institutions.

"The Land Grant Act . . . gripped at once the entire nation and set out as one of its specifications the theory of applied science. 
"Perhaps I should say that in addition to the ordinary current idea of education being for life the agricultural college came in with a program of education in life. . .

"I should be disposed . . . to say that the spirit of the land grant colleges was a progressive spirit contented in one particular, namely, to be a college where investigation and research make a distinct contribution to the increase of knowledge-the source materials with which all education must begin." 


\section{PART III.-AMERICAN AGRICUL- TURAL EXPERIMENT STATIONS}

On March 2, 1887, President Grover Cleveland signed the Hatch Act establishing agricultural experiment stations in the United States. The passage of this legislation represented an entirely new governmental policy; it was the recognition of the responsibility of the federal government for the progress and development of the agricultural industry through research. It was also a recognition of the developing importance of science in the national economy. The results of this legislation, after fifty years of experience, have fully justified the faith of the founders in the value of science for solving the problems of the farm, and in the economic and social returns from the activities of these agencies. The discoveries of the agricultural experiment station have had a profound influence upon agriculture as an industry, the economic and social life of farm people, the commerce in agricultural commodities, and upon education itself.

The passage of the Hatch Act, however, was not the beginning of agricultural research. Indeed, agricultural experimentation had been going on for many years in a number of states. The Office of Experiment Stations in 1938 reported that there were fifteen organized experiment stations prior to the passage of the Hatch Act. Some of these were established by the state legislatures, some by the land grant colleges and some even by private initiative. In many states, agricultural investigation was conducted as a function of the land grant college so that twenty-nine states were actually carrying on scientific research for the solution of agricultural problems before March 2, 1887.

While it is true that the first effort of the State Experiment Stations was to solve the immediate and local problems of agriculture in the several states, it was early apparent that many of the problems relating to agriculture were of nation-wide significance and were of equal value to all persons engaged in agriculture. Plant and animal nutrition, diseases of plants and animals, plant and animal breeding, the physiological phenomena associated with animal productionmilk secretion, egg production, wool growing and many others-were of national or even international concern. It was, therefore, natural that a nation wide attempt should be made to correlate and coordinate the work of the several states and the United States Department of Agriculture. The progress in this direction is noteworthy. There are at the present time (1940) more than one thousand three hundred and fifty cooperative projects between the Department of Agriculture and the individual states. In some projects a number of states are involved. It is not too much to claim that this national system of 
scientific research in the interests of agriculture is an educational phenomena without parallel in the history of science.

This important result could not have been secured except for the efficient type of organization characterizing these institutions and the various voluntary organizations involved in this movement. We must, in the first place, give great credit to the wisdom of the original leaders in the United States Department of Agriculture who required a rather definite type of organization for each experiment station, the chief requirement being the appointment of a director. of the agricultural experiment station who should deal directly with the Office of Experiment Stations in all matters of federal concern relating to the expenditure of federal funds. From the very beginning, it was made clear that if the agricultural experiment stations were to have any important influence in the administration of experiment station affairs, it was necessary for them to have an organization in which all states might be represented. There was organized, therefore, the American Association of (1887-1919) Agricultural Colleges and Experiment Stations, since 1919 known as the Association of Land Grant Colleges and Universities. This association. provided for an executive committee which was authorized to deal with the Secretary of Agriculture and with Congress in all matters. of concern to the land grant colleges and universities. There was thus created machinery which made it possible to efficiently accomplish the unification and correlation of the nation wide research conducted by these institutions.

The movement for national cooperation and coordination in agricultural research culminated in the establishment of regional laboratories authorized by the Bankhead-Jones Act of June 29, 1935. These. regional laboratories to be located in the great agricultural regions of the United States are administered by the Secretary of Agriculture in cooperation with the directors of the agricultural experiment stations. of the states concerned.

In the development of the cooperation and correlation of research, I think, we must give due credit to the joint committee on the projects and correlation of research which was organized with a membership of six persons; three representing the United States Department of Agriculture, and three representing the Agricultural Experiment Stations. This committee was organized in 1913 and it has for more than a quarter of a century encouraged cooperation, recommended procedures, and, in common with the other agencies here described, has made a substantial contribution to the coordination and correlation of agricultural research in the United States. By these agencies, there has been substantial elimination of duplication by the several states and the Department of Agriculture in the conduct of agricultural research. The machinery provided should prevent such duplication in the future and as a result, it can be confidently asserted that the federal and state appropriations for agricultural research. 
are being wisely expended and in such manner as to accomplish the most effective solutions of farm problems.

Commenting upon the cooperative plan of research between the federal government and the state agricultural experiment stations, the science committee of the National Resources Committee (1938) has made the following statement: "Through this practice, a system of cooperative agreements between the various research bureaus of the Department and the several Experiment Stations has grown up which has proved one of the most effective devices for correlation in the whole field of governmental research."

The general demand for the establishment of agricultural experiment stations created to solve the farmers' problems by scientific research was a logical outgrowth of the Morrill Act of 1862 establishing agricultural colleges. These colleges were required by federal law to teach "agriculture and mechanic arts." They were also required to teach other correlated subjects with particular reference to their application to agriculture and mechanic arts. They very early discovered that this requirement involved a new approach and new subject matter. There existed no organized body of knowledge in 1862 which could be called agriculture or mechanic arts. They could not efficiently teach such a new subject until a body of knowledge had been assembled. In attempting to assemble this knowledge they discovered that after all very little effort had been made to solve the many difficult and intricate problems confronting the farmer. It was therefore, the demand of agricultural teachers themselves which started the agitation for agricultural experiment stations. The demand of farmers was responsible for the interest of agricultural teachers. The farmer assumed that the colleges of agriculture could solve his problems. He very early discovered that many of the questions propounded by him could not be answered. It was these unanswered questions, therefore, coming to the teachers of agriculture that finally resulted in a demand upon the federal Congress for a scientific agency to be established at each college of agriculture, primarily to answer these questions asked by farmers.

In all the agitation for experiment stations there was emphasized service to agriculture and farmers. A number of informal conferences in several regions of the United States lead finally to a general demand for national conferences. One of the first of these was held in Chicago in August, 1871. In February, 1872, the United States Commissioner of Agriculture called a conference of delegates from the several states to meet at Washington. In addition to these more or less official conferences, there were two organizations formed which had a substantial part in furthering the legislation for agricultural experiment stations. These were an Association of Agricultural Teachers and the Society for the Promotion of Agricultural Science. These two groups had an important influence in educating 
the public mind to believe in the importance and value of agricultural research. Many informal conferences and papers in agricultural periodicals stressed the importance of experimentation in agriculture. A convention of agriculturists met in Washington on the call of Commissioner of Agriculture Loring in January, 1882. A similar convention met in Washington in January, 1883. In each of these conventions a principal subject of discussion was the need of agricultural experiment stations. As a result of these numerous conferences and the general interest, there was prepared legislation providing for the establishment of experiment stations closely associated with the colleges of agriculture in the several states. One of the first bills introduced in Congress was by C. C. Carpenter of Iowa on May 8, 1882. This same bill was later fathered by A. J. Holmes also of Iowa who replaced Carpenter in Congress. The so-called Holmes Bill gave large administrative control to the United States Department of Agriculture. This feature of the Bill was not regarded as satisfactory by the representatives of the land grant colleges. The Bill, however, was strongly supported by a group of college presidents before the Congress of 1884 and 1885, but failed of final passage.

Failure on the part of Congress, however, to approve of this legislation did not in any manner diminish the enthusiasm of its supporters or discourage their efforts. During these years of agitation for agricultural experiment stations, the demands from farmers, agricultural officials and teachers in agricultural colleges grew rapidly and gradually paved the way for the final approval of this legislation. With the election of Grover Cleveland and his inauguration on March 4th, 1885, a change in sentiment towards this legislation was apparent. In the beginning of Cleveland's administration, the honorable Norman J. Coleman of Missouri was appointed Commissioner of Agriculture. He had been for many years an active friend of agricultural legislation and a national leader in agricultural affairs. He welcomed this opportunity to support what he regarded as a very advanced step in national policy affecting the agricultural industry. Two other men of great influence in Congress had a large part in the final approval of this legislation. The Honorable William H. Hatch of Missouri, Chairman of the House Committee on Agriculture, one of the ablest parliamentarians in Congress at that time, and a forceful leader in all agricultural legislation became the principal advocate and determined supporter of the Agricultural Experiment Station Bill. So important was his influence and so generally was it recognized that the bill finally passed has ever since been known as the Hatch Act. Another member of Congress, having an important part in securing this legislation, was the Honorable James Z. George of Mississippi, a member of the Committee of Agriculture and Forestry of the Senate. The names of these two men will be remembered with gratitude by the farmers of the nation who have so greatly benefited by the beneficent results from the passage of this act. 
In July, 1885, there was held in Washington a convention of agricultural leaders called by Commissioner Coleman. The principal subject of discussion at this conference was the legislation then pending in Congress for the establishment of Agricultural Experiment Stations. Commissioner Coleman's letter calling this convention stated its purpose to consider "the question of Experiment Stations and the relation they should hold to this department, the best means of bringing about Congressional action, and of harmonizing the interests of the different state institutions and the national department." There were represented at this conference twenty-eight states and three territories. The persons attending this convention represented the most advanced leadership in agricultural education in the United States. It also included leading agricultural officials, many representing boards of agriculture. At this convention there was a definite and organized effort to secure the passage of this Experiment Station Bill by Congress. Upon the authority of this conference, there was appointed a committee "to cooperate with the Commissioner of Agriculture" in the endeavor to secure such legislation. This committee was composed of Messis. Atherton of Pennsylvania, Willits of Michigan and Lee of Mississippi. As a result of the deliberations of the conference of July, 1885, and frequent conferences by this committee with Congressman Hatch and Senator George a bill was finally introduced in the Senate by Mr. George and a similar bill in the House by a Mr. Hatch. The Hatch Bill in the House received approval by the Committee essentially in the form introduced. The companion bill introduced by Senator George in the Senate was substantially amended. The most important amendment perhaps was the elimination of the words "the Department of Agriculture" and the substitution of a clause placing the stations "under the direction of the college or colleges or agricultural departments of colleges". The original Experiment Station Bill was to develop these institutions as administrative units of the United States Department of Agriculture. This administrative plan was disapproved by the leaders of agricultural education who insisted that the scientific work of these institutions must be independent and free from federal control. This latter principle prevailed and we find, therefore, the Experiment Station system of the United States developed independently of federal control. Local initiative has thus been encouraged. Emphasis upon local problems has been possible, and as a result there has been universal support by the people in the individual states. It is significant in this connection to note that the states have from the beginning provided larger amounts for the agricultural experiment stations than has been provided by Congress. This undoubtedly is due to the prompt response of the state experiment station to the demand for the solution of regional and local problems primarily important to the individual state. 
The George Bill was eventually passed by the Senate in its greatly amended form. This amended bill was considered by the House Committee on Agriculture and on the recommendation by Mr. Hatch adopted by them as a substitute for the Hatch Bill. In this form it passed the House. It was approved by President Cleveland on March 6 th, 1887, and thus became the law of the land. Dr. E. W. Allen, formerly Director of the Office of the Experiment Station, commenting on the new policy thus inaugurated by Congress stated, "This nation wide subsidizing of research in agriculture was evidence of a change which had come in the conception of the relationship of the federal government and the states. It was a recognition of a joint responsibility in developing the industry of agriculture on a high stage of efficiency and it was a new expression of what the general government may do under the constitution for the promotion of the public welfare."

Dr. Arthur J. Klein in the Survey of Land Grant Colleges and Universities reported in Bulletin No. 9, Volume 1 of the U. S. Office of Education has called the result of the passage of the Hatch Act "the greatest national system of Agricultural Experiment Stations in the history of the world."

If the policy of federal control as first proposed in the legislation for the establishment of Agricultural Experiment Stations in the states had prevailed, the whole course of their progress might have been changed. Federal control means regimentation, standardization, and discouragement of local initiative. It means emphasis upon national as distinguished from local problems. Whereas local control emphasizes the importance of the problems of the individual farmer, federal control will always regard the national purpose as of chief importance. It is difficult to see how one man or group of men in Washington can plan the agriculture of forty-eight different states. The wisdom of placing the administration of these institutions in the colleges of agriculture has been fully justified. These agencies have accomplished the purposes of their founders to an unusual degree. Their success has been little short of phenomenal.

The final passage of the Hatch Act was a recognition of a national faith in science as an instrumentality for solving the practical problems and difficulties confronting the farmer. It is to be noted that the successful development and progress of the Agricultural Experiment Station has been coextensive with the progress and development of science itself. Scientific discovery lies at the very basis of all modern economic and industrial development. The contributions of scientific research to this development is difficult to measure but none the less profoundly significant. Agricultural research has been no less important in its influence upon the economic and social progress of farm people than has similar research in connection with the remarkable developments of modern industry. 
It must be admitted that in the beginning much of the work of the agricultural experiment stations was of a superficial character. The exact methods of science, now a part of the equipment of every recognized scientist, was not then so generally available. The farmer demanded quick solutions and for many of his problems only long painstaking research could accomplish these solutions.

An examination of the early publications of the experiment stations indicates that the principal interest of farmers was in varieties or breeds. So the stations attempted to answer these questions. What is the best variety of wheat? What variety of corn will make the largest yield? What breed of live stock is most profitable? Along with these questions the farmer wanted to know how to prevent animal diseases and to limit losses from insect and fungus diseases of plants. There was very great interest in the developing science of entomology and great progress was made in the study of insects and treatment for insect diseases. There is also evidence in much of the early work that rations for feeding livestock was a matter of great concern to live stock, dairy, and poultry farmers. All of these problems were vigorously attacked by the early experiment stations. There was little attempt in the beginning to establish principles and broad generalizations upon which could be builded the science of agriculture, but gradually it was discovered that if real progress was to be made, there must be undertaken some of the most fundamental and basic studies relating to the chemistry of agricultural products, the biology and physiology of plants and animals and the geology of the earth's surface, particularly as related to the origin, distribution, and formation of soils.

In the beginning the farm people for whom these stations were primarily founded were skeptical of the findings of scientific men. The farmer's knowledge of his enterprise was traditional. Through long generations of hard-earned practical experience, the farmer had developed a knowledge of procedure. He had come to believe that only the knowledge gained in such manner could be reliable. But with the increased efficiency of scientific research and the improvement in the methods of science the farmer found his most difficult problems being solved. The researchers themselves became more conservative in announcing wide application of scientific results. The farmer discovered that after all the results of science were practical and not theoretical as he had insisted.

In the beginning agricultural investigators were influenced quite generally by the prevailing insistence by scientific men that it was no function of the investigator to interest himself in the applications of the results of his researches. It was sufficient that he establish the truth; "let the farmer make his own application". But gradually there developed a feeling among experiment station workers that their duty to the farmer did not end with establishing truth but in developing a technique for the use of the knowledge so discovered. 
We must, I think, give great credit to the agricultural experiment stations not only for developing institutions of high scientific merit but for developing a technique for the use of their knowledge which is notable among scientific agencies.

So far as the writer knows, no other group of scientists outside of the industrial research laboratories have so keen an appreciation of the probable use to be made of their findings as the workers in agricultural experiment stations. This development is undoubtedly an outgrowth of the policy of the experiment stations themselves. These institutions have looked upon science as a means, as a tool, to solve the many intricate problems of agriculture. They start with a problem and bring to bear upon this problem all the instrumentalities which we call science. It cannot be claimed for experiment station workers that they have no interest in the use to be made of the results secured. They have a vital interest and because they have a vital interest in the use of the knowledge gained, they have perhaps unconsciously but nevertheless effectively contributed to the development of a technique for the use of knowledge which is outstanding among scientific institutions. This attitude of experiment station workers is undoubtedly one of the principal reasons why the agricultural experiment stations have received almost universal approval and support from not only farmers for whom they were primarily established but chambers of commerce, bankers, and firms and corporations engaged in the handling of agricultural commodities. As a result of the general approval of all these agencies, the continued and substantial support of the federal and state governments has been assured.

It may well be that the example of the agricultural experiment stations through a fruitful period of fifty years, is in part, perhaps in large part, responsible for the evident growing attitude of men of science to have greater regard for the utilization of the results of their researches. It is certainly the purpose of all scientific research to bring happiness and not a curse to mankind. Albert Einstein addressing the student body of the California Institute of Technology gives expression to this thought in the following language, "Concern for man himself and his fate must always form the chief interest of all technical endeavors . . . in order that the creations of our mind shall be a pleasure and not a curse to mankind."

I think that it is a true observation that the agricultural experiment stations have ever kept clearly in their minds the well being of rural people. They have recognized the fact that scientific discoveries may be destructive as well as constructive. It is to the everlasting credit of the agricultural experiment stations that their work is constructive and it is constructive because the investigator is motivated by a deep interest in man himself and the use of knowledge created for his benefit. 
In the minds of many scientists there has been a lack of appreciation on the part of the public generally of the real value of science. The publication of "Science News Letter" is one well-known means fostered by scientists to popularize science. It is interesting to note that no such systematic effort has been necessary to popularize the work of Agricultural Experiment Stations. This fact is the more significant when we remember that of all groups in our modern life, the farmer is most wedded to tradition. He is most critical, and perhaps the last of all industrial workers to apply new and improved methods. One of the outstanding achievements of the Agricultural Experiment Stations has been to accomplish a revolution in the thinking of farm people, and by so doing to develop an appreciation of exact science based upon experimentation. This accomplishment with the most conservative group in our social system is notable.

It has been pointed out that the establishment of the Agricultural Experiment Station by the Hatch Law in Congress was the beginning of a new era in agricultural education. It was the beginning of a complete change of attitude on the part of farmers and all others interested in agricultural betterment toward the colleges of agriculture. So successful were these divisions of the colleges that Congress and the several states looked with favor upon their activities and made larger and larger appropriations for their support and maintenance.

From the latest available report of the Office of Experiment Stations published in April 1939, these agencies extended $\$ 19,848,068.43$ for agricultural research. Of this amount there was received by the State Experiment Stations from the federal government under the provisions of the Hatch, Adams, Purnell, and Bankhead-Jones laws respectively a total of $\$ 6,232.500$. The states contributed for the same purposes $\$ 13,615,568.43$. The states thus contributed more than twice as much for scientific research in the interests of agriculture as was received from the federal government. It was confidently asserted by the authors of the Hatch and subsequent federal laws for experiment station work that the appropriations by Congress would stimulate state enterprise and result in large state grants for similar purposes. This prophecy has come true. The states are thoroughly committed to the policy of legislative support for agricultural research. It is interesting to note, moreover, that this contribution of the states is not based upon offset provisions since no experiment station law excepting the latest Bankhead-Jones statute requires that any portion of the federal appropriations shall be offset by the states.

There are now (1940) reported more than 4,000 scientists engaged in agricultural research in the experiment stations of the United States. Not all of these devote their entire time to research. These investigators represent practically every major and minor division 
of modern science. The titles borne by these workers are not always an indication of the particular branch of science, they represent, but rather the type of problems they are employed to investigate. Thus a physiological chemist may be a professor of dairy or animal husbandry; a plant physiologist, a professor of horticulture; a geneticist, a professor of field crops or animal husbandry; or a colloid chemist, a professor of soils. This is but another evidence that these stations continue to look upon science as a means and not an end. Science is a tool to be used in solving the problems of agriculture. The problems of agriculture originate chiefly in connection with soils, crops, animal and diary husbandry, horticulture, etc. It is logical that the scientists should be located where the problem lies. It is in these so-called practical departments that the investigator finds the most complete equipment and resources in land, livestock, machinery, buildings and laboratories. It is also true that these departments have developed a true perspective and knowledge of agricultural problems. They are in a position to decide which are the most worthwhile problems and by reason of this knowledge to avoid dissipating research funds on investigations which may be of interest to the scientist but have little agricultural importance.

That the expenditure of large sums for scientific research have been productive is indicated by the number of publications reported from the several stations. During the period (one year) covered by this report there were issued 571 bulletins on completed work in the Experiment Stations. These 571 bulletins included 4,221 pages. To supply the demand for these publications, mostly from farmers, required the issuance of 686,547 copies.

These simple statistics give some little conception of the vast reach of these institutions of science organized for the solution of farm problems. They do not, of course, give us any information as to the quality or usefulness of the research undertaken, but the great popularity of these institutions, the almost universal approval and support of their policies and programs of work is significant. These intangibles cannot be measured by statistical reports, but they are of fundamental importance. 


\section{THE ADMINISTRATION OF EXPERIMENT STATION FUNDS}

The expenditure of funds appropriated by Congress for any purpose involves more or less federal control. The extent of the federal influence in the administration of these funds is a matter of great importance. It becomes increasingly important as larger and larger appropriations are made for activities by federal agents within the state. There are still vigorous advocates of the old principle of states' rights. There are those still who insist that any federal funds allocated to the States should be administered by state officials, that a central office located in Washington is not and can not be the most efficient agency to determine policies within the States. The proponents of this policy insist that the very different conditions prevailing in 48 different states require local rather than national administration.

This controversial question has not been absent in the history of the progress and development of agricultural experiment stations. On the one hand great fear has been expressed that federal control involves federal domination and, in general, results in discouraging local initiative, particularly in all matters pertaining to education, including research. On the other hand a greater degree of federal control is advocated by many in order that a better coordination and correlation of the results of scientific research may be accomplished. Federal control discourages duplication and emphasizes the national importance of certain researches.

The provisions of the four laws appropriating federal funds for agricultural research include provisions which involve a certain administrative relation of the federal government to these institutions. In the beginning the proposal was made that each of the agricultural experiment stations should be a definite organized part of the Federal Department of Agriculture. This proposal was unacceptable to the several States and was, as we have seen, eliminated from the original Hatch Act. The administration of the experiment stations was placed definitely "under the direction of the college or colleges or agricultural departments . . . in each State". But the Hatch Act did provide that the Secretary of Agriculture should attempt to tabulate the results of investigation, to indicate lines of inquiry, and to examine annually the records of expenditure by the States to determine if the funds had been expended according to law. Similar provisions were included in the Adams and Purnell Acts. The provision of the Bankhead-Jones Act as related to the duties and powers of the Secretary of Agriculture in the administration of these funds has not yet (1940) been clearly established, but, so far, the Office of Experiment Stations representing the Department of Agriculture in the administration of Experiment Station funds has followed essentially the same administrative procedures as have been followed so successfully in connection with the Hatch, Adams, and Purnell Acts. 
It must be admitted, I think, that the administrative relation of the Secretary of Agriculture to the research funds appropriated by Congress has been exercised with discretion. No attempt has been made to dominate or control the work of agricultural experiment stations. The minimum amount of administrative supervision has been the rule. As a result of this policy, local initiative has been encouraged. Proper emphasis has been placed on the solution of local and regional problems. The state institutions have been able to harmonize the use of federal funds with state laws and institutional requirements. After fifty years of experiment with this type of successful and satisfactory federal administration, the state administrators of agricultural experiment stations have expressed general satisfaction with the results.

The progress, development and conservation of our agricultural resources is a matter of national concern. There is, therefore, a growing tendency on the part of the federal government to concern itself actively with agriculture and agricultural development. In a sense, agriculture is becoming nationalized and insofar as the nationalization of agriculture has been accomplished it impinges to some extent upon the established policies of states' rights, particularly as these are related to the land grant colleges and universities. There is evidence of a new philosophy of agriculture as a national enterprise.

It is obvious that agriculture is profoundly influenced by national policies. The problem of the distribution of agricultural commodities involves transportation, commerce and industry in general. The policies of other nations profoundly affect agriculture in the United States. Changes in the monetary standard by this and foreign countries influences agricultural prosperity. These problems do not admit of solution by the states. They are national in character and must be federally administered.

Some of the new national projects for the conservation and the development of our agricultural resources which involve federal administration within the states have raised the important question of the relation of these projects to the land grant colleges and universities. Many of these new projects involve research and education through extension methods which parallel, if they do not directly duplicate, similar agencies now fully organized and efficiently administered by the state institutions. It is the opinion of many in the states that all activities of this character involving research and education should be directed by the state agencies. The problem is still unsolved.

The suggestion has been made that the land grant colleges and universities themselves are national institutions and still further nationalization of these institutions might be a solution of this problem. This solution, however, would not be acceptable to the states and would not, in the opinion of most authorities, be regarded as a wise solution. At the moment sincere efforts are being made both by the federal authorities and those responsible for state administration 
to harmonize the differences and certain conflicting opinions to the end that there may be prevented duplication of effort and confusion on the part of the rural people who are the immediate beneficiaries of these helpful services.

It cannot be said that the relations of the United States Department of Agriculture and the state colleges of agriculture are perfectly harmonious or entirely satisfactory to the states, but if there exists dissatisfaction, it is to be found in connection with the new (1933 to 1940) national movements relating to agricultural adjustment, and not to the direct appropriations to the states for teaching, research and extension.

The difficulties have arisen in connection with farm security, soil conservation, flood control, land use planning, and similar purposes for which specific appropriations have been made and specific administrative authority given to the Secretary of Agriculture. There yet remains to be developed a formula which is satisfactory both to the States and the Secretary of Agriculture for cooperative relations in connection with these important national, agricultural developments of recent years. It may well be that the result of 50 years of experience with the administration of experiment station funds by the Federal Department of Agriculture could be adopted as a model in the administration of the new agricultural projects. This experience could at least form a basis upon which to build a permanent federal state relation satisfactory to all concerned.

\section{THE ORGANIZATION OF THE AGRICULTURAL EXPERIMENT STATION}

The college of agriculture has legally three major functions; teaching, research, and extension. In the beginning of these institutions, the teaching function was the only one required by law. When the agricultural experiment stations were established, it was provided that the Secretary of Agriculture should exercise a moderate supervision over their work and expenditures. To fulfill his proper official duty, he later organized the office of experiment stations in the United States Department of Agriculture. This office early encouraged the policy of appointing a director of experiment stations in each state with whom the Secretary of Agriculture could deal in the organization and administration of the station. This was a wise policy.

There were two opinions as to the proper organization of these institutions. There were some administrators who believed that the experiment station should become a division of the college with its own equipment and its own personnel. It should be autonomous and independent of the teaching function. It was argued that teachers burdened with student instruction would neglect their research. After all, teaching ability and research ability are different. A good teacher is not necessarily a good investigator and finally the experi- 
ment station was established to investigate farm problems and serve agriculture, and not to provide facts for teaching students in a college. This point of view seemed to be favored by the office of experiment stations.

Another larger group maintained that good teaching could not be separated from research, that a limited amount of advanced teaching was distinctly helpful to the researcher. There was no fundamental reason why experiment station results, obtained primarily for farmers, should not be fully utilized for teaching students who were to become farmers. Who, after all, knew so well the problems of the farmer and what investigations were urgently needed as did the able teacher of agriculture. With increasing specialization the individual member of the faculty had not only a more exact knowledge of his field but probably more time for research. It must be remembered too that the resources of the experiment stations in the beginning were very limited and could not possibly provide for much of an institution. There were also the demands of live stock farmers, horticulturists, dairy farmers, grain farmers and others for research in their respective fields and these could not be satisfied with the limited staff possible with experiment station funds alone. The necessary apparatus and facilities were, in the beginning, the property of the college. It seemed reasonable, therefore, that while the experiment station should be organized as a division of the college, the station could be most useful and accomplish most by utilizing existing facilities and personnel. This policy has been generally (1940) followed in most states and it has proven very successful. It is, of course, not possible to prove that the functions of the agricultural experiment station will be best served by a close union with the college teaching division. It is certainly true that the college teacher is a more efficient teacher if he is at the same time conducting investigations.

President A. C. Williard of the University of Illinois, speaking at the seventy-fifth anniversary of the founding of Kansas State Colleges of Agriculture and Applied Science, in May 1938 said, "It is becoming more and more difficult to draw the line, if there is a line, between the teaching and research functions of our institutions. Both are essential to education for the industrial classes as conceived by the framers of the Morrill Act."

There is another function performed by this close union of college teaching and agricultural research. This is the training of both teachers and investigators to carry on the work of the colleges of agriculture. The training of personnel for agricultural experiment stations is today a most important function of the college teaching division. The training of agricultural investigators is most competently accomplished where the resources and facilities of the experiment station are closely related to the resources and facilities of the college. 
It is the opinion of the writer that it is the function of the agricultural experiment stations to solve the problems arising in the broad field of agriculture. The first step in accomplishing this service is to know what these problems are. The agricultural departments of the colleges are in a position to know accurately what agricultural problems exist and to determine the relative importance of each. It is true that often a solution of these problems leads to the most advanced studies in science and the investigations most likely to accomplish permanent solutions are those which are founded and buttressed upon the most fundamental and advanced research in the physical and biological fields. Thus we find in the agricultural experiment stations of the present day (1940) that some of the most fundamental and advanced research is yielding most practical returns. The improvement of economic plants becomes a study in genetics. The successful solution of the physiological phenomena of animal breeding becomes research in genetics and the physiology of reproduction. A knowledge of the functions of the pituitary gland and hormones is required in the physiological investigation of milk secretion. Animal nutrition is not a matter of feeding balanced rations only but it involves advanced and intricate knowledge of physiological chemistry.

A discussion of the relation of college teaching and research would not be complete without a consideration of the relation of agricultural research in the colleges of agriculture to the graduate school. In all institutions of higher learning it is the graduate schools that are consciously concerned with the advancement of knowledge. It is these divisions of the universities and colleges which are creative. They are the source of new knowledge. They encourage and foster the highest intellectual attainments. They are our chief training schools for scholars. They encourage original research and independent thinking. It is in these divisions everywhere that we find the highest expression of our intellectual efforts. The most renowned scholars of our time are associated with the graduate schools. In them the scientific method has reached a high degree of development.

It is for these reasons that the colleges of agriculture through their agricultural experiment stations have from the beginning recognized the importance of maintaining a close association with the graduate school. This close association is to be observed first in the function of the graduate school in the training of researchers. The graduate school has trained nearly all the personnel now engaged in agricultural research. The completeness of their training is reflected in the quality of their research. The graduate school has greatly encouraged and developed the scientific method in all advanced teaching. This is an important contribution to the advancement of learning. It is the method universally employed in the experiment stations.

The agricultural experiment stations have developed through the years a large number of eminent scholars in their respective fields. 
These scholars are experienced men of science. They have had the advantage of exceptional facilities in laboratory equipment, apparatus, lands, plantings, animals, adequate buildings, and funds for work. The staffs of the experiment stations therefore constitute a very valuable associated group in the graduate school.

It cannot be denied that the real purpose of the graduate school is the increase of knowledge. The advancement of knowledge, all knowledge, is its objective. This is the purpose of the agricultural experiment station. Their search for solutions of the problems of agriculture has led to the utilization of the sciences. Their present programs involve fundamental research in the physical, biological and social sciences. They are thus in an especially favorable situation to cooperate with the graduate school. This cooperation will be mutually advantageous to both and should be encouraged.

But there is another way in which the experiment stations have added prestige to the graduate school and more completely justified their existence in the minds of the public generally. The problems selected as subjects for theses by students from the college of agriculture are such as to commend themselves to an intelligent public. The researchers are concerned with problems which are generally crying for solution. The particular problems selected by students from the college of agriculture are not chosen merely to satisfy the curiosity of the investigator. They are vital and usually planned with some real appreciation of their application.

The graduate students from the college of agriculture have the very real advantage of working under experienced investigators with the best of equipment and funds when necessary. There is, therefore, to be observed a very close association of the agricultural experiment stations and the graduate schools. This relation should be further encouraged. The stations are fortunate in being able to bring much to the graduate school. The graduate school can become valuable to the experiment stations by insistence on high standards, appropriate supervision and in selection of major subjects of research. 


\section{THE ORGANIZATION OF RESEARCH}

The state agricultural experiment stations of the United States probably constitute one of the best examples of efficient organization of scientific research to be found in this country. This organization of research has resulted in holding these institutions to their purposes-to insure the employment of the best attainable skill, to supply the most essential apparatus, to equip modern laboratories, and in general to provide exceptional facilities in land, domestic animals, orchards, field and garden crops-all of the highest value for efficient research. No one of these nor all of these can insure high scientific attainment but in the hands of wise leadership they become invaluable instrumentalities for the advancement of science. Each station has a director who knows or should know the important problems of agriculture and have personal knowledge and experience in research.

Each station has a staff of specialists, trained and experienced in scientific research. These specialists are at all times available for consultation. The director and his staff have the responsibility of making certain that all the facilities of the station shall be utilized to the fullest extent in solving worthwhile problems. It is sometimes difficult to maintain this attitude in all members of the staff. The often repeated but now somewhat obsolete slogan of "science for science's sake" has no standing in the agricultural experiment station. Too often scientific research is undertaken merely to satisfy the curiosity of the investigator. He wants to know what happens under certain conditions. This attitude is, of course, the impelling motive in good research men everywhere and certainly is to be encouraged so long as this desire to know is applied to important and worthwhile projects. It cannot be too often emphasized or too clearly stated that these institutions are agricultural experiment stations. They are founded by federal and state law to utilize the methods of science in the solution of farm problems. These laws are specific on this point. Public sentiment is likewise primarily concerned with their services to agriculture. Contributions to knowledge in general and to the advancement of science as such are incidental to the main purpose which is to serve agriculture.

As already pointed out, these institutions owe their present importance and real value to the agricultural motive. It cannot be said that the Congress and the state legislatures had in mind the advancement of science as such in appropriating large sums of money to the agricultural experiment stations. Nevertheless, these agencies have made great contributions to science. They have extended our intellectual horizons. They have aided science immeasurably by developing in the minds of the public generally, and in consequence their representatives in government, an appreciation and confidence in science as an instrumentality for solving the real life problems of humanity. 
The form of organization and the methods of administration have been important factors in the widespread acceptance and approval of these institutions. In modern times science advances most and best when organized. The scientific recluse working secretly in his attic laboratory is no longer typical of the modern investigator. We need only compare the faltering progress of science for a thousand years under a system of individual effort with organized research during a mere matter of two decades to realize that organization of research is itself a scientific method of major importance. In 1929, President Hoover speaking before the Dearborn Conference remarked, "It is organized research that gives daily improvement in machines and processes, in methods of agriculture and in the protection of health."

What, after all, are the problems of agriculture? Who is to answer this question? Is the director or the scientist or the farmer or the government itself to decide which are the really worthwhile problems to be solved? Clearly each of these classes of individuals or officials must have a part in answering this question. The director must exercise his broader vision of the needs of agriculture on the advice and council of his staff. The scientist alone will be the best authority under some circumstances. But the farmer certainly cannot be ignored. After all, the problems are his concern. He is most affected. The problem is often determined by his own need. Its solution is the function of the investigator. Cooperation of all these will insure a safe answer and a wise program of research by the station.

The idea, that the stations are impelled, by pressure of farm need, to conduct superficial research no longer holds. The farmer himself has developed an exceptional knowledge and appreciation of the scientific method. He, no less than the administrators themselves, is primarily interested in good research. He is not pressing for inadequate solutions no matter how quickly obtained. In the present organization of the experiment stations fundamental research is the rule rather than the exception. 


\section{EFFECTIVE PUBLICATION OF EXPERIMENT STATION WORK}

The experiment stations have provided a literature of agriculture. It may almost be said that the publications of the experiment stations constitute the literature of agriculture. All agricultural writing is related more or less directly to their findings. These reports cover the entire field of agriculture. They likewise comprehend almost every important branch of natural and social science. These bulletins based as they are upon painstaking scientific research constitute a reliable guide to practice. Their usefulness is generally recognized. All agricultural teaching of whatever grade is based on the scientific research of Experiment Stations. Teachers of agriculture now instruct with confidence because all subjects now represent organized and systematized knowledge solidly based on results of scientific experimentation. Probably no other curriculum is so generally builded around and on science as the agricultural curriculum.

All this resulted in a revolution in the farmer's attitude toward these institutions. The farmer has changed from an attitude of extreme skepticism to one of great confidence. The stations and their close allies, the extension services, must be given full credit for this revolution. Honest work uninfluenced by passing fads and a determination to discover truth has been responsible for this result. This faith and confidence of the farmer in the honesty and ability of the station to serve him in his difficulties is extremely gratifying, but, in some instances, has come to be something of an embarrassment to the stations. After all the experiment station is not entirely infallible, neither has it solved all the farmer's difficulties. There are still vast unexplored fields for scientific endeavor.

The available evidence is eloquent testimony to the fact that the experiment station worker has been amazingly industrious. The published results of completed research by no means cover all the work of these investigators. The vaults of these stations are filled with a vast accumulation of data which should be organized and made useful. There is great need today for agricultural philosophers, men like Darwin who can assemble the facts of science and from these establish universal laws. The interpretation of the results of research is a matter of greatest importance and is too often neglected by the investigator. He is too often merely an observer of phenomena and too seldom an interpreter of the real meaning of his own researches.

Dr. John C. Merriam, president emeritus of the Carnegie Institution, has compared the use of technical language in reporting scientific results to the confusion of tongues among the builders of the Tower of Babel. The scientists of one group often do not understand what another group has accomplished merely because the technical language used in reporting results is unintelligible to the other 
scientists. He relates that some years ago the Carnegie Institution decided upon a plan of releases undertaken primarily to acquaint the man in the street with the discoveries of science. Their most important reaction came not from the man in the street but from men in other scientific fields who said, "Now for the first time we know what those people over there are doing."

The importance of the effective publication of experiment station work is not fully recognized by the workers themselves. It is one thing to discover new truth; it is another to present the truth in such manner that the discoveries will have the widest possible use. Dr. A. A. Michelson is quoted as saying, "There are not many in science who accept it, but I believe that the more artistic the statement of a paper in science, the larger the chance of presenting the truth." Regardless, therefore, of its possible use, the earnest desire of every scientist is to present his work in an effective manner. It is clearly important that the discoveries of science should be widely disseminated. It would seem to be self evident that the use of a terminology or form of expression which cannot be understood by scientists in other and even related fields is exceedingly unwise.

The authors of experiment station bulletins have been criticized by farmers and by newspaper writers on the grounds that they report their results in the language of science, and that they are generally too conservative in suggesting applications. Scientists on the other hand have sometimes criticized the reports of agricultural investigations for the reason that there is an evident attempt in the publication to popularize the subject matter of the bulletin. In general, there is evidence to show that the reporting of results by experiment station workers has been effective writing particularly from the standpoint of the purposes of such researches. The attempt at clarity and simplicity in the presentation of even the records of scientific work is to be commended. There is no fundamental reason why a scientist should report his work in a language unknown to an intelligent reader. The importance of presenting scientific discovery with simplicity was emphasized by Lord Kelvin. He is reported to have remarked: "That physicist, who, having completed a research no matter how attenuated, on reaching the street can not explain his finding and its usefulness to the first man he meets, should return to his laboratory; his research is not complete." In the writer's opinion, one reason for the popularity of the scientific work accomplished by agricultural experiment stations lies in the fact that these investigators have made more available to the intelligent public the results of their work.

However, there is still room for improvement. Some investigators still feel that the technical language used bears some relation to the quality of the work done. Some investigators take pride in a nomenclature known only to a comparatively small group of scientists. In the interests of science itself there should be an effort to report results 
with such clarity and such simplicity that the intelligent reader may be able to secure from his reading a fairly definite idea at least of what the investigator has really discovered.

Too often the experiment station worker in reporting results devotes far more time to a discussion of how his results were obtained than to stating as clearly as possible just what has been discovered. After all, the vital thing in any investigation is the discovery made. The workers in agricultural experiment stations owe much to the agricultural papers and to the rural newspaper for the intelligent presentation of the results of agricultural research. These agencies have been exceedingly helpful in disseminating the work of the stations.

\section{THE LEGAL PURPOSE OF EXPERIMENT STATION FUNDS}

The laws appropriating funds for agricultural experiment station work have greatly influenced the direction and trends of such experimentation. The purposes for which the federal funds could be used were rather definitely stated in the several acts. The purposes for which the funds may be used are different in each of these acts, but are obviously intended to adequately cover the field of agriculture.

\section{HATCH ACT (APPROVED MARCH 2, 1887)}

The provisions of the Hatch Act were, "That it shall be the object and duty of said experiment stations to conduct original researches or verify experiments on the physiology of plants and animals; the diseases to which they are severally subject, with the remedies for the same; the chemical composition of useful plants at their different stages of growth; the comparative advantages of rotative cropping as pursued under the varying series of crops; the capacity of new plants or trees for acclimation; the analysis of soils and water; the chemical composition of manures, natural or artificial, with experiments designed to test the comparative effects on crops of different kinds; the adaptation and value of grasses and forage plants; the composition and digestibility of the different kinds of food for domestic animals; the scientific and economic questions involved in the production of butter and cheese; and such other researches or experiments bearing directly on the agricultural industry of the United States as may in each case be deemed advisable, having due regard to the varying conditions and needs of the respective States and Territories." It is clear from this requirement in the basic experiment station law that it was the intention of Congress to provide scientific research facilities for making experiments relating to the then most important agricultural enterprises. It was clearly left to the administrators in charge to determine "in each case" what particular researches or experiments were essential. 


\section{Adams Act (Approved March 16, 1906)}

In formulating the provisions of the Adams Act, it is clear that Congress intended that the sums appropriated should be used for similar purposes to the funds appropriated under the Hatch Act. It was, however, specifically stated that the funds provided under the Adams Act were "to be applied only to paying the necessary expenses of conducting original researches or experiments bearing directly on the agricultural industry of the United States, having due regard to the varying conditions and needs of the respective States or Territories."

Both the Hatch Act and the Adams Act apparently had in mind researches relating to the solution of problems concerned with production. There is no clear warrant in these two acts for economic or social research. Attempts on the part of certain stations to secure the approval of the Federal Office of Experiment Stations to use the Adams fund for economic research were generally unsuccessful. As a result of this limitation of the use in the Hatch and Adams funds and because of the rising interest of the colleges of agriculture in economic and social problems, there was a general demand for additional appropriations which might be used for researches in social science. As a result of this agitation, Congress passed the Purnell Act.

\section{Purnell Act (Approved February 24, 1925)}

The Purnell Act provided the largest federal appropriation in the history of the agricultural experiment stations. The uses of these funds is indicated in Section 1 of the bill: "The funds appropriated pursuant to this act shall be applied only to paying the necessary expenses of conducting investigations or making experiments bearing directly on the production, manufacture, preparation, use, distribution, and marketing of agricultural products and including such scientific researches as have for their purpose the establishment and maintenance of a permanent and efficient agricultural industry, and such economic and sociological investigations as have for their purpose the development and improvement of the rural home and rural life, and for printing and disseminating the results of said researches." This provision of the Purnell Act suggests the broad interest of agriculture. It involves not only the economics of agricultural production but research, intended to solve the problems of rural life and the rural home. The passage of the Purnell Act must be regarded as a new and advanced attack upon at least three new lines of scientific endeavor -agricultural economics, rural sociology, and home economics. Under the provisions of this bill, there has been developed a nation wide interest in the economics of agriculture, in the essentials of a good life in the open country, and large attention to home economics. So great has been the influence of the Purnell Bill upon the policies of agricultural experiment stations that the staffs of these institutions today (1940) as compared with similar organizations under 
the Hatch and Adams laws exhibit a great increase in the number of workers in these new fields. It is interesting to note moreover that coextensive with this development in the agricultural experiment stations, there has been a great increase in the national interest in the broad economic problems of agriculture and in governmental relations to agriculture. The researches in agricultural economics have clearly demonstrated important and fundamental deficiencies particularly in the distribution and marketing of farm commodities.

BANKHEAD-JONES ACT (APPROVED JUNE 29, 1935)

The last law of Congress appropriating additional funds for agricultural research is generally known as the Bankhead-Jones Act. The act itself provides additional funds for each of the important activities of colleges of agriculture-college teaching, agricultural research and agricultural extension. Title 1 of the bill relates exclusively to agricultural research and like each of the other bills describes the limitations of the use of the funds and to some extent indicates the subjects of research. The particular purposes described in the bill which are emphasized are described in Section 1 as follows: "The Secretary of Agriculture is authorized and directed to conduct research into laws and principles underlying basic problems of agriculture in its broadest aspects; research relating to the improvement of the quality of, and the development of new and improved methods of production of, distribution of, and new and extended uses and markets for, agricultural commodities and byproducts and manufactures thereof; and research relating to the conservation, development, and use of land and water resources for agricultural purposes. Research authorized under this section shall be in addition to research provided for under existing law, but both activities shall be conducted by such agencies of the Department of Agriculture as the Secretary may designate or establish." Section 1 , as quoted above, relates primarily to research initiated by the Secretary of Agriculture which is provided by the appropriation of additional funds to the United States Department of Agriculture. Section 2 of the act states further; "The Secretary is also authorized and directed to encourage research similar to that authorized under Section 1 to be conducted by agricultural experiment stations established or which may hereafter be established in pursuance of the Act of March 2, 1887, providing for experiment stations, as amended and supplemented." The provisions of the Bankhead-Jones law emphasize research into the "laws and principles underlying the basic problems of agriculture in its broadest aspects." It also specifically encourages research in marketing and utilization of by-products. The provisions of the bill are undoubtedly influenced by the wide spread interest in conservation since the law provides "research relating to the conservation, development and use of land and water resources for agricultural purposes." It will be seen, therefore, that the Bank- 
head-Jones Bill really provides for an expanding research program which includes the very broad field of conservation of our natural resources as they are related to agriculture.

The development of agricultural research under this legislation has been progressive and competent, and has won the approval of the people engaged in agricultural enterprise. In administering these funds, the directors of agricultural experiment stations have approved projects of current importance as well as many of great fundamental significance. There may be just criticism of some projects of less significance than others but in general and on the whole the agricultural experiment stations have justified the vision of their founders and have accomplished great good.

It may be that the time has come for a re-examination of the experiment station work now in progress with a view to determining whether or not the generous funds available are being expended for the most worthwhile projects. The experience of fifty years of agricultural research certainly has demonstrated that some projects are much more fruitful than others. Some research has been of the greatest importance and value. If the funds available could all be applied to the types of research which have proven of greatest value, it would be a real accomplishment. It would not be easy to classify research now in progress and place some research in Class $A$ and other research in Classes $B$ and $C$, but it is possible from this time forward for directors of agricultural experiment stations to discriminate in approving research projects to the end that there may be the highest and most efficient use of the resources now abundantly available for the service of agriculture.

\section{ACCOMPLISHMENTS OF AGRICULTURAL EXPERIMENT STATIONS}

The passage of the Hatch Act may be said to have been the beginning of the successful development of agricultural education in the United States. It assured the success of the colleges of agriculture and mechanic arts established under the Morrill Act of 1862. The work of these colleges for the first 25 years of their existence satisfied neither the farmer for whom they were established nor the educators who were responsible for their administration. The attempt to teach agriculture was a comparative failure. It was a failure for the reason that there existed no adequate body of knowledge. The literature of agriculture was extremely limited. Such books as existed were in the nature of attempts to record the practices of successful farmers based upon traditional knowledge or in some cases the attempt of chemists to apply the facts of chemistry to the practices of agriculture.

The work of the agricultural experiment stations immediately claimed the interest of scientists, who were concerned with the duty of attempting to solve the problems of agriculture by means of sci- 
entific research. It was during this early period that the farmers' institute had its greatest development. The organization of the knowledge resulting from the researches of experiment stations gradually developed a new literature of agriculture. This literature was based upon science. It was, therefore, reliable. It very gradually changed the attitude of farmers from one of skepticism to one of confidence. With subsequent appropriations and a more efficient organization of these stations, the farmers came to have such confidence in the work that in considering a new method or procedure, their first question often was, "What does the state experiment station think of this plan?"

The farmer has always had a great influence upon the agricultural research of experiment stations. The constant interchange of ideas between the investigators in the experiment station and the farmers on the land has resulted in a wise and understanding attitude on the part of the investigators.

In the beginning, not only the farmer was skeptical of the work of experiment stations but also those scientists not associated with agriculture. There was too much insistence among general scientists that it was sufficient to establish the truth regardless of its value after discovery. The slogans "science for the sake of science" or "knowledge for the sake of knowledge" had too much influence. An attempt was made to distinguish between pure science and applied science to the discredit of agricultural research. Again it must be emphasized that there is no fundamental difference in the quality of research because it is concerned with the solution of problems of agriculture. The difference between pure science and agricultural science is a difference only in motivation. The methods employed are the same. Some of the most fundamental researches being conducted in the United States at the present time are in connection with investigations undertaken to solve agricultural problems. Some of these researches involve the most fundamental phenomena of genetics, of endocrinology, of colloid chemistry, energy metabolism, plant and animal physiology and pathology and many others.

This is not to say that all science is of equal value nor that all agricultural research is fundamental. There is undoubtedly a difference in quality of research whether it be carried on under the name of "pure science" or "applied science". There is some confusion in the use of the term research. It seems somewhat futile to discuss the terms pure science or applied science. This discussion is justified only for the reason that some tendency has been observed to discredit research in applied science because of its purposeful objectivity. One attempt to make distinctions between pure and applied science is reported by the Science Committee of the National Resources Committee in their publication of December, 1938, on governmental research. In this report they say: "The distinction between research in pure and applied science is very difficult to draw. They constantly 
overlap. Perhaps a more intelligible classification is made by Julian Huxley in Science and Social Needs, p. 253. He says: '. . . you would find it impossible to draw any sharp line between pure and applied science.' . . . I am now more than ever convinced that any such line is merely arbitrary, and that often you cannot draw it at all. But, of course, research can be at very different degrees of removal from practice; and it is useful to be able to classify the different kinds of research.

"For that purpose, I have come to the conclusion that the simple alternative of pure versus applied is quite inadequate. You want at least four categories. At one end is background research, with no practical objective consciously in view-like atomic physics, or experimental embryology. Then basic research, which must be quite fundamental, but has some distant practical objective-as is the case with soil science, or meteorology, or animal breeding. Those two categories make up what is usually called "pure research".

"Then you have ad hoc research, with an immediate objective, like research on discharge tubes for lighting purposes, or on mosquitoes for getting rid of malaria. And finally, what industry calls development, or pilot research, which is the work needed to translate laboratory findings into full scale commercial practice.

" 'Of course, these categories all overlap and interlock, but they are convenient pigeonholes." "

It would be a mistake to attempt to discredit any exact scientific research which has for its purpose the establishment of truth. It would be equally unwise to discredit real research in applied science because it is not pure science. Scientific research has placed in the hands of skilled technicians one of the greatest instrumentalities in history for the solutions of the many intricate and complex problems of modern civilization.

With the organization of the Agricultural Extension Service the close relation between the farmer and the experiment station workers became much more important. It was the function of the extension representative to carry directly to the farmer on his own farm the new knowledge of improved farm practices. Incidentally, it was the effective teaching program of the extension service that brought more sharply to the attention of the experiment station the real problems of agriculture. It gave to the station staff a knowledge of the rural problem in its entirety. It was not enough to solve the problem of phosphorus deficiency in the soil and the feed of animals. It was not enough to demonstrate a practical method of treating a particular plant or animal disease. The problem of agriculture was not solved when these important contributions had been made. There was still the problem of the relation of all these to the successful organization and administration of the individual farm. There was the greater problem of the relation of the agricultural industry to all industry, to 
world trade and thus to the whole question involved in the distribution of farm commodities.

The extension worker in direct contact with the farmer brought back to his colleagues in the station the problems of agriculture. The experiment station worker thus came to a knowledge of the whole problem. This relation with farmers has had a great influence on the policies of the experiment stations. It is undoubtedly largely responsible for the widespread popularity and public recognition of these agencies.

Every farmer in the nation has been affected by the work of the state agricultural experiment station. All intelligent, progressive farmers are familiar with the results of experiment station research as applied to their particular interests. The establishment of the experiment station for scientific research as a division of the land grant college gave almost the first important governmental recognition to the value of science in the modern world. This emphasis upon science and research in the development of an industry so basic and fundamental as agriculture is now recognized as one of the most beneficient policies of government.

The growth of the agricultural experiment station has been coextensive with the growth of science. The experiment station has made a great contribution to science itself and to the development of methods, processes, apparatus, and all the essential equipments required for accurate scientific research. More recently the results of the discoveries of agricultural experiment stations have provided a base for important federal legislation for the relief of agriculture. To the extent that these new federal agencies for agricultural improvement are based on the work of the agricultural experiment station, they have been helpful. It must be admitted, however, that some of the work authorized by Congress is more in the nature of wishful thinking than that founded on established fact. Some of these present day national movements for the relief of agriculture are admittedly experimental.

The adjustment of agriculture cannot be accomplished through any process of superficial method or temporary plan. Some of the problems of agriculture are as ancient as man himself. The method of science may be slow but it is sure. We need to have a great expansion of agricultural research along all lines in order that the national policy may be built upon the solid rock of demonstrated truth which comes only from the most painstaking research, by the most competent investigators.

The entire program of the college of agriculture rests on the solid foundation of scientific research. Teaching, experimentation and extension, all owe their present status and past achievements to such research. The contribution of science to agriculture has been thus described by Dr. E. W. Allen, former chief of the Office of Experiment Stations as follows, "Science has been the great basis of progress and 
civilization. There is no more striking example of this fact than in agriculture. During the life of the agricultural colleges there has been more progress in matters relating to farming than in all the centuries that went before."

But science alone is not enough. Increase in knowledge of material things has not and will not by itself insure a permanent civilization. Vast as have been the achievements of science, we have not yet learned fully how to control this Gargantuan instrumentality of human progress.

\section{THE LIMITATIONS OF SCIENCE}

We have clearly come to a time when science, as we have interpreted it, falls short of a complete instrument for social progress. It has made man a little lower than the angels in respect to his dominion over the materials and forces of nature. It has increased man's power immeasurably. Today he rules nature, controls its tremendous forces, and has been responsible for a degree of physical and material progress, during a comparatively short period of time, which transcends the achievements of centuries of effort by primitive man groping for solutions to nature's plan and purpose. For all this progress we must give chief credit to science.

Along with the development of science and the scientific method there has been a quickening of the intellect and a much wider diffusion of knowledge. This notable advance in the intellectual development of the masses has been coextensive with the progress of science. The development of science and intellect have not only solved problems but they have created new ones. With all man's higher intelligence and all the advantages of science as an instrumentality for solving physical and material phenomena, we seem to have been less successful in controlling the results of science and intellect, and utilizing these for the welfare of mankind.

Social progress and human welfare are based primarily on ethics and not on mere dominion over nature. So far we seem not to regard ethics as a part of science. It stands somewhat apart in another realm. Our knowledge of the forces and influences motivating human nature and human behavior is very limited. Science has solved the problems of prevention and control of human disease but not gone very far in preventing or controlling social disorders.

The scientific method has proven its worth. It can be utilized for a study of human behavior. Perhaps the next great advance in science will be social research. The social sciences have already made great progress. Professor Edwin Grant Conklin of Princeton has said, "The ills of society have natural causes and they can be cured similarly by controlling those causes," but he continued "The fact is that social progress has moved so much slower than science that one might say that scientific progress is matched against social stagnation. Many thoughtful persons are asking. Will science which has so largely made our modern civilization end in destroying it?" 
Research in the social sciences is important and must be greatly enlarged but we may well inquire whether after they have added to our knowledge of human behavior and the causes of social unrest we shall not still depend primarily on ethics and the Christian doctrine of the brotherhood of man as a more powerful social control than science or intellect.

The colleges of agriculture owe their great progress and present popularity to their use of science and the scientific method. They have undertaken to apply the methods of science to rural social problems. It is yet too soon to make any pronouncement on their achievements in this field. After all their researches there may still be a need for a more conscious development somewhat outside of the field of science. We may ultimately decide that rural social progress is founded on a basis of ethics. Ethical motives of intelligent humans are essential to a successful social organization.

Whatever of praise, whatever of blame is heaped upon science is sometimes directed toward the work of agricultural experiment stations. One finds it difficult to trace any "social and economic dislocations" directly to agricultural research. It is certainly true that the work of these stations has markedly reduced the costs of production on the average farm. A part of this reduction is from savings in labor costs. The stations are responsible for very great contributions to the conservation of agricultural resources. These contributions are in the nature of conservation of soil fertility, the prevention or control of plant and animal diseases, and improved systems of farming which conserve the heavy labor of the farm and at the same time save the soil. All these conservation measures have resulted in a larger and a better production with a lesser expenditure of labor. But the work of the experiment stations is not to be given full credit for the greater efficiency of farm labor. The actual reduction in human labor required on the farm for each unit of agricultural production is in a large measure due to the much more extended use of improved agricultural machinery. It is probably this latter factor combined with the new knowledge created by the experiment stations which has made it possible for a much smaller rural population to provide the food and fiber requirements of the nation. The extent of this change in agricultural economy throughout the world is revolutionary. It is only on the small peasant farms of Europe and Asia that we still find a great expenditure of human labor per unit of agricultural production.

It does not seem that the problem of unemployment in agriculture will be solved in the United States by going back to hand labor. This is a type associated with the small farm and crowded population. The use of much of the improved agricultural machinery is only profitable on larger farms. Just what the best economic unit may be depends upon the type of farming. 
The displacement of farm labor by machinery has in the past provided the labor for industry. This movement of the surplus agricultural population from agricultural districts to the city should and probably will continue.

It is not yet entirely clear that the great technological progress in industry has after all resulted in unemployment. The great developments in automobile manufacturing, radios, aviation, in electricity, textile, and general labor saving machines have often increased the demand for skilled labor. There is no doubt but that such discoveries and inventions as have reduced the demand for labor on a particular project have resulted in temporary dislocation and require change and adjustment. As Dr. Robert I. Allen, discussing this subject in "Science" says, "The real need, humanly speaking, is for an extension of the methods of science into fields where it is not now applied. . . . No longer should we lay ourselves liable to the charge that the average scientist is too engrossed in the 'pursuit of truth for truth's sake' to consider the impact of his work upon society." This is but another argument for a more complete application of the scientific method to the study of social problems, and to the problem of the social consequences of discovery and invention.

The agricultural experiment station has a broad duty to perform. It is not only to make individual farmers more successful. It is not, as some thoughtless persons have claimed, "to make two blades of grass grow where but one grew before". Its duty is much broader and more important. It has the duty and responsibility of insuring the permanency of agriculture as an industry and the continued well being of rural people. It must accomplish this purpose in such manner as to also serve the public welfare. If this can be accomplishedand it can be and is already being achieved-the agricultural experiment station will justify its national origin and more firmly establish its national destiny. 


\section{PART IV.-THE AGRICULTURAL EXTENSION SERVICE}

Any proper evaluation of the educational influence of the land grant college movement must give due weight to its three major activities,college teaching, research, and extension teaching. The present widespread and enthusiastic approval of these institutions is the result of the intelligent development and successful coordination of this educational triad. The leadership exercised by these institutions is, in the first place, primarily due to the educational program contemplated in the original Morrill Act. As the college of agriculture initiated an entirely new kind of education based upon a different educational philosophy, so the agricultural experiment station and the agricultural extension services were essentially new and ambitious undertakings. There were no federally endowed institutions of higher learning in 1887 providing large scale scientific investigations primarily for the use and benefit of a single industry. There was no nation wide development of extension teaching based primarily upon the practical needs of a great population. The land grant college was a pioneer in the field of a higher education based upon the needs of a single vocation. It was a pioneer in its emphasis upon scientific research as an instrumentality for the solution of the common everyday problems of farm people. It was a pioneer in the organization and administration of a special type of extension teaching, not for college credit but for immediate use in the everyday life of a people.

It is not possible to measure the relative value of these three divisions in the educational movement initiated by the passage of the Morrill Act. We do know that the exceptional development and success of agricultural extension would not be possible without a trained personnel. We are equally certain that without the agricultural experiment station, the educational program of the extension services would soon perish from a drought of ideas. Moreover the technical training in the college is effective because it is solidly based on the work of the agricultural experiment station. It is the research in the stations that makes possible the high type of instruction offered in the college and extension in the field. While the experiment station was provided primarily to solve the problems of agriculture, it is now recognized as essential for good college teaching. The training of leaders in the field of agriculture would be quite inadequate if there were no experiment stations.

But the educational objective of these institutions was not completed by the founding of experiment stations. The Hatch Act for scientific research for the benefit of agriculture, while primarily au- 
thorizing agricultural research, also recognized the importance of disseminating the results of their work. The first paragraph of the Hatch Act provides "That in order to aid in acquiring and diffusing among the people of the United States useful and practical information on subjects connected with agriculture, etc." It was apparent, therefore, that Congress recognized the fact that discoveries for the benefit of agriculture would be of no use unless this knowledge was extended and widely diffused. In the beginning, therefore, many of the workers in colleges of agriculture attempted to extend the knowledge originating in the experiment station to farmers. This was done by attending farmer's institutes, organizing short courses in agriculture and publishing monographs and bulletins. This effort on the part of the college staff only created greater demands and it soon became apparent that there must be a definite well organized agency whose sole duty would be to carry the results of the work of the experiment station directly to the farmers on their own farms. There seemed to have been a general and widespread demand for agricultural extension which undoubtedly resulted from the early efforts of these institutions in extending agricultural knowledge to farm people generally. As a result of this widespread demand, the Congress passed the Smith-Lever Act, providing substantial sums for extension work in Agriculture and Home Economics. There was thus completed the last and final step in the development of Land Grant College education. There was thus provided a thoroughly sound fouryear college education, a highly effective scientific division for solving farmers' problems and a well organized agency for the extension of the practical findings of these stations to the people at large.

When the President of the United States gave his approval to the Smith-Lever Act on May 8, 1914, there came into operation one of the most important educational laws ever enacted by the United States Congress. As in the case of the Morrill Act this law authorized a new type of education not included in the public school program. It recognized government responsibility for adult education to persons beyond the school age. It was a recognition of the economic and social values of the kind of education being taught by the colleges of agriculture. The avowed purpose was education for immediate use on the farms and in the home rather than the improvement and culture of the individual. Culture and improvement would certainly follow but it was to be accomplished by a new kind of educational effort. It was to be an education growing out of the experiences and fundamental needs of rural people, the largest single group in our civilization. Its objective was to improve agriculture, rural life, and the rural home. Here was a new educational plan. It demanded no admission requirements, gave no college credit, insisted upon no artificial standards, had no prerequisites or any of the other conventional mechanisms of academic procedure. It was based upon the real needs of the people; 
it proposed to put knowledge to work. It grew out of a general demand.

The extension of agricultural knowledge began long before the passage of the Smith-Lever law. The first examples were the organization of agricultural societies in several states. As early as 1785 the Philadelphia Society, composed of rural minded members, interested itself in agricultural knowledge. Similar societies were organized in South Carolina, Massachusetts, and Maine. These agricultural societies were, at first, primarily for the benefit of members, but gradually through publications and public addresses they made some effort to extend their benefits to farmers generally. A very important movement began with the organization of the National Grange in 1867. This organization is a national fraternity. One of its purposes is education of rural people. The second step in the progress of agricultural extension was the holding of agricultural fairs. These were often educational and continue to this day to be important educational agencies. The third important development came through the establishment of boards of agriculture by the state governments. It is interesting to know that George Washington in his last message to Congress recommended the establishment of a "Board (of agriculture) charged with collecting and diffusing information." Such a national board was not provided by the federal Congress, but many, perhaps, most states did pass laws resulting in boards of agriculture, one of whose functions was the extension of agricultural information. These boards generally were charged with the conduct of farmer's institutes-the immediate forerunners of agricultural extension services. The farmer's institute was a valuable and popular extension school for farmers. It prepared the way for the great development of agricultural extension services. During the later years of existence it was often administered by the colleges of agriculture. Teachers from the college were often the speakers and the subject matter frequently was based on the results of the investigations of the Experiment Station. It was logical therefore that the institutions should finally become administrators of all agricultural extension.

The passage of the Smith-Lever law nationalized agricultural extension. It made possible a careful evaluation of extension methods. To some extent it came to be an expression of national agricultural policy.

Neither was the enactment of the Smith-Lever law the beginning of extension education by the colleges of agriculture. For many years these colleges had been carrying agricultural knowledge to farmers. The results of agricultural research had been reported to farmers institutes, and other groups. Many colleges organized farmers' weeks at the institution. Some states conducted branch short courses in agriculture, others provided reading courses for farmers and their families. One of the most extensive educational programs was undertaken by Dr. Seaman A. Knapp in the southern states. This 
work was at first financed by the United States Department of Agriculture, supplemented by private donations. Under the name of cooperative demonstration work, important improvement in farm practices resulted. This effort proved so successful that the general education board contributed generously to its support. In 1908 there were employed more than 150 agents in 11 states. By 1910 there were 450 agents at work in 455 counties in 12 states.

The cooperative demonstration work accomplished great good, but it was early apparent that it was not a permanent solution nor entirely satisfactory. It was not conducted by agents thoroughly trained in the state colleges of agriculture. It was not primarily an extension of new knowledge created by the colleges themselves.

With the passage of the Smith-Lever law, this type of education became in truth and in fact an extension of the educational effort of the colleges of agriculture. It was conducted by men trained in the state institutions and thus had a knowledge of local systems of farming, farm practices and methods. Administratively agricultural and home economics extension became decentralized. Its administration was placed in the hands of men thoroughly trained in the agriculture of the region and familiar with local problems.

The impact of the work of the agricultural extension service on the farm practices, intellectual and social life of farm peoples has been very great. It has broadened the vision and developed leadership and self reliance in rural people. The colleges of agriculture have had more than three-fourths of a century in which to perfect their educational processes and methods. The agricultural extension service in contrast has had but little over a quarter of a century of organized effort. Only recently have these services been sufficiently broadened to serve a majority of the farm people of the United States. That this agency has had a profound influence on agriculture, farm people, and rural affairs, generally, is common knowledge. This result was accomplished with a comparatively small personnel in the beginning and a general lack of knowledge and experience in this type of education. If, then, these results have been accomplished in so short a period with limited income and personnel, what may we not expect from the work of these services during the next quarter of a century. It is difficult to avoid superlatives in attempting to describe the accomplishments of these agencies. 


\section{ADULT EDUCATION}

During the Conference on Adult Education held at the University of Missouri in 1934, Dr. Edmond deS. Brunner, professor of education in Teachers College, Columbia University, New York, observed that the agricultural extension service of our colleges of agriculture in cooperation with the federal government and often including the counties is the largest adult educational enterprise in the world. This educational contribution in the field of adult education is not sufficiently recognized or its importance fully appreciated. In 1938 there were more than 11,000 well trained, efficient and successful extension teachers made possible through federal and state appropriations. There is now, 1940, one extension teacher, the county agricultural agent, and often a home economic agent in each one of the counties of the United States. Because of the local situation of these agents, the real problems of every rural community are well known to the administrators of agricultural extension.

In these counties served by extension workers, there were $6,845,558$ farms. On $3,733,584$ of these farms extension workers were responsible for important changes and improvements in farm operation. These changes involved conservation of the soil, improved systems of farming, control of plant and animal diseases, better livestock, improved management of domestic animals and a consequent general economic improvement in the farm community. Nor were farm homes neglected; the county home economics agents report improved home practices in 1,332,950 farm homes. These changes were due to the influence of the extension workers. In carrying out these improvements, home economics agents organized 47,000 farm women's clubs with a membership of more than 1,100,000 in 1938.

The agricultural extension service has made a notable contribution in the direction of developing voluntary local leadership. It is recorded in official reports that more than 800,000 farm men and women became voluntary teachers and leaders of home economic clubs, 4- $\mathrm{H}$ clubs, and other organized agricultural and home economic extension activities.

A purely statistical record is of limited value in determining the essential contributions made by the extension service in advancing the welfare of rural communities. We must dig deeper if we are to discover the real values of this educational movement. We must look for and expect to find better farm homes, better living conditions, better income and a better mental attitude toward agricultural pursuits on the part of rural people. All these have resulted; all these are to be found as a result of agricultural extension activities.

We have in the agricultural and home economics extension project of the colleges of agriculture an outstanding example of what can be done in the general field of adult education. It must, however, be admitted that the success of the extension service in the field of adult education is due to certain important factors. In the first place, it is a 
definite and coordinate division of the college of agriculture and the experiment station. The workers in the field of agricultural extension are college men and women, trained in the field of agxiculture and home economics. They are rural minded. They have a sympathetic attitude toward rural people and rural problems. They are dealing with a subject matter of intense interest and value to the people they are attempting to serve. This subject matter forming the basis of all agricultural and home economics extension teaching is further vitalized by the purposeful, effective and directly usable research of the experiment station. It is based on science. It is new knowledge relating directly to current problems. The teaching techniques are unique. They are often based on a demonstration on the farm or in the farm home. This teaching is not done in a classroom. It does not follow conventional teaching methods. There are no tests, quizzes, or final examinations. The methods employed by agricultural extension and home economics workers have been developed as the result of experience. They have a definite objective, a well defined purpose and this is to carry useful knowledge to farmers and farm women. It is putting knowledge to work. The measure of successful teaching is the improvement of farm and home practices. The system has been remarkably successful as a type of adult education. It must be given an important position in the broad field of educational enterprise in America.

All these developments have been made possible through generous federal and state appropriations and, in many states, the county governments and individual farmers have appropriated funds for this purpose.

\section{ORGANIZATION OF AGRICULTURAL EXTENSION}

The nerve center of the agricultural extension service is in the college of agriculture. It is administered as a cooperative enterprise with the United States Department of Agriculture. The project plans are initiated by the state agricultural extension service. The state extension agents and the county and home demonstration agents are appointed by the state.

The broad policies of the extension service in the states are usually determined by the dean of the college of agriculture. Under the dean is, or should be, the executive head of the extension service. In some states there is a director of agricultural and home economics extension. In some states he is designated as assistant director. In a few states the dean of the college holds the title of director of extension. In every state there is evidence in the organization itself that the policies of the whole institution must be coordinated and unified for efficient results.

Under the director of extension there are usually state agents or assistant directors who are generally supervisors of the county agricultural extension agents. In some cases the supervisor of county 
agents is designated as a county agent leader. Similarly there are home demonstration leaders and $4-\mathrm{H}$ club leaders. In addition to these officials, there are in every state a certain number of extension specialists in soils, animal husbandry, field crops, dairy, poultry, horticulture, entomology, veterinary, agricultural economics, and rural sociology. These specialists are or should be members of the resident departments and, by reason of this connection kept fully conversant with the latest developments and discoveries of the experiment station.

This close organic relation to the resident departments is important in maintaining a closely coordinated and unified agricultural program. In most states, all subject-matter publications must be approved by the department staff concerned. In addition, there are numerous offcial publications of plans and methods of work which are the sole responsibility of the extension staff. This then may be regarded as the typical organized machinery, implemented to obtain certain objectives and insure certain results.

What then are the real objectives of agricultural extension? The federal Smith-Lever Act declares the object to be, "to aid in diffusing among the people of the United States useful and practical information on subjects relating to agriculture and home economics and to encourage the application of the same." Presumably Congress had very definitely in mind the extension of the knowledge discovered by the agricultural experiment stations and the United States Department of Agriculture. In the beginning the major effort seems to have been to extend such knowledge as would help the farmer to increase his income. This is still a major objective, but is by no means the sole purpose. The provisions of the Smith-Lever Act are broad enough to include all information relating to agriculture and home economics. If agriculture is a way of life as well as a business, then the federal law authorizes the extension of knowledge which has for its purpose the establishment of a permanent and prosperous agriculture, and a contented and efficient rural civilization. If we accept this interpretation, then we must conclude that the extension of information relating to community organization, rural health, rural recreation, and all rural affairs are authorized in the federal law.

More and more attention is being given to all those factors in rural life which together insure a good life on the farm. Thus Dr. Arthur $\mathrm{J}$. Klein, in charge of a recent comprehensive survey of land grant colleges has listed the objectives of the agricultural extension service as follows:

"To improve farm earning.

"To improve standards of living.

"To improve social life.

"To develop leadership.

"To develop people. 
"To give opportunity to rural boys and girls.

"To provide vocational training.

"To teach cooperation.

"To improve health and rural life.

"To maintain soil fertility."

This suggests a very broad program of work and a wide opportunity for future development. Dr. C. B. Smith of the United States Extension Staff has described these objectives in a comprehensive statement as follows: "Our large task and the chief objective of extension is increased farm incomes; the building of fine, understanding farm homes; and the development of capable, educated, cultured rural men and women who can do things."

The real objective of all the activities of the college of agriculture, including the extension service, is the establishment in America of a permanent system of agriculture, carried on by an intelligent, competent people with sufficient income to provide a good home and a satisfactory social community. The agricultural extension service, as one arm of the college, occupies a strategic position in accomplishing these objectives. Already we can measure their achievements in many farm communities and in the greater prosperity of individual farmers. The unprejudiced observer can but be impressed with the fact that it is the most intelligent and already efficient farmer who responds to the efforts of the extension service. There still remains a considerable proportion of less intelligent farmers particularly those in the lower economic levels who have not improved their methods, who are not alert to new discoveries and whose social and economic lives have not been influenced at all or but slightly as a result of extension work.

The great need now is to extend its work to include the lower income farmers and by so doing, to raise the general level of agriculture and rural life. However, we must not overlook the very obvious fact that the influence of the better farmers who have profited from the work of the extension service had led indirectly, but no less certainly, to the general improvement of farm practice in the whole community. This means many of the low income farmers are following at least some of the improved methods which may have been first adopted by the more progressive farmers.

The establishment of the Agricultural Extension Service in each of the 48 states just before the beginning of the World War undoubtedly had an influence on the development of this branch of college work. By the time the United States entered the World War, the state extension services were well organized and in a position to serve the nation, particularly in the effort to increase production. As a result of their enterprise, the American people were at no time in peril of deficient food supplies to maintain bodily and mental vigor. There was a very rapid expansion of agricultural extension work during the period 1914 to 1919. Expenditures increased from \$3,600,000 in 1915 to $\$ 14,700,000$ in 1919 . The number of workers in- 
creased to 5,000, made possible by emergency funds provided by federal and state agencies. The service rendered to the nation in this emergency by encouraging conservation of food and clothing, home production in gardens, home nursing during the influenza epidemic of 1918, exchange of goods, aid to draft committees, war loans, and in other ways, is an indication of the availability of this great peace time army in times of emergency. The extension agents have been depended upon in times of drouth, depression, floods and epidemics.

The methods of extension education are original. The farm people themselves are definitely a part of the unified system. The kind of subject matter is in part determined by the expressed needs and desires of rural people. No attempt has been made to impose an education which some outside agency believes farm people ought to have. The farmers are given an opportunity to decide for themselves what is needed. This cooperative relation is accomplished in local communities through voluntary extension committees, farm bureaus, farm clubs or other groups competent to advise what kind of information is most needed. This is an important method and results in decentralizing and localizing all farm extension. It is truly democratic.

The first farm group organized for this purpose was the Farm Bureau of Binghampton, New York. The idea of a farm group cooperating with the extension service grew rapidly and finally was adopted by every state in the Union. The farm organization nationally known as the American Farm Bureau owes its origin to this plan. At first this group was organized solely for educational purposes in cooperation with the federal and state extension services. In recent years the Farm Bureau has included a wide range of cooperative buying and selling, insurance, and legislation. These activities are not authorized by federal law; and while the extension service still cooperates with this organization in extension education, it also cooperates with the Grange, Farmers' Union, farm clubs, or any other representative group which the farmers themselves select for such cooperation.

\section{THE COUNTY AGENT}

There is no one member of the college staff who has received more attention and more favorable support from the people than the county agent. He is the representative in the local farm community of all that the college of agriculture stands for. His primary function and first duty is putting knowledge to work-all knowledge relating to agriculture. Broadly interpreted, this must include an intellectual program far beyond mere physical and material problems concerned with production. It must include economics, sociology, rural health, rural education, recreation, and community organization.

While all these are definitely justified by the legal basis of extension, it has not seemed necessary or wise for the extension service to do more than offer its cooperation to agencies already established and 
functioning in the rural field. Public health services and rural education are departments of government functioning in these fields; and the college of agriculture is for this reason willing and able to cooperate with the activities of these agencies in the rural communities. But, the ultimate goal of all extension work is to insure a good life on the farm; and where other public agencies are unwilling or unable to serve the rural community efficiently in these essential fields, then the agricultural extension staff will eventually be required to render this important service insofar as this can be done by the methods of extension, which means by education. This relation to other agencies is important.

It has come to be quite the universal idea that in order to accomplish any really worthwhile enterprise in the rural community, the promoters or enterprisers must first attempt to secure the cooperation of the county agent. If he can be induced to do the work, its final success is assured.

The county agent seems to be regarded as the chief functionary in his county, dealing strictly with agricultural matters and rural people. He undoubtedly has the confidence of his constituents. His leadership, developed as it has been by his relation to the college of agriculture on one hand and the farmer extension committee on the other, is unquestioned. The county agent is also a representative of the United States Department of Agriculture and as such has come to have a very definite relation to all national movements in any way affecting agriculture. It must be remembered, however, that his function is solely educational. He has no administrative authority. $\mathrm{He}$ may by educational methods explain, clarify and describe all state and government laws relating to agriculture but he may not enforce such laws. Thus, we find the county agent and his office a bureau of information. He is in reality a teacher. He is a leader in a great adult education movement which in magnitude and results is without parallel in the field of public education.

It can readily be concluded that the county agent is overworked. His task is too great for one man. Where, as in some states, he has an adequate staff, the county agent system has come nearer to accomplishing the ultimate purposes contemplated in the federal laws. This task assigned to the colleges of agriculture by the original federal legislation, and generously supplemented by state appropriations, can only be fully accomplished by a further increase of the extension staff. If the significant results, so well achieved during the first twenty-five years of effort, become clearly apparent to all the people, rural and urban, then we shall anticipate that the extension service will be extended and enlarged either by federal or state funds for the very good reason that only by so doing, can the broad purposes, clearly set forth in the federal laws, be accomplished.

While the expansion of the county agent service will undoubtedly result, there is a danger in such expansion to the college of agricul- 
ture itself. Increased appropriations for agricultural and home economics extension may result in disturbing the balance which now exists between the college teaching, the agricultural experiment station, and extension. The extension service owes its very existence to the college and station. Without these efficiently functioning divisions, the extension service may eventually perish from a dearth of ideas. So far extension service has prospered because the personnel are trained in the college and because their whole program is constantly renewed and vitalized by the continuing additions to knowledge and practice flowing out from the experiment station. The future of the extension service itself is dependent on a strong dynamic college and an efficiently organized and directed experiment station. It is false doctrine to assume that agricultural research has been so well accomplished that we may rest on our oars. We need more, not less, agricultural research.

The first county agent in the United States was appointed in Smith County, Texas, in 1906. By 1914 and before the passage of the Smith-Lever law, there were 240 extension agents in 27 northern and western states. The total number of persons engaged in county agricultural extension work in the United States in 1914 was 1350. From the very beginning, demonstration of improved farm practices was a principal method of teaching agriculture to adult farmers. This method was so much more successful than the farmers' institute method of merely describing good practices that it rapidly won the favor and support of farm people and eventually replaced the farmer's institutes as an educational system.

As early as 1908 the Association of American Agricultural Colleges and Experiment Stations officially requested federal funds for agricultural extension. Bills were introduced in Congress in 1909, 1910, 1912 and 1914. The bill finally approved (May 8, 1914), known as the Smith-Lever bill, was the first federal recognition of the present system of agricultural and home economics extension in the United States. The farm demonstration work conducted by the United States Department of Agriculture was not immediately discontinued, but eventually the need for this declined as the agricultural extension enterprise expanded.

The nation-wide organization for agricultural extension in the United States in 1938 was carried on by 6,507 workers. Of this number 4,075 were county agricultural and home demonstration agents serving 2,950 counties. It is estimated that each county and home demonstration agent served directly and indirectly a constituency of 2,000 farmers and farmers' wives and boys and girls. In addition to the regular and normal educational activities of the county agent, he has had a most important educational relation to the national emergency agricultural programs of the Agricultural Adjustment Administration, Soil Conservation Service, Farm Security, Rural 
Electrification, and all other federal plans for the improvement of agriculture.

The efficient administration of agricultural extension education requires measurable results. It is not sufficient to describe improved methods of farm practice. The method is by demonstration. The measure is the number of improved farm practices, actually adopted and used by farmers. Thus in 1938 there were reported 500,000 adult result demonstrations by the farmers themselves under the direction and supervision of the county agents. These improved practices covered the whole field of agriculture from the best systems of soil management, crop and animal production to distribution and marketing.

The county agent is required to keep a record of his activities; and from the more than 4,000 reports made on the work accomplished in nearly 3,000 counties in 1938, M. C. Wilson of the United States Extension Service has compiled the following table.

The Activities and the Number Participated in by the Average County AgRicultural Agent, 1938.

\begin{tabular}{|c|c|c|}
\hline Activities & $\begin{array}{l}\text { Participated } \\
\text { in by all } \\
\text { agents }\end{array}$ & $\begin{array}{c}\text { Approximate Average } \\
\text { Number participated } \\
\text { by each agent }\end{array}$ \\
\hline $\begin{array}{l}\text { Number of } 4-\mathrm{H} \text { judging teams trained } \ldots \ldots \ldots \ldots \ldots \ldots \\
\text { Number of } 4-\mathrm{H} \text { demonstration teans trained } \ldots \ldots \ldots \ldots \\
\text { Groups organized for extension work with rural young }\end{array}$ & $\begin{array}{l}38,827 \\
21,991\end{array}$ & $\begin{array}{l}15 \\
16\end{array}$ \\
\hline 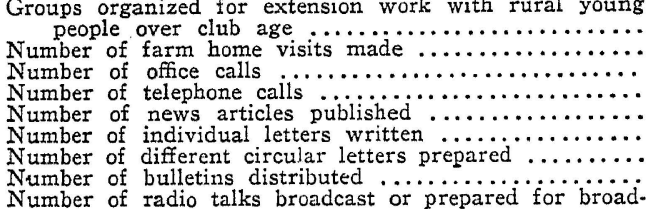 & $\begin{array}{r}1,380 \\
2,024,206 \\
20,695,320 \\
5,419,702 \\
492,804 \\
6,592,816 \\
301,348 \\
7,827,489\end{array}$ & $\begin{array}{r}2 \\
700 \\
7,020 \\
1,868 \\
169 \\
2,202 \\
101 \\
2,705\end{array}$ \\
\hline 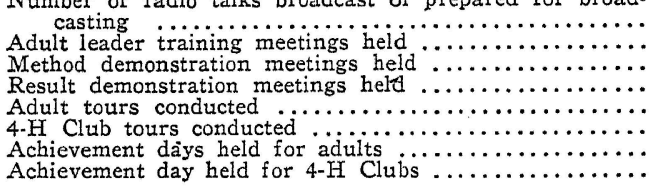 & $\begin{array}{r}12,531 \\
47,435 \\
167,878 \\
51,154 \\
6,564 \\
6,784 \\
2,053 \\
7,183\end{array}$ & $\begin{array}{l}12 \\
18 \\
60 \\
23 \\
3 \\
4 \\
2 x / 2 \\
31 / 2\end{array}$ \\
\hline
\end{tabular}

This is an impressive, not to say amazing, catalog of work. It is valuable also in indicating the means employed to secure these results. The county extension office is a clearing house of agricultural information, but its greatest usefulness would be impossible without the continual supervision of the state agents and technical help of the agricultural experiment station. 


\section{HOME ECONOMICS EXTENSION}

Agriculture as an industry cannot be separated from home building. One of the strongest motives among farm people is the desire for the ownership of a home. But agriculture is almost unique among modern industries in the combination of home and business. When the farmer buys a farm, he buys a home. The two are inseparable. This relation is historic in America. It is not surprising, therefore, that when Congress gave serious consideration to agricultural extension, it also specifically provided for home economics. In any event, so much is the home a part of the farm business that home education would inevitably have been encouraged.

The inclusion of the subject of home economics in the law has undoubtedly aided greatly the very important development of this subject. The actual work of home economics extension is primarily the responsibility of the home demonstration agent located in the county. $\mathrm{Her}$ duties are similar to those of the county agent except that while his activities are chiefly concerned with the business of farming, her work is with farm women and the farm home. Probably no one phase of extension work has made greater or more rapid progress in recent years than has the home demonstration work.

These representatives have made a notable contribution in the field of adult education. More than one million farm women of the United States are now (1940) organized in nearly 50,000 extension clubs. These clubs, meeting regularly for discussion and for acquiring new knowledge on every phase of farm home management, child care, nutrition of the family, house decoration, home canning and preserving, and consumer buying, are now a major extension activity. A mere statistical accounting cannot measure the eager enthusiasm and approval of farm women for this service. The wide reach of this work is only partially indicated by the 1937 report of the United States Extension Service. Included in the results accomplished through the efficient work of 1,789 home demonstration agents, it is recorded that 173,000 farm women made important adjustments in homemaking; 19,000 were guided in remodeling and improving farm homes; 384,000 families were served better balanced meals; 200,000 individual women profited from instruction in textiles and clothing; 107,000 mothers received instruction in child care and participated in parent education; and chiefly through the influence of the home demonstration agents, there were added to the family larder an impressive total of $62,000,000$ quarts of canned fruits, vegetables and meats. The last item has an estimated value of $\$ 18,000,000$.

All the foregoing may be regarded as the physical evidences of a unique type of adult education. It does not record the deeper significance of the whole extension movement. These farm women have discovered a new interest in the common everyday things of life. They better appreciate the dignity of their common occupation. They 
have improved their techniques but they have also added to their store of knowledge. All this sums up to better family relations, better home management, and a definite gain in human happiness.

The American rural home is a cooperative enterprise. Each member of the family is helpful and needed. The American family sized farm home, owned and operated by a farmer and his family is in many respects the most important and permanent social unit in our democracy. Its permanency, and continued progress and development is a matter of public concern. It is clear, therefore, that home economics extension among farm people will become more and more important. The real objective of all farm enterprise is better living in a better home in a better community.

The best expression of the real objectives of home demonstration work is to be found in the report of the Special Committee of the Association of Land Grant Colleges and Universities on Home Demonstration Work printed in the Proceedings of the 52nd (1938) Annual Convention presented by Director I. O. Schaub, chairman of the committee. It is here printed in full.

"Objectives in Home Demonstration Work:

"Home Demonstration work is a part of the national system of extension work in agriculture and home economics developed jointly by the United States Department of Agriculture and the Land-Grant Colleges of Agriculture in the several states and territories. It is a cooperative educational program between these agencies and rural families directed toward the development of the homemaker and improved family and community living. It recognizes that education is a continuing process and that rural homemakers who vary in age, abilities, education and experience, should have educational resources that will help them in meeting the changing conditions out of which arise problems affecting the rural home.

"The fundamental aim of Home Demonstration Work is the development of rural family life in attaining a higher plane of profit, comfort, culture, influence and power through a continuing program of education. It contributes toward self-realization, economic efficiency, assumption of civic responsibility and desirable human relationships.

"Home Demonstration Work is characterized by the rural home and family approach and by the demonstration method in teaching. It stimulates rural people to evaluate conditions in relation to the welfare of the rural family. Out of such evaluation they evolve the current Home Demonstration program, which is designed to solve problems recognized by rural people as of immediate importance to them.

"Home Demonstration Work includes those fields of learning which are generally recognized as of primary importance to the home. It utilizes Home Economics, supplemented by other fields of education. 
"Home Demonstration Work, as determined by needs expressed by rural people includes the following objectives:

"1. To develop desirable standards for home and community living.

“2. To understand and appreciate the function and the relationships of the home in the social order.

"3. To obtain and manage an income, both money and non-money, which will contribute to better living.

"4. To plan and manage both productive and leisure time to the end that energies and resources may best be conserved and utilized and the maximum of satisfaction be gained.

"5. To promote and maintain health.

"6. To discover, develop and utilize leadership, especially among rural women and girls.

"7. To make such personal and family adjustments as are essential for individual and family security.

"8. To develop civic consciousness and willingness to assume responsibility in contributing to the public welfare.

"9. To utilize the results of scientific research in relation to rural home and family life.

"10. To discover and utilize the opportunities and satisfactions which may be derived from rural family life."

The home economics extension work among farm women is in point of results already accomplished and in promise for the future, one of the most important enterprises of the college of agriculture and a notable example of the possibilities in adult education.

\section{THE FINANCIAL BASIS OF AGRICULTURAL AND HOME ECONOMICS EXTENSION}

The federal laws authorizing agricultural and home economics. extension in the several states are known as the Smith-Lever Act, approved May 8, 1914; the Capper-Ketcham Act, approved May 22, 1928; and the Bankhead-Jones Act, approved June 29, 1935. Amendments, approved from time to time, have extended the benefits of this legislation to Alaska, Hawaii, and Puerto Rico. These laws are alike in providing that the funds shall be appropriated to the colleges of agriculture and mechanic arts established under the Morrill Act of 1862 for cooperative agricultural extension. Each requires acceptance by the state legislature and each, except the Bankhead-Jones Act, requires the state to offset the federal appropriation by an equal sum.

The Smith-Lever law provides that the sum of $\$ 10,000$ shall be appropriated to each state without offset. The remaining sum of $\$ 4,100,000$ shall be distributed to the states "in the proportion which the rural population of each state bears to the total rural population of all the states." 
The Capper-Ketcham Act appropriated $\$ 20,000$ annually to each state without offset and the remainder $(\$ 500,000)$ to go to the states in the same manner as provided in the Smith-Lever law.

The latest appropriation bill for agricultural extension is the Bankhead-Jones Act and this provides “(1) $\$ 980,000$ to the several states and territory in Hawaii in equal shares: (2) the remainder shall be paid . . . in the proportion that the farm population of each bears to the total farm population: (3) the several states . . . shall not be required to offset the allotments."

The sums appropriated under the provision of the Bankhead-Jones Act are (1) $\$ 980,000$ divided equally among the states, (2) $\$ 8,000,000$ for the fiscal year beginning July 1 , 1935, (3) $\$ 1,000,000$ additional each year until the total shall have reached $\$ 12,000,000$ authorized to be appropriated annually thereafter. It will be noted that in the later Bankhead-Jones extension law the federal funds are to be distributed to the states on the basis of farm population instead of rural population as required in the Smith-Lever law and that no state off-set is required.

This basis of distribution is more just and equitable, and recognizes the principle that agricultural extension funds should be distributed on the basis of actual farm population rather than the census basis of rural population. The income from the several federal laws and the expenditures within the states for agricultural extension now (1937) reach the impressive total of more than thirty million dollars. Of this amount seventeen million is a direct appropriation by Congress to the land grant colleges and thirteen million is provided by the states, counties, and farmer's organizations. It is significant that the county governments tax themselves to the extent of $\$ 6,330,000$ annually. The voluntary contributions of farmer's organizations amounts to $\$ 800,000$ each year. The state government usually by direct appropriation provides the remaining $\$ 5,870,000$. There is thus an effective federal, state and county cooperation in the support of agricultural extension. The proportion of the cost of extension voluntarily paid by farmer's organizations is decreasing from year to year. After all, this is a public service available to all rural people and is as much entitled to government support as the public school. The voluntary contributions of farmers themselves is eloquent testimony to their appreciation and acceptance of this system.

This variation in the federal laws is to some extent an indication of significant changes in the ratio of farm to urban population. It has not proven difficult of administration. Before the passage of the Bankhead-Jones law, the states were appropriating more for extension than the federal government. In 1935 the states were appropriating in round numbers $\$ 11,500,000$ and the federal government $\$ 9,000,000$. The expenditures for extension based on the cost per person or per farm vary in the several states. In certain New England States as much as $\$ 5.54$ per farm is available from the so-called uni- 
form allotment not requiring offset. The average for all the United States is only 35 cents per farm from the same source. The proportion of the cost of extension supplied by the state varies. In North Dakota it is 1 per cent; in Washington, 3 per cent; in Connecticut, 37 per cent; and California, 38 per cent. There are 13 states which appropriate more than 25 per cent. These figures are for 1937.

The much discussed offset or matching requirement of Congress seems, in general, to have been unnecessary if its purpose was to influence states to increase their appropriations. Undoubtedly it did influence some states, but the fact that states generally, before the depression, appropriated more for extension than the federal government is some evidence that the states have not been content to depend entirely on the federal government for support of this service. The distribution of costs of the county and home demonstration agents between federal, state and county funds varies. The salaries of county extension agents are in some states paid in part by the county government. Usually all local expenses are supplied by the county. In other states the entire salary of county workers is paid from federal and state funds and the local expenses are paid by the county. This seems to be the goal toward which most states are now working. It must be said, however, that substantial local support does furnish a certain local interest that is desirable.

\section{THE 4-H CLUBS}

Probably no one enterprise of the extension service has received so much favorable attention and approval as $4 \mathrm{H}$-club work with farm boys and girls. The Smith-Lever Act required the diffusion of knowledge relating to agriculture and its application. Congress did not undertake to suggest the methods to be followed. The first method was to carry this knowledge to the farmer. This was notably successful, but it was soon everywhere apparent that the farm home must be included in this diffusion of knowledge. And so, there was developed the wide-spread and effective home demonstration enterprise, which intelligently coordinated with the county agent work, soon developed into a major extension project. But the development of agriculture as a way of life as well as a business could not ignore the welfare of the farm family, including the farm boys and girls. Thus, the final step in group action was the organization of boys' and girls' clubs. The wisdom of this method of extending knowledge has been fully justified by experience.

The agricultural extension service is responsible for the form and widespread success of the 4-H club project. True, the idea of organizing rural boys and girls around some farm and home project was early undertaken in Illinois, Iowa, and Ohio.

In 1908 Dr. Seaman A. Knapp organized the boys' and girls' club work with the aid of funds supplied by the General Education Board 
of the Rockefeller Foundation. The objects of these clubs as then stated were:

(1) "To place before the boy, the family, and the community in general an example of crop production under modern scientific methods.

(2) "To prove to the boy, his father, and the community generally that there is more in the soil than the farmer has even gotten out of it; to inspire the boy with the love of the land by showing him how he can get wealth out of it by tilling it in a better way and keeping an expense account of his undertaking.

(3) "To give the boys definite, worthy purposes at an important period in their lives and to stimulate a friendly rivalry among them.

(4) "To furnish an actual field example in crop production that will be useful to rural school teachers in vitalizing the work of the school and correlating the teaching of agriculture with actual practice."

These objects embodied the leading purposes of the boys' club movement in the beginning. It was, however, not until 1914 and after the organization of the state agricultural extension services that club work became a significant part of the extension program. At the present time (1940) there is, perhaps, no other extension effort which has enlisted the interest and cooperation of so many farm organizations, farmers' institutes, state boards of agriculture, public schools, state fairs, commercial and industrial organizations, railroads, newspapers, and farm papers, as has the 4- $\mathrm{H}$ club enterprise.

In the beginning this project was designated 'Boys' and Girls' Club Work", but about 1911 the emblem was changed to symbolize a four leaf clover; one leaf representing the head, another the heart, a third the hand, and the fourth health. The name of these clubs was changed to " $4-\mathrm{H}$ Clubs" in recognition of this symbolic emblem.

A statistical analysis of the $4-\mathrm{H}$ clubs, taken by itself, has little meaning but when considered with the known record of these nationwide groups, the results are impressive. In 1939 there were more than 1,000,000 rural boys and girls in 74,594 organized clubs actually working on 1,500,000 projects involving improved farm and home practices. These clubs were guided not only by county, home demonstration, and club agents but by 143,017 voluntary leaders. So successful is this form of extension education that clubs have been organized in 3,000 counties of the United States. It is reported in Extension Circular 312 of the United States Department of Agriculture that more than 45 per cent of all farm boys and girls in the United States are now being reached by $4-\mathrm{H}$ club work. Since the passage of the Smith-Lever Act more than 7,500,000 boys and girls have been active members of 4-H clubs. In 1915-1919 there were reported 300,000 club members while in 1935-1938 there were $1,155,000$ individuals working under competent local leadership and supervised by trained college men and women in the extension service. 
The great importance of any national program of rural youth education is fully recognized by the leaders of $4-\mathrm{H}$ clubs. The real objectives of $4-\mathrm{H}$ club work have been given intelligent consideration by committees of the Association of Land Grant Colleges and Universities. These committees are in substantial agreement upon the objectives of rural youth education by means of $4-\mathrm{H}$ clubs. These are to encourage desirable ideals and standards for farming, home making and citizenship, to teach good farm and home practices, to "learn to do by doing"; to inculcate habits of healthful living, arouse worthy ambition, to better appreciate the values of rural living, and all this as a means to the development of habits of integrity, industry and a good life in a rural environment.

Attempts have been made to evaluate the educational results of the 4-H club movement. Such evaluation is difficult for the reason that the substantial results in character building, self-reliance and better appreciation of rural values are intangible qualities. The development of these qualities is, after all, the major objective. The projects themselves are means to an end. The increased knowledge and skills would in themselves be worthwhile objects, but this development is directly associated with and responsible for those qualities of "head and heart" which make for a better life. There is no youth problem among the members of the 4-H clubs. It is a well known fact that all children born in the rural community will not be able to find opportunity there, either for employment or a chance for individual ownership; at least as agriculture is now organized. The 4-H clubs may be developing new rural industries and new uses for land which will encourage rural minded youths to remain in the open country. If so, it will be a major contribution to our present (1940) social and economic problems.

The widespread interest in the growth and progress of the 4- $\mathrm{H}$ club movement has influenced many great corporations, farm organizations, railroads and chambers of commerce to provide substantial prizes and awards for encouraging this educational movement. In the main, these have stimulated rural youth to greater excellence and have been generally approved by the $4-\mathrm{H}$ club leaders.

In a few instances there has been some evidence of an attempt to commercialize this plan of prize giving, but where this happens, it has been promptly corrected. The educational values in the 4-H club project do not require this kind of artificial stimulus and any attempt of this character should be immediately discouraged. The Committee on Extension Organization and Policy of the American Association of Land Grant Colleges and Universities has recommended the following principles governing awards and prizes:

(1). "In so far as possible, such prizes should be awarded so as to encourage future development on the part of the one receiving the prize, such, for example, as scholarships, educational trips, etc. 
(2). "The value of cash or material prizes or awards should not be incommensurate with the efforts expended.

(3). "Prizes for the club group as a group should be encouraged.

(4). "All forms and records used should be prepared or approved by the State Extension Service and should carry no objectionable advertising.

(5). "Prizes or awards should not be accepted which specify that any particular brand of material, equipment or supplies be used in the project.

(6). "A roster of club members should not be furnished any one for any purpose.

(7). "All prizes or awards offered on a regional or national basis should first be presented to the Extension Committee on Organization and Policy for suggestions and approved before being presented to the states.

(8). "All initial announcements of prizes and awards should be made through the State Extension Service."

It must be admitted that most agencies and individuals responsible for awards to $4-\mathrm{H}$ club members are influenced primarily by the intrinsic value of the type of work being accomplished by these clubs and not by selfish motives. There is evidence that every effort is being made by club leaders to prevent the exploitation of farm boys and girls. A warning about offering prizes of too great value has been made by the President's Advisory Committee in the following terms:

"It has been inevitable that 4-H club work should occupy a prominent place in the mouthpieces of publicity. The publicity value attendant on the club work has undoubtedly been a factor in interesting commercial groups and organizations in offering prizes, but not infrequently the prizes are so valuable that winning becomes more important than the learning that should accompany the activity. Competition, instead of serving as a motivating device, becomes paramount; unethical practices creep in; jealousies result; and more harm than good comes from the outside support."

This pronouncement by the President's Advisory Committee is to be regarded more in the nature of a possible danger than of any condition which actually exists. Those primarily responsible for 4- $\mathrm{H}$ club work know very well that the generous contributions made by farmers' organizations, chambers of commerce, railroads and business firms are based upon the intrinsic values from the club work rather than the publicity which they receive.

The report of the President's Advisory Committee has raised some fundamental questions relating to $4-\mathrm{H}$ club work. The report includes the following statement: 
"There has been a growing recognition on the part of school administrators and teachers of the value of having children participate in the practical work of the general character of the 4-H club work. The present organization of school children in 4-H clubs thus has a tendency to cut the schools off from a very much needed curriculum element. From the point of view of sound educational procedure, the present 4- $\mathrm{H}$ club is too narrowly conceived, in spite of the tendency of recent years to broaden it. The practical activities conducted by children in their clubs should have their setting in the matrix of general education that can be most economically and effectively supplied by the schools. The present policy points too largely to the development of another educational system paralleling and duplicating what the school system should be doing for rural children."

The inference from this quotation seems to be that the 4-H club movement should be a part of the public school program. One objection to such change in the administrative responsibility for this project is that the real motive in all agricultural extension, including $4-\mathrm{H}$ club work, is the welfare of agriculture, the farm family and rural life. Education based on the ordinary everyday interests of farm people as developed by the agricultural extension services has proven its value. It is by no means certain that the character of 4-H club work would be retained if organized in the school system. It is, of course, unfortunate that rural school education has not recognized the fundamental importance of rural education in terms of rural affairs. A decision on this matter should be based not upon the welfare of the school system but upon the best interests of rural people. It is not at all impossible for the club work, organized and directed by the agricultural extension service, to be so intimately correlated with the school activities that it will retain the important supervision it now has and at the same time contribute to the upbuilding of the rural school system. 


$$
\text { , }
$$




\section{CONCLUSION}

It was Thomas Jefferson, the founder of the University of Virginia, who wrote that the real objective of education is "to give every citizen the information he needs for the transaction of his business." More and more all higher education attempts to justify itself on the grounds of training for citizenship, the improvement of the individual, and by this means the improvement of society. The means to this end and the methods to be employed are matters about which there is a substantial difference of opinion. The land grant college and university, and particularly the college of agriculture, has demonstrated beyond all question that it is possible to educate men and women for successful achievement in rural affairs. Opposed in the beginning by almost the entire educational fraternity and still not accepted into full fellowship with the older disciplines which still insist that liberal culture is the surest and best preparation for citizenship, these institutions have nevertheless held rigidly to their purposes and have really demonstrated that an education based on the needs of a great industry is also worthy. There is no question as to the high value of liberal culture to any man. There is no longer any question as to the high value of a technical training for a specific vocation or way of life.

The great development of special training courses in engineering, journalism, education, fine arts, and agriculture in the present-day colleges and universities is sufficient evidence that such courses now occupy a major position in all the leading colleges and universities of the land. This development is in part due to the successful experiment of the colleges of agriculture. Opposed in the beginning as they were, not only by the leaders of education but by the farm people themselves, they have come to a position of influence and power among institutions of higher learning in the United States. These colleges of agriculture have developed institutions solidly based on the needs of agriculture and rural life. They have emphasized utility in education. They have had a large part in the gradual shift of educational effort from the ideal of scholasticism to that of humanism. They have been a chief influence in democratizing higher education. They have made a real contribution to higher education in demonstrating to the public generally that a college education is worthwhile as a preparation for the business of life.

These colleges are frankly vocational. But this does not mean any lowering of intellectual standards. The graduate school itself is quite as much vocational. Indeed the college of agriculture with its research division represented by the agricultural experiment station is today exceptionally well prepared to cooperate with the graduate 
school in the training of men and women for the most advanced services where high intellectual attainment is required. Their contributions to knowledge and leadership in rural affairs has led to a much clearer understanding of the rural problem. They have made the farmer more prosperous. They have provided an intellectual life for farm people. The literature of agriculture today is the literature of the college of agriculture. The future of agriculture in America is intimately bound up in the continued growth and prosperity of the colleges of agriculture.

The agricultural experiment station has emphasized the value of science as an instrumentality for the successful solution of the problems of agriculture. "Science for the sake of science" is not a principal motive in agricultural research. The experiment station has revolutionized the attitudes of farm people toward the practical values of scientific research in the modern world. From an attitude of suspicion and even antagonism toward science, these agencies have won the enthusiastic support and approval of farmers, the most conservative element in our democracy; and along with this, the approval and support of the public generally. They have popularized science not by any super-publicity methods but by utilizing science as an instrument to solve the intricate and difficult problems of agriculture. This has been a real contribution to all science.

Through the agricultural and home economics extension service, the college of agriculture has made it clear that the influence of an institution of higher learning may extend far beyond the limits of the college campus. The program of adult education, intelligently organized and efficiently administered, has influenced more adult people and changed more practices than any similar educational movement in all history.

The notable progress of the college of agriculture is, in large part, due to the completeness of its educational plan. The college education prepares young men and women for successful achievement in rural affairs; the agricultural experiment station utilizes the methods of science for adding constantly to our store of knowledge relating to agriculture; and the agricultural and home economics extension service has assumed the responsibility of educating the farmer and his family by extending the influence of the college to all engaged in agricultural enterprise. This triad of education has made the college of agriculture what it is and is an important factor in the wide-spread approval of these institutions.

It may well be that when the history of the colleges of agriculture is finally written, their substantial and enduring contribution will be a significant improvement in every phase of rural life and especially the rural community and the rural home. If it be so, then it will be also a great contribution to the national welfare. 